\begin{tabular}{|c|c|c|c|}
\hline Article Info & \multicolumn{2}{|c|}{ RESEARCH ARTICLE $\quad$ ARAŞTIRMA MAKALESI } & \\
\hline Title of Article & \multicolumn{2}{|c|}{$\begin{array}{l}\text { The Effects of Cultural Values on Urban } \\
\text { Identity in Neighbourhood Scale: Kale } \\
\text { Neighbourhood-Samsun }\end{array}$} & \\
\hline $\begin{array}{l}\text { Corresponding } \\
\text { Author }\end{array}$ & \multicolumn{2}{|c|}{$\begin{array}{l}\text { Birnur KÖSE } \\
\text { Karabük Üniversitesi Lisansüstü Eğitim Enstitüsü, Mimarlık Anabilim Dalı, } \\
\text { birnur.kose@ hotmail.com }\end{array}$} & \\
\hline $\begin{array}{l}\text { Received Date } \\
\text { Accepted Date }\end{array}$ & \multicolumn{2}{|l|}{$\begin{array}{l}21.06 .2021 \\
21.12 .2021\end{array}$} & \\
\hline DOI Number & \multicolumn{2}{|c|}{ https://doi.org/10.35674/kent.955281 } & \\
\hline Author / Authors & $\begin{array}{l}\text { Birnur KÖSE } \\
\text { Yasin DÖNMEZ }\end{array}$ & $\begin{array}{l}\text { ORCID: 0000-0003-2881-3735 } \\
\text { ORCID: 0000-0003-2840-6312 }\end{array}$ & \\
\hline How to Cite & \multicolumn{2}{|c|}{$\begin{array}{l}\text { KÖSE, B., DÖNMEZ, Y., (2021). Mahalle Ölçeğinde Kültürel Değerlerin Kent } \\
\text { Kimliğine Etkileri: Kale Mahallesi-Samsun, Kent Akademisi, Pages, 1156-1190. }\end{array}$} & $\begin{array}{l}\text { Kent Akademisi } \\
\text { Urban Academy }\end{array}$ \\
\hline
\end{tabular}

\title{
Mahalle Ölçeğinde Kültürel Değerlerin Kent Kimliğine Etkileri: Kale Mahallesi-Samsun
}

\begin{abstract}
:
Cities, which have an important place from past to present with their features, are in a continuous development and transformation. Cities, which have different culture, historical past and different features within the developmental process, have unique values in this respect. These values show the unique identity of the city. Urban identity, which is formed by the accumulation of tangible and intangible values within the historical process, is evaluated under various components and these components also become the subject of many researches. This study was shaped in line with the determination of the effects of the cultural values of cities on the urban identity and for this purpose, the concepts of urban identity and urban culture and the relationship between these were examined. In terms of revealing the effects of cultural values on urban identity, Kale neighbourhood, a historical industrial centre which is one of the oldest settlement areas of Samsun province, which has a long history and which is also an important port city, has been determined as the study area. It is thought that the study will create awareness by revealing the effects of cultural values on creating urban identity and by emphasizing the values that have become the symbol of the city and form the identity of Samsun province in line with the example of Samsun Kale neighbourhood.
\end{abstract}

KEYWORDS: Urban identity, Urban culture, Cultural values, Samsun, Kale Neighbourhood

ÖZ:

Sahip oldukları özelliklerle geçmişten günümüze önemli bir yerde olan kentler, sürekli bir gelişim ve dönüşüm içerisindedir. Gelişim süreci içerisinde farklı kültür, tarihsel geçmiş ve farklı fiziksel özellikler barındıran kentler, bu açıdan kendine özgü değerler taşımaktadır. Bu değerlerde kentin özgün kimliğini ortaya koymaktadır. Tarihsel süreç içerisinde somut ve somut olmayan değerler birikimi ile oluşan kent kimliği, çeşitli bileşenler altında değerlendirilmekte

${ }^{1}$ Karabük Üniversitesi Lisansüstü Eğitim Enstitüsü, Mimarlık Anabilim Dalı, birnur.kose@hotmail.com

2 Doç. Dr., Karabük Üniversitesi, Mimarlık Fakültesi, Peyzaj Mimarlığı Bölümü, yasindonmez@karabuk.edu.tr 
ve bu bileşenler birçok araştırmaya da konu olmaktadır. Bu çalışma kentlerin sahip olduğu kültürel değerlerin kent kimliğine olan etkilerinin belirlenmesi doğrultusunda şekillenmiştir ve bu amaçla kent kimliği ve kent kültürü kavramları ve aralarındaki ilişki irdelenmiştir. Kültürel değerlerin kent kimliği üzerindeki etkilerinin ortaya konulması açısından uzun bir tarihi geçmişe sahip aynı zamanda önemli liman kentlerinden biri olan Samsun kentinin en eski yerleşim bölgelerinden, tarihi ticari merkez niteliğindeki Kale Mahallesi çalışma alanı olarak belirlenmiştir. Çalışmanın kültürel değerlerin, kent kimliğinin oluşmasındaki etkilerinin ortaya çıkarılmasında ve verilen Samsun Kale Mahallesi örneği doğrultusunda Samsun kentinin kimliğini oluşturan, kentin simgesi haline gelmiş değerlerini vurgulayarak farkındalık kazandıracağı düşünülmektedir.

ANAHTAR KELIMELER: Kent kimliği, Kent kültürü, Kültürel değerler, Samsun, Kale Mahallesi

\section{GíRiş:}

Süreç içerisinde gelişim gösteren dünya ile birlikte kentlerinde gelişim gösteriyor olmasından dolayı sürekli değişen ve dönüşen kent kavramı tarihin her döneminde farklı tanımlanmıştır ve çok sayıda çalışmaya konu olmuştur. Kentler hem fiziksel hem de kültürel özellikleri ile tarihsel süreçte önemini yitirmemiş ve küreselleşen dünya ile birlikte daha da önem kazanmıştır. Kentte yaşayan bireylerin yaşam biçimleri doğrultusunda ortaya çıkan ihtiyaçlar ile şekillenen kentler, bu bağlamda içinde bulundurdukları toplum ile bir bütündür. Bu açıdan içinde bulundurdukları toplumların olumlu veya olumsuz tüm özelliklerini taşıyan kentler insan ilişkilerini ve toplum yaşamını şekillendirmişlerdir (Koçak, 2011; Öztürk vd., 2021). İnsan ilişkilerinin ön planda olduğu kültürel, siyasal ve sosyal yerleşim alanı olan kentler sahip olduğu toplumsal ve kültürel değerler birikimi ile kendine özgü bir kimlik oluştururlar ve oluşturdukları bu özgün kent kimlikleri ile birbirlerinden farklılık gösterirler. Yaşanabilir alanlar oluşturulmasında ve insanların yaşadıkları alanlara olan aidiyet duygusunun arttırılmasında kimlik kavramının rolü büyüktür (Günaydın ve Altunkasa, 2019). Kent kimliği, kentin tanımlanmasını ve ayırt edilmesini sağlayan özelliklerinin bir bütünüdür (Ünügür, 1996). Kent kimliği kentlerin kendine özgü değerler birikimiyle uzun bir süreç içerisinde oluşmaktadır ve bu süreçte yaşanan gelişim ve dönüşümlerden dolayı dinamik bir kavramdır (Kaypak, 2010).Kent kimliği, kentin geçmişten günümüze özgün özelliklerini aktaran, kültürel, sosyo-ekonomik, fiziksel, biçimsel ve tarihsel özelliklerle şekillenen (Kösoğlu, 1995; Ayyıldız ve Ertürk, 2017), kentte yaşayan bireyler ve bu bireylerin yaşam şekillerinin birikimi ile oluşan (Çöl Demirseren, 1998; Erdoğan ve Akay Çorbacıŏglu, 2018) ve bu doğrultuda değişim ve gelişim gösteren kavram olarak da açıklanabilir. Kısaca kentin sahip olduğu çevresel özellikler (doğal özellikler ve içinde barındırdıkları toplum tarafından ihtiyaçlar doğrultusunda oluşturulan yapay özellikler) ve toplumsal özellikler (toplumun taşıdığı kültürel, ekonomik ve psikolojik özellikler) zaman içerisinde kent kimliğini oluşturur ve kentin temel niteliklerini gelecek kuşaklara aktarır.

Kent kimliğinin oluşumunda en önemli etkenlerden biri kent kültürüdür. Kent kültürü; kentin barındırdığı insanlar tarafından, ortak bir noktada oluşturulan somut veya soyut değerlerin ortaya çıkış sürecidir (Hayta, 2016). Bir kentin kimliğini oluşturan onun kültür varlığı; kültürüne katkıda bulunan da kentin kimliğidir (Keleş, 2007). Bu açıdan bakıldığında kent kültürünün kent kimliğinin temelini oluşturduğu görülür (Güler vd., 2016; Öztürk vd., 2018c). Kentler zaman içerisinde geçirdiği değişimler sonucunda kent kimliğinin oluşumunda önemli rol oynayan kültürel değerlerini kaybedebilir. Bunun bir sonucu olarak kentler onları diğerlerinden ayıran özgünlüklerini de yitirmiş olur. Kent kimliğinin korunabilmesi, kentin sahip olduğu bu kültürel değerlerin gelecek nesillere aktarılması yani devamlılı̆̆ ile mümkündür (Alevkayalı ve Uzun, 2020). Bu noktada kentin barındırdığı toplumun duyarlılığı önemli bir yerdedir.

Toplum yaşadığı kentle bütünleşmeli ve kent kimliğinin oluşumunda önemli rol oynayan kültürel değerler korunarak kentlerin birbirleriyle benzer hale gelmesi engellenmelidir. Kentlerin sahip olduğu değerleri korumak ve geleceğe aktarabilmek açısından yapılan dönüşümlerin olumlu ya da olumsuz yanlarının iyi tespit edilmesi gerekmekte ve uygulamalar kentin sahip olduğu değerlere zararın en az olacağı şekilde yapılmalıdır (Kaypak, 2010; Öztürk vd., 2020a).

Uzun bir geçmişe sahip olan tarihi kentler, kent kimliğinin oluşumunu etkileyen tarihi dokuları ve eski dönemleri yansıtmalarıyla önem taşımaktadır (Oğurlu, 2014). Bu nedenle geçmişle gelecek arasındaki ilişkinin korunması açısından önemli olan, geçmişe ışıı tutan tarihi kentlerde yapılan dönüşümler daha da önem taşımaktadır (Abou Ouf ve Makram, 2019). Geçmişi çözümleme ve geleceği doğru şekillendirmede önemli bir yerde olan tarihi kentlerin sahip olduğu eserler, bir toplumun geçmişten günümüze biriktirdiği kültürün somut bir yansımasıdır. Tarihi dokuya sahip kentlere yönelik oluşan koruma kavramı, başlarda yalnızca bu somut eserlere yönelik iken günümüzde koruma kavramı kenti farklı kılan özellikleri ortaya çıkartmak, kentin geçmişini yansıtarak devam ettirmek olarak benimsenmektedir (Dönmez vd., 2017). Toplum duyarlılığı ile kentin tarihi dokusunu koruyarak kenti dönüştürmek ve kentin sahip olduğu 
somut ve soyut kültürel değerleri oluşturulmuş olan ilgili birimlerinde desteğiyle koruyarak günümüze aktarmak çok önemlidir (Sezik, 2018). Bu konuda çalışma kapsamında tarihi ve kültürel geçmişiyle önemli bir yerde olan Samsun kenti ele alınmıştır.

Samsun kenti geçmiş çağlara uzanan çok sayıda farklı uygarlıkları ağırlamıştır. Tarihsel süreç içerisinde duraklamalar yaşamış ancak önemini yitirmemiş ve gelişerek günümüze ulaşmıştır. Aynı zamanda kent hem coğrafi konumu hem de sahip olduğu tarihsel geçmişi açısından önemli bir yerdedir (Yılmaz, 2011). Samsun kenti, tarihsel süreçte kimliğini de etkileyecek çeşitli tarihi olaylar yaşamıştır ve tarihsel bir birikim sonucunda oluşan bu somut ve soyut kültürel değerlerini günümüze taşımıştır (Yılmaz ve Gül, 2018).

Bu çalışma konumu ve sahip olduğu tarihi özelliklerinden dolayı Samsun kentinin kültürel değerlerinin Kale Mahallesi örneği üzerinden kent kimliğine olan etkilerinin belirlenmesini araştırmak amacıyla yapılmıştır. Kent kimliği konusunda yapılan çok sayıda araştırmaların olduğu (Alevkayalı ve Uzun, 2020; Sağlık ve Kelkit, 2019; Erdoğan ve Çorbacıoğlu Akay, 2018; Güler vd., 2016; Kaypak, 2010; Kodal ve Demirel, 2014; Koyuncu, 2013) ancak Samsun Kale Mahallesinin kültürel değerlerini kent kimliği bağlamında ortaya koyan akademik ve uygulamaya yönelik yapılmış herhangi bir çalışma bulunmadığından yapılan çalışma Samsun kenti örneğinde kimlik bileşenlerinin irdelenmesi açısından önem taşımaktadır.

\section{KENT KIMLLIĞİ VE KÜLTÜREL DEĞERLERİN İLIŞKİSi}

Kentler, tarihi süreç içerisindeki kültürel, sosyal ve fiziksel özelliklerin birikimi sonucunda oluşan sosyal ve fiziksel alanlardır (Birol, 2007). Sürekli bir değişim ve dönüşüm içerisinde olan kentler, küreselleşme ile birlikte tekrar gündeme gelmiş ve daha da ön plana çıkmıştır (Öztürk vd., 2018a; Öztürk vd.,2018b). Çeşitli şekillerde tanımlanan kent kavramı genel olarak, kırsal alanları da dahil edebileceğimiz, içinde bulunan insanların birbirleriyle olan ilişkilerini ve yaşam tarzlarını biçimlendirdiği, devamlı bir üretim ve tüketimin olduğu mekanlar olarak tanımlanmaktadır (Hayta, 2016). Toplumun birbirleriyle olan ilişkilerini ve yaşam tarzını şekillendiren kentler, geçmişten günümüze olan süreç içerisinde kazandıkları değerler birikimi ile kendilerine has kent kimliği ve kent kültürü oluşturmuşlardır.

Günümüzde kentleri birbirinden farklı kılan özelliklerin korunması, ön plana çıkarılması önemli hale gelmiş ve bunun sonucunda kent kimliği, kent kültürü gibi kavramlar yeniden önem kazanmıştır. İnsanlar arasındaki iletişimi, sosyal ve kültürel değişimleri kapsayan, fiziksel ve kültürel etkileşim alanları olan kentler, bunun gibi çeşitli kavramlarla birlikte anlam kazanır. Bu açıdan kentler bir birikim süreci sonucunda oluşan alanlar olarak değerlendirildiğinde kent kimliği ve kent kültürü kavramlarını ve aralarındaki ilişkiyi doğru algılamak çok önemlidir. (Güler vd., 2016).

\subsection{Kent Kimliği}

Kimlik kavramı insanın tanımlanması ve sahip olduğu özellikleri içermesinin yanı sıra kentlerinde tanımlanması ve özelliklerini içeren bir kavramdır (Aktaş, 2016). Kent kimliği, kentleri birbirinden ayıran tüm özellikleri içeren ve kentleri tanımlamada kullanılan en önemli etmendir. Kent kimliği, kentlerin süreç içerisindeki değerler birikimi ve kentin barındırdığı toplumun yaşam şekilleri doğrultusunda oluşan ve farklı dönemlerde farklı şekillerde tanımlanan, kent kavramına göre kendini değiştiren ve dönüştüren dinamik bir kavram olarak tanımlanabilir (Kaypak, 2010). Özetle kent kimliği kenti diğerlerinden farklı kılan öz yapısını ifade eder (Boussaa, 2017). Kentlerin coğrafi durumu, kentli nüfusun yaşam tarzı, gelenek ve görenekleri, kültürel yapısı yani maddi ve manevi tüm öğeler kent kimliğini oluşturan unsurlardandır. Bu unsurlar bir kenti diğerlerinden farklı kılar ve özgün bir kimlik oluşturur (Oğan ve Yasak, 2020). Aynı zamanda kentin kimliği kentte yaşayan bireylerin kentte bulduğu değerlerin bütününü kapsar (Tekeli, 1991: 8182).

Kent kimliği çevrenin barındırdığı yapay ve doğal özellikler (Kodal ve Demirel, 2014), toplumsal ve kültürel değerler (Güler ve ark, 2016), kültürel-tarihsel birikim (Kiper, 2006), sosyo-ekonomik, fiziksel ve biçimsel etmenlerle (lynch, 1961) biçimlenen ve kentteki bireylerin yaşam tarzlarının ortaya çıkardığı bütündür (Erdoğan ve Çorbacıoğlu Akay, 2018). Kent kimliğini oluşturan bileşenler çevresel kimlik ve toplumsal kimlik kavramları üzerinden açıklanabilir. Doğal çevre bileşenleri; topoğrafik özellikler, iklim ve bitki örtüsü kategorisinden oluşmaktadır. Yapay çevre bileşenleri; yerleşim ve kentin sembolü olmuş öğeler gibi özellikleridir. Toplumsal kimlik bileşenleri; demografik yapı, kültürel ve tarihsel özelliklerini içine alan sosyo-kültürel çevre, kentin işlevsel özelliklerini kapsayan sosyo-ekonomik özellikler ve gastronomi, kültür-sanat, folklor, yaşam tarzı özelliklerini içeren somut olmayan kimlik faktörlerinin bütünüdür [Şekil 1] (Kodal ve Demirel, 2014). 


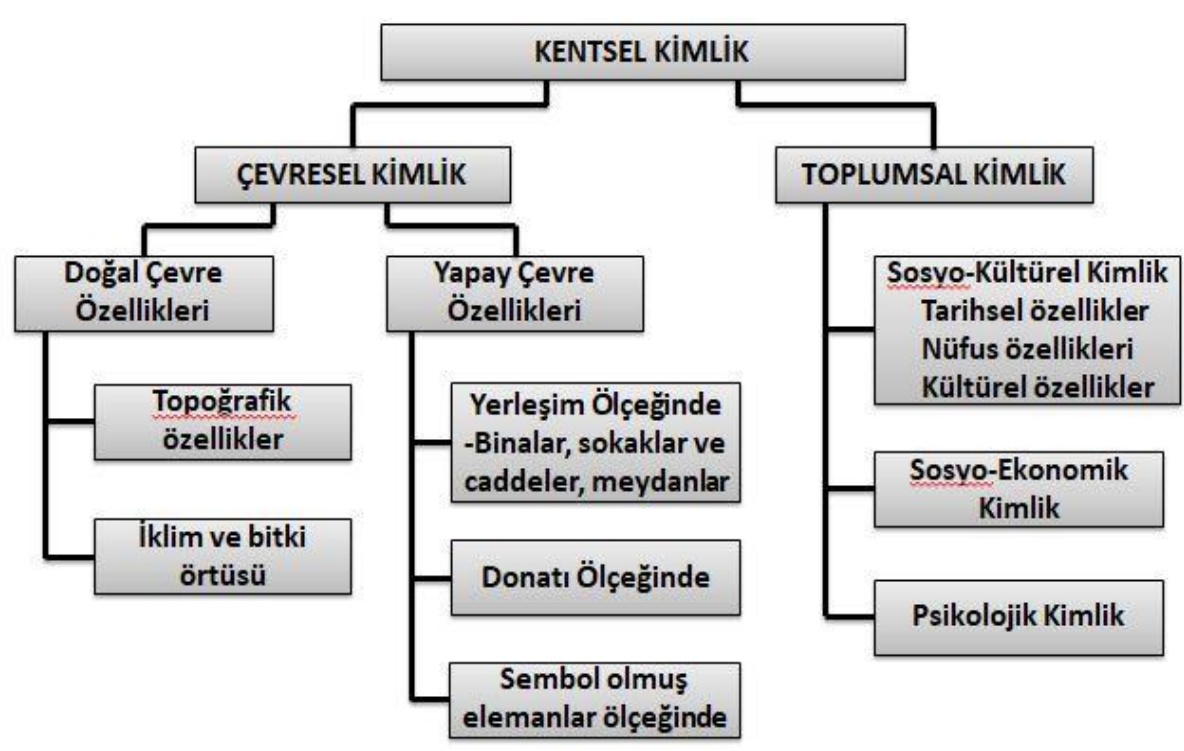

Şekil 1. Kent kimliğini oluşturan unsurlar.

Kaynak: (Topçu, 2011)

Kentte yaşayan bireyler, yaşadıkları kentle olan etkileşimlerinden dolayı kente özgü anlamlara ve anılara sahiptir (Alver, 2012). Kentte yaşayan bireylerin sahip olduğu bu unsurlar toplumun hafızasında yer edinerek kentin imgesi haline gelir (Rıza vd., 2012). Kentin sahip olduğu bir öğe, anıt niteliği taşıyan bir değer yani kent imgeleri kentlerin ayırt edici özelliklerini vurgulayarak kent kimliğinin oluşumuna katkı sağlar. Kentlerin imgelere sahip olmasının yanı sıra önemli olan kentlerin sahip olduğu bu imgelerin kentli hafizasında nasıl algılandığıdır. Kent kimliğinin belirleyicisi olan etmenlerden biride kentlinin hafizasında oluşan bu algıdır (Çöl, 1998; Erdoğan ve Çorbacıoğlu Akay, 2018). Kent kimliğinin oluşumunda kentsel mekan ve insan faktörlerinin ilişkisi önemli bir yerdedir. Mekanlara ancak mekanı devamlı olarak kullanan insanlar tarafından anlam yüklenebilir. Yani kent yalnızca fiziksel ve biçimsel unsurlardan değil bunun yanı sıra mekanı farklı kılan yaşanmışlıklardan da etkilenir (Perihan ve Aşur, 2020). İnsan, gereksinimleri doğrultusunda yeni mekanlar oluşturur, bunun sonucunda ihtiyaçlarını kente aktarır ve kent kimliğini ortaya çıkarır (Kaypak, 2010).

\subsection{Kent Kültürü}

Toplumu ve ortaya çıkmasındaki yerel bölümleri ayrıştıran birlikte planlanmış zeka şeklinde tanımlanan (Hofstede,1980; Negiz, 2017) kültür kavramı, somut ve somut olmayan değerler olarak sinıflandırılabilir. Somut kültürel değerler insanların gereksinimleri doğrultusunda oluşturdukları öğeler, somut olmayan kültürel değerler ise toplum kuralları, gelenek ve görenek gibi değerleri kapsar (Ataş, 2006; Negiz, 2017 ). Toplum geleceğinin doğru planlaması, toplumun geçmişini yansıtan ve bir bütün olma hissini sağlamlaştıran kültürel mirasla birlikte tecrübeler ve geçmişten gelen gelenek ve göreneklerin devamlılı̆̆ı ile sağlanır (ISMEP, 2014). Kültürel mirasın yitirilmesi sonucunda yerine yenisinin konulamayacak olmasından dolayı kültürel mirasın korunması, sürekliliğinin sağlanması çok önemlidir (Negiz, 2017). Günümüzde kentlerin kimliklerini yitirmeye başlamasıyla daha da önem taşıyan kültürel miras; somut kültürel miras, somut olmayan kültürel miras, sualtı kültürel mirası ve doğal miras olarak sinıflandırılmaktadır. [Şekil 2] Somut olmayan kültürel miras gelişimler sonucunda değişim gösterdiği için somut kültürel mirasa göre yitirilme olasıllğı daha yüksek değerlerdir (ISMEP, 2014). 


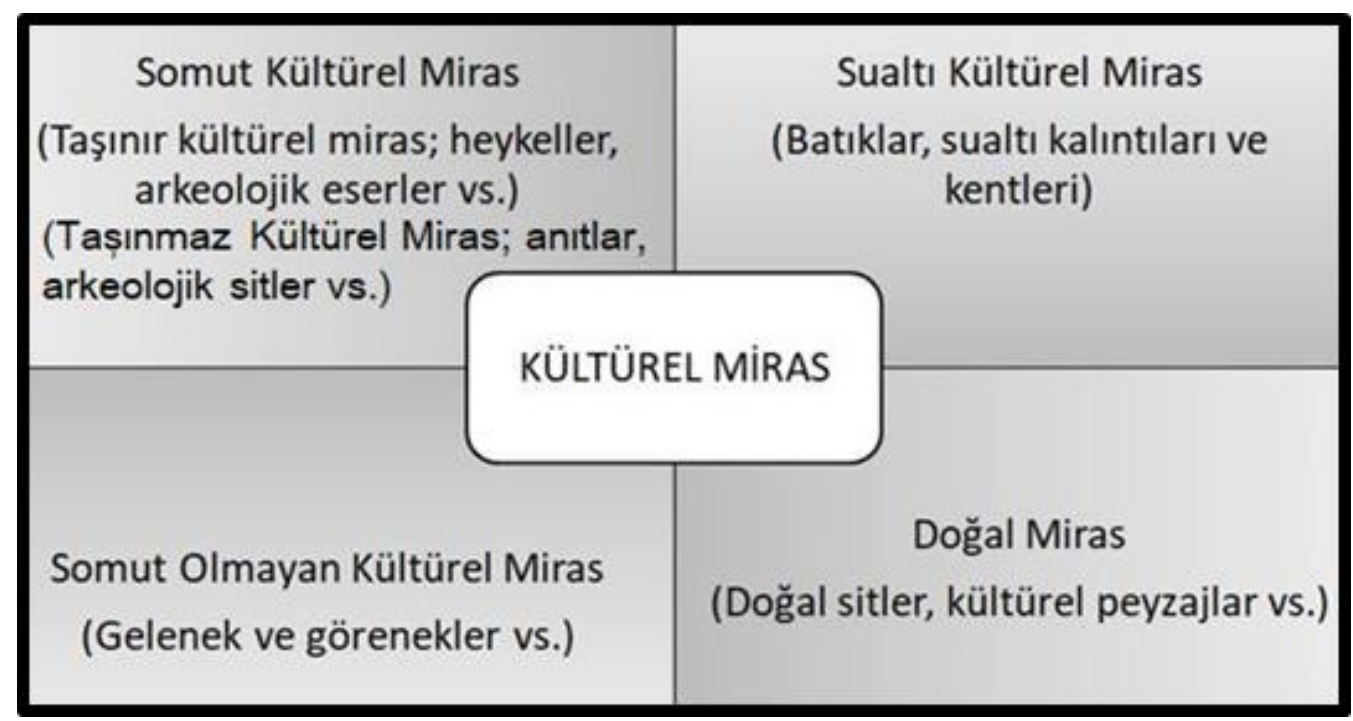

Şekil 2. Kültürel mirası oluşturan unsurlar.

Kaynak: (ISMEP, 2014).

Kent kültürü kentte yaşayan toplumun süreç içerisinde biriktirdiği somut ve soyut değerler olarak tanımlanabilir (Güler vd., 2016) ve kente kimlik kazandırmada önemli bir yerdedir. Geçmişten günümüze aktarılan kültür, toplumun kent kimliğini biçimlendirmedeki en önemli faktördür. $\mathrm{Bu}$ nedenle kentin kimliğinin oluşturulması ve geliştirilmesini sağlamak için kentin sahip olduğu kültürel değerlerin korunarak günümüze aktarılması ve sürekliliğinin sağlanması gerekmektedir. Bu noktada kent kimliğinin oluşturulması ve geleceğe taşınmasındaki önemli faktör olan toplumun yeri büyüktür (Tekeli, 1991; Koyuncu, 2013).

Kent kültürü kentte yaşayan toplumun yaşayış biçimi hakkında bilgi verir ve özgün kimliğini ortaya çıkarır (Es, 2007:91-92; Güler vd., 2016). Kentler sadece fiziksel bir mekan değil aynı zamanda insan ilişkilerini barındıran kültürel bir mekandır. Bu yönüyle kent kimliğinin oluşmasını sağlayan faktörlerin geniş çaplı olduğu görülmektedir (Güler vd., 2016). Kent kimliğini oluşturan coğrafi durum, tarihsel doku, toplumun kente olan aidiyeti, yaşam şekli ve gelenek görenekleri gibi etmenlere bakıldığında ve kent kültürünün geçmişten günümüze ulaşan somut ve soyut değerlerin bütünü olduğu düşünüldüğünde, kent kimliğini oluşturan faktörlerin, kent kültürünün temelini oluşturduğu anlaşılır ve kent kültürünün kent kimliğini oluşturan yapıtaşlarından olduğunu ortaya koyar (Alver, 2009:430; Güler vd., 2016; Öztürk vd., 2020b).

\section{MATERYAL VE METOT}

Çalışma kapsamında Samsun-Kale Mahallesi bölgesi incelenmiş olup sahip olduğu değerler tespit edilerek ortaya çıkarılmıştır. 2.1 ve 2.2 bölümlerinde alana ilişkin tanımlamalar ve yöntem ile ilgili bilgiler verilmiştir.

\subsection{Materyal}

Çalışmanın ana materyalini, Samsun kenti Kale Mahallesi oluşturmaktadır. Kale Mahallesi, Karadeniz Bölgesinde yer alan Samsun İlinin İlkadım ilçesinde bulunmaktadır. [Şekil 3]. Kale Mahallesini sınırlarını; kuzeyde tütün iskelesi, doğuda onur anıtı, batıda ise Saathane Meydanı oluşturmaktadır. 


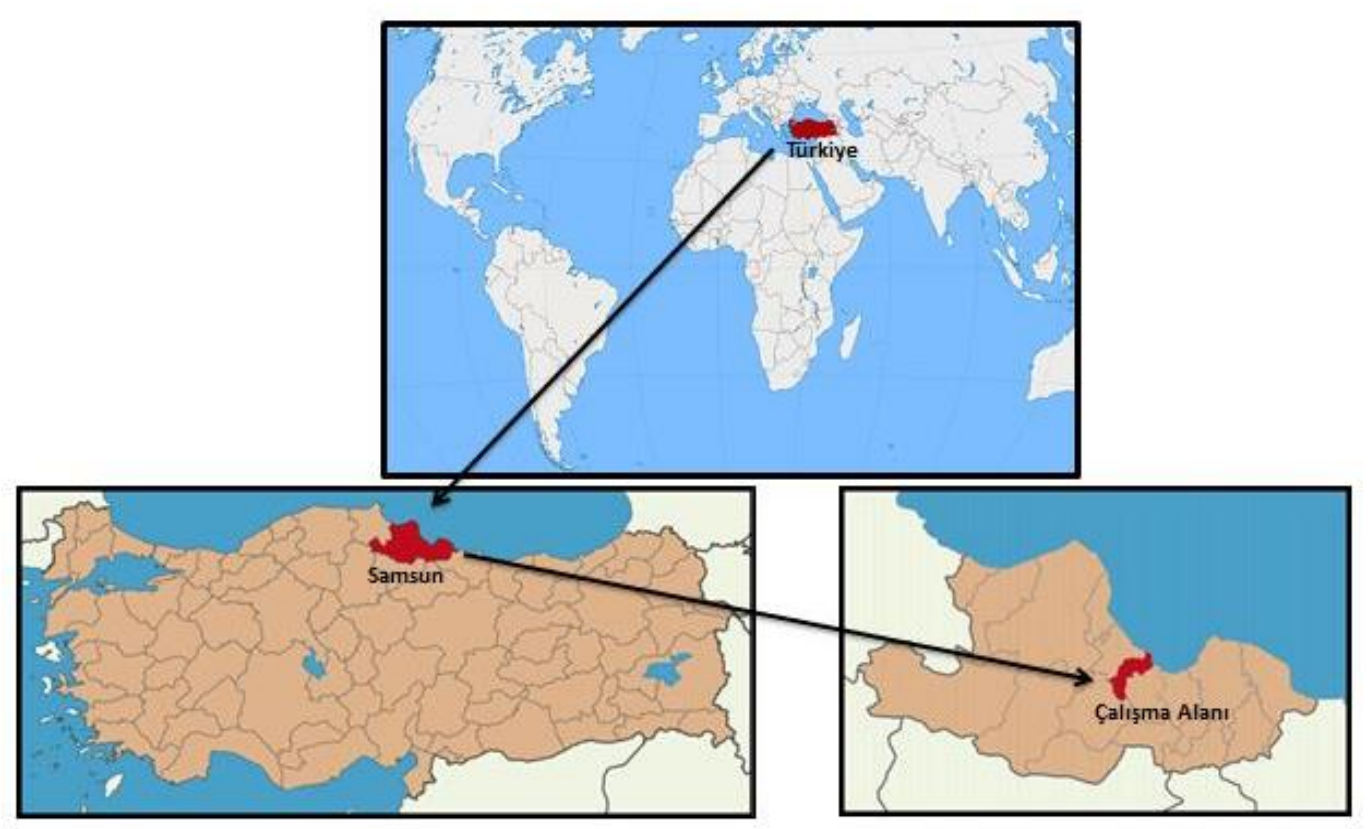

Şekil 3. Çalışma alanının dünyada ülke ve Samsun İlindeki Konumu.
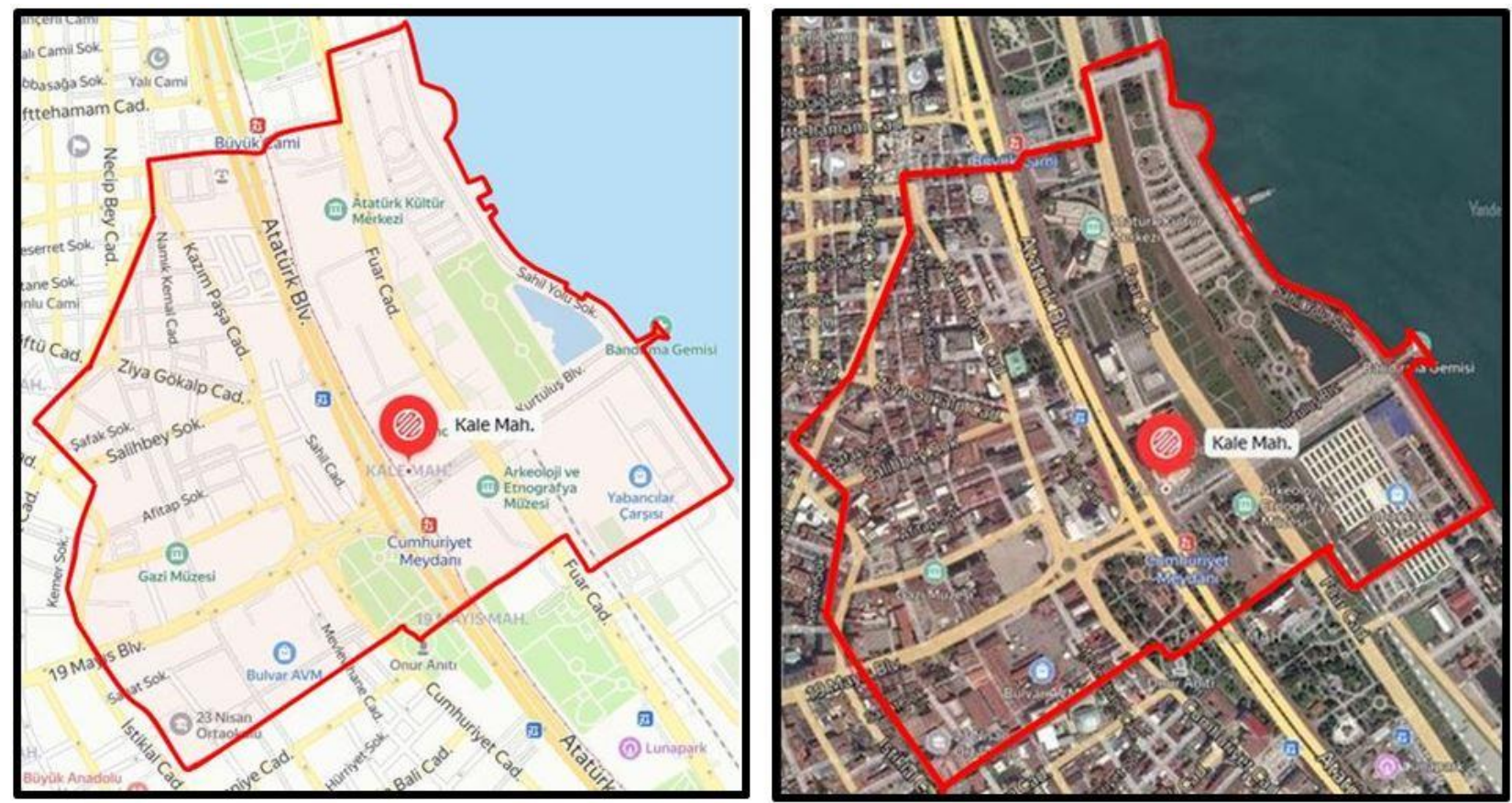

Şekil 4. Kale Mahallesinin sınırları.

Çalışma kapsamında incelenen ve Samsun'un İlkadım İlçesi'nin 61 mahallesinden biri olan, Kale Mahallesi şehrin tarihi merkezini oluşturan en eski mahallerinden biridir [Şekil 4]. Aynı zamanda önemli bir tarihsel geçmişe sahip olan Samsun İlinin barındırdığı çok sayıdaki değer çalışma kapsamında belirlenen bu alan içerisinde bulunmaktadır.

Çalışma alanı olarak Samsun İlinde bulunan Kale Mahallesinin belirlenmiş olmasının nedenleri; alanın büyük bir kısmının kentsel sit alanı olarak korunuyor olması, zengin tarihi özellikleri olan alanın kentsel imge niteliğindeki çok sayıda değer barındırması ve bu değerlerin birçoğunu günümüze taşıyabilmiş olmasıdır. 


\subsection{Metot}

Çalışmanın metodu iki başlık altında toplanmıştır. Birincisi alana ilişkin literatür ve arşiv araştırmalarının yapılmasıdır. İkincisi ise alana yönelik yerinde gözlem ve analizlerin yapılmasıdır.

Birinci aşamada konuyla ilgili yapılmış olan makaleler, bildiriler ve yapılmış lisansüstü tezlerden faydalanılmıştır. İkinci aşamada alana yönelik yerinde gözlem ile kent kimliğine etki edecek kültürel değerler fotoğraflanmıştır. Bu esnada alanda yaşayan halk ve esnaflarla yerinde görüşme yapılmıştır.

\section{3. ÇALIŞMA ALANI}

\subsection{Samsun Kenti Tarihi ve Kültürel Gelișimi}

Karadeniz'e ulaşımda önemli bir noktada yer alan Samsun kenti, büyük bir tarihi geçmişi barındırmaktadır [Resim 12]. İlk yerleşim tarihi MÖ 3500'lü yıllara kadar uzanan kentin yerleşimine ait kalıntılar alan içerisinde bulunan höyüklerden elde edilmiştir (Uzuneminoğlu, 1993). Yapılan kazılarda, kentin Kalkolitik, Eski Tunç ve Hitit olmak üzere üç farklı kültür katmanına sahip olduğu belirlenmiştir (Kökten, 1945). Samsun kenti dönemsel süreç içerisinde Hitit, Pers, Roma, Bizans, Selçuklu ve Osmanlı gibi çok sayıda uygarlığı ağırlamıştır (Tüfekçioğlu ve Boran, 2004).
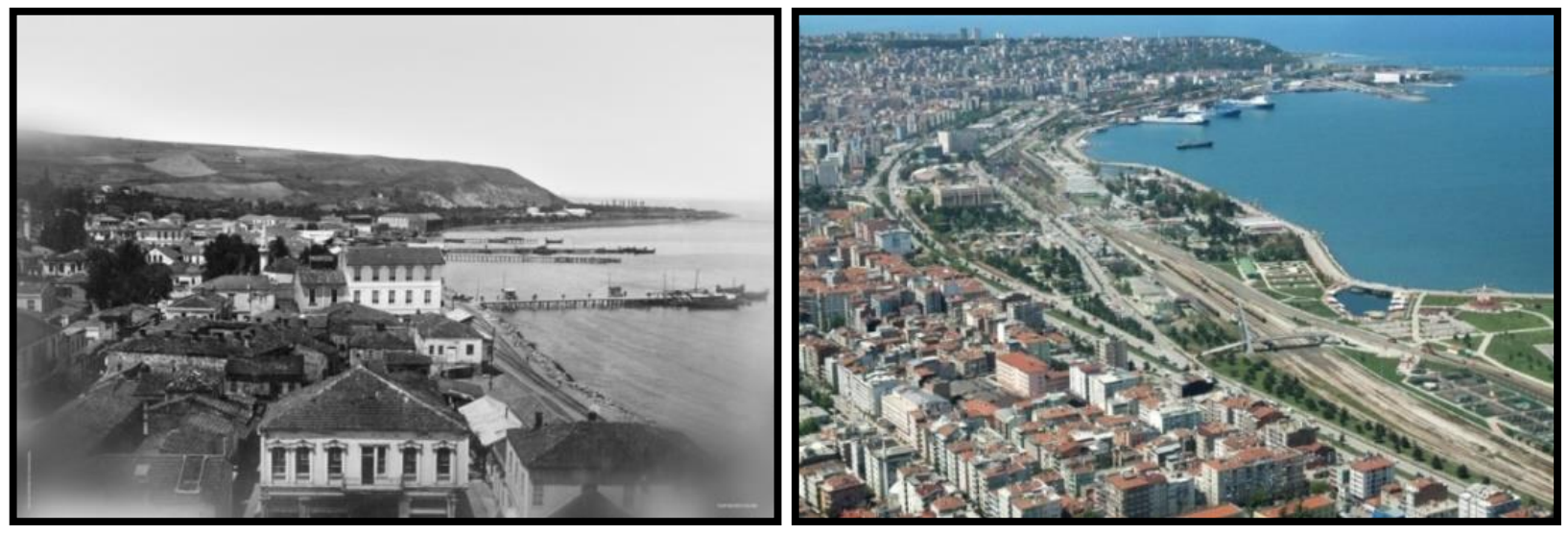

Resim 1-2. Tarihsel Süreç İçerisinde Samsun Kenti Değişimi.

(Kaynak: Samsun İl Kültür ve Turizm Müdürlüğü Arşivi -URL1.)

Samsun kenti dönem dönem gerileme yaşamış olsa da 19. yüzyılda tekrar gelişmeye başlamıştır. Kentin gelişimini önemli bir liman kenti oluşu, tütün üretiminin yoğunluğu ve çok sayıda göç alımı gibi faktörler daha da hızlandırmıştır (Erler, 2007; Yılmaz ve Gül, 2018). Ticaretin gelişimiyle birlikte de kentte birçok Rum ve Ermeni tüccar bulunmuştur (Yolalıcı, 1998; Yılmaz ve Gül, 2018). Bu tarihsel olaylar kentteki yapıların mimari özelliklerine de yansımıştır. 1869 yılında kentte meydana gelen büyük yangın sonucunda kentin sahip olduğu çok sayıda yapı kaybedilmiştir ve şehir yeniden planlanmıştır. Aynı zamanda 1950 yılı sonrasında yaşanan hızlı nüfus artışı hızlı bir yapılaşmayı da beraberinde getirmiştir (Sarısakal, 2002). 

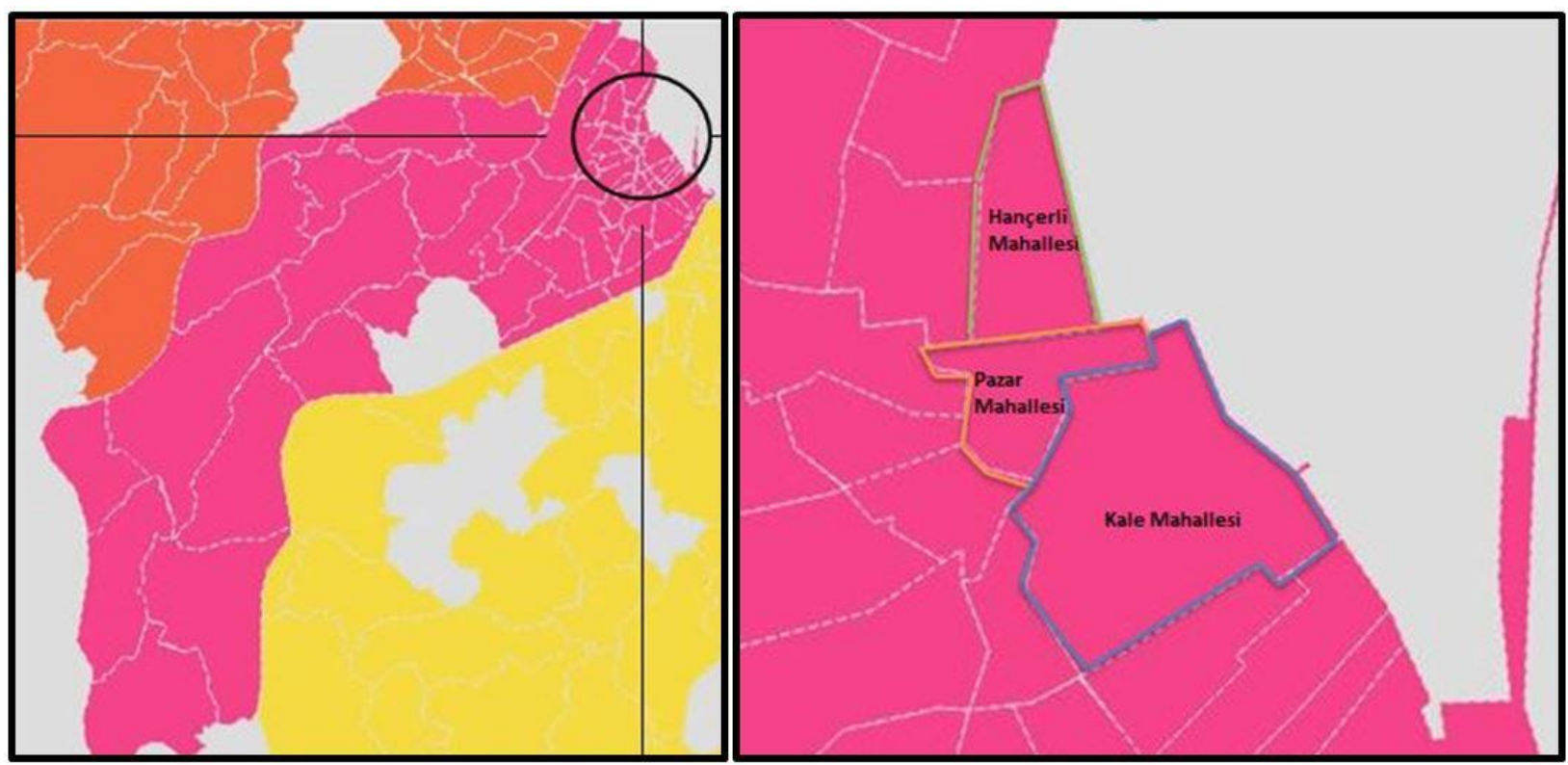

Şekil 5. Samsun kenti Pazar-Hançerli ve Kale Mahalleri İlk Kuruluş Bölgesi. (Kaynak: URL2.)

Selçuklular tarafından ilk yerleşme olan Amisos'un doğusunda kurulan Samsun'un ilk kuruluş yeri Pazar, Kale ve Hançerli Mahallelerinin bulunduğu alanı kapsamaktadır [Şekil 5]. Kent yaşanan çok sayıdaki göç ile tarihsel süreç içerisinde çeşitli kültür ve milletten insan barındırmış (Yolalıcı, 1998; Yılmaz ve Gül, 2018) ve bu kentin mimari özelliklerine de yansımıştır. Kentte gelişen ticaretin etkisiyle çok sayıda konsolosluk açılmış ve bunlar kentin sahip olduğu önemli yapılardan olmuştur. Aynı zamanda kentte banka yapıları da önemli mimari miraslardandır. Batı üslubu taşıyan bu yapılar Kale Mahallesi içerisinde bulunan Kazımpaşa (Bankalar) caddesinde bulunmaktadır [Resim 3-4]. Önemli bir ticaret merkezi olmasından dolayı kentte hanlar, işyerleri ve bedestenler [Resim 7-8] ve Türk kültürünü yansıtan hamamlarda mevcuttur (Sarısakal, 2002). Samsun kent kimliğini etkiyen faktörlerin en önemlisi Mustafa Kemal Atatürk'ün milli mücadelede başlangıç yeri olarak Samsun'u belirlemesidir. 19 Mayıs 1919'da Mustafa Kemal Atatürk'ün kurtuluş mücadelesini başlatmak üzere Samsun'a ayak bastığı iskele, Kurtuluş Yolu [Resim 5-6], kente geldiği Bandırma Vapuru kent kimliğinin biçimlenmesinde rol oynayan kentin imgesi haline gelmiş öğelerdendir. Günümüzde Karadeniz'in en büyük kentlerinden olan Samsun, gerek konumu gerek barındırdığı tarihi özellikleri ile ülkemizin önemli kentlerinden biri olmuştur.
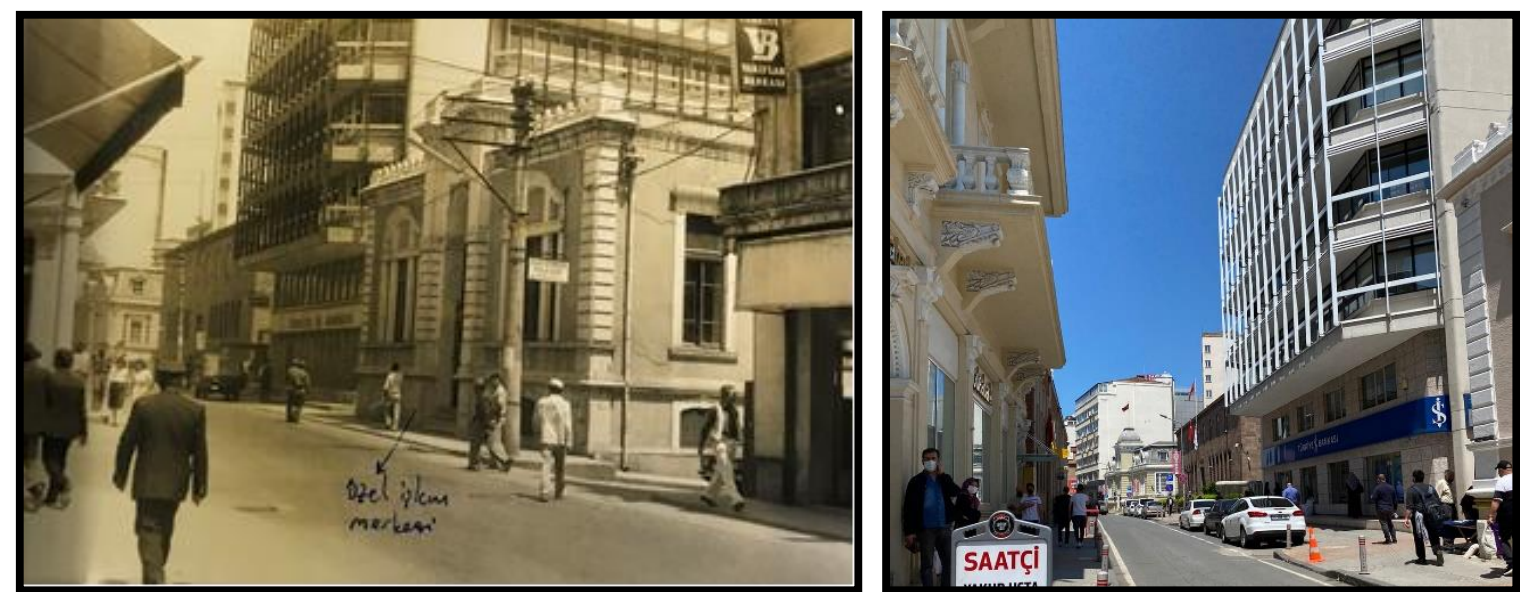

Resim 3-4. Bankalar Caddesi (1996) - Bankalar Caddesi (2021).

(Kaynak: Samsun Kültür ve tabiat varlıklarını koruma kurulu arşivi - Birnur KÖSE, 2021) 

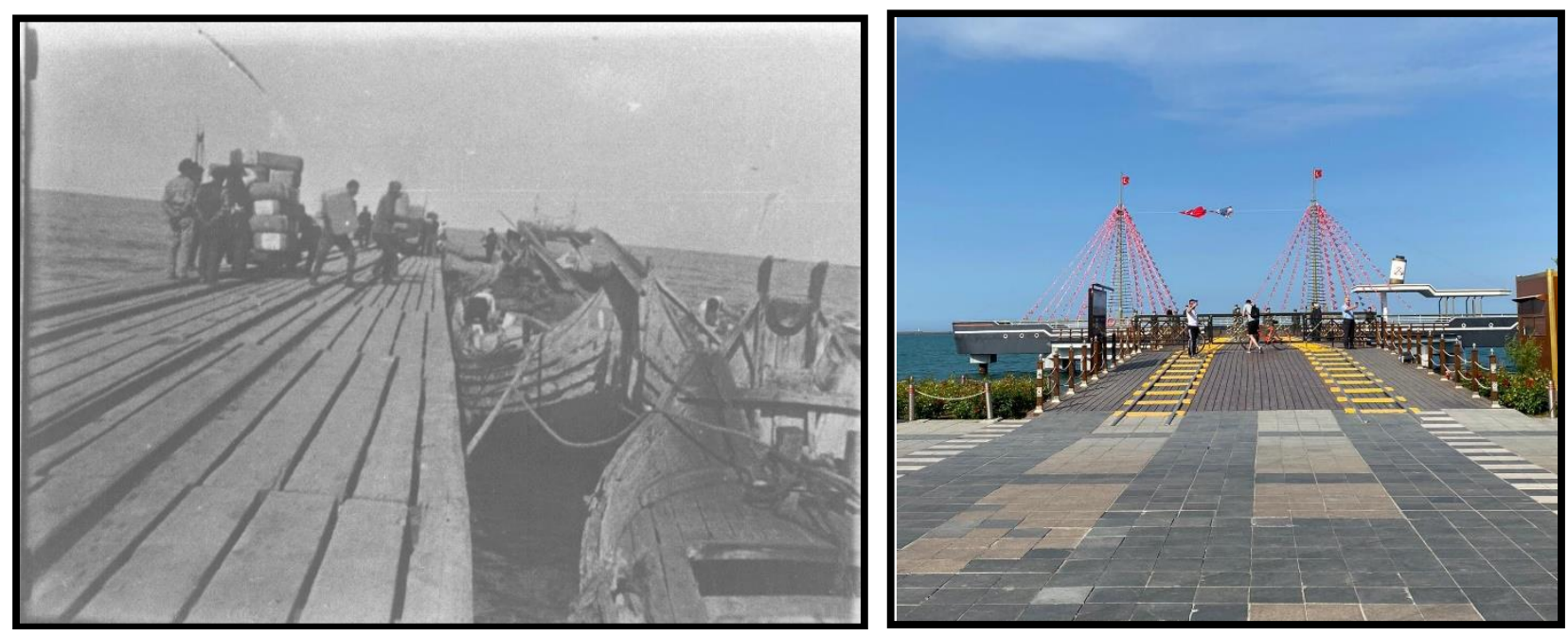

Resim 5-6. Samsun Kurtuluş Yolu.

(Kaynak: Samsun Kültür ve tabiat varlıklarını koruma kurulu arşivi - Birnur KÖSE 2021)
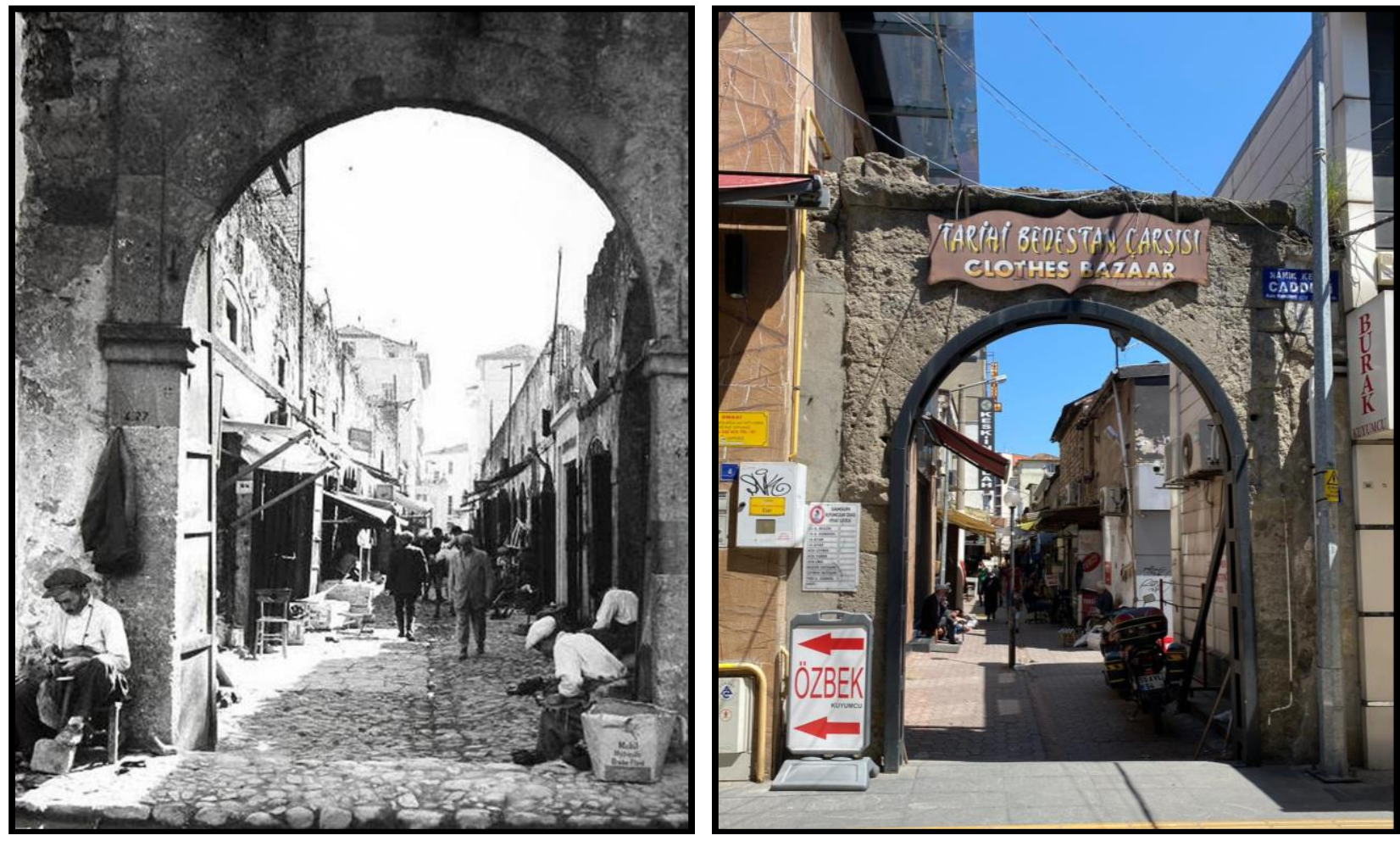

Resim 7-8. Samsun Tarihi Bedesten.

(Kaynak: https://www.meydannet.com/haber/samsunun-en-eski-carsisi-81820.html - Birnur KÖSE 2021) 
Çalışma alanı olarak belirlenen kentin en eski mahallelerinden olan Kale Mahallesi, kentin en kalabalık olduğu ve çok sayıda iş yeri barındıran bir mahalledir. Mahalle adını Samsun Kalesinden almaktadır [Resim 9-10]. Geçmiş tarihlerde Mekte Mahallesi ve Cami Kebir mahallesi adıyla da adlandırılmıştır (Sarısakal, 2002). Samsun kentinin ilk kuruluş yerlerinden biri olan Kale Mahallesi içerisinde barındırdığı değerlerle Samsun kent kimliği açısından ön plandadır. Hem ticari fonksiyonu hem de kentsel hafızanın bir parçası olması açısından Samsun kenti için önemli olan tarihi dokuya sahip, Kale Mahallesinin büyük bir kısmı kentsel sit alanı olarak korunmaktadır [Şekil 6-7-8].
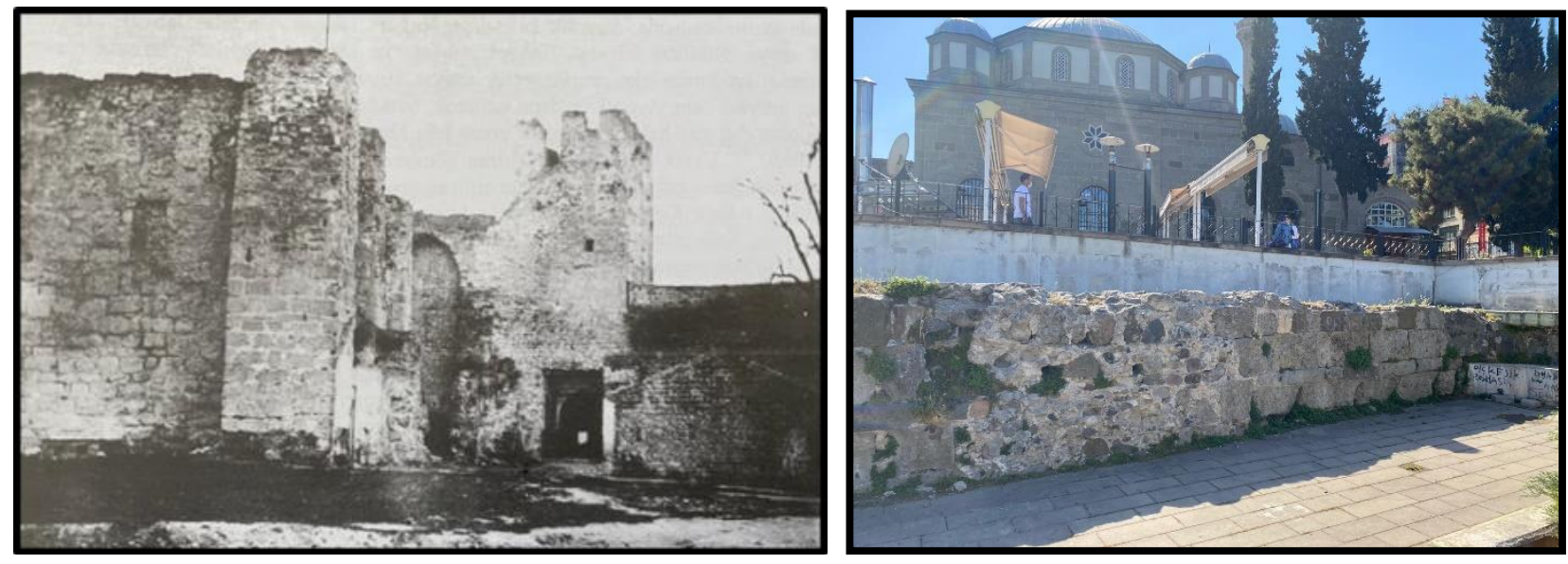

Resim 9-10. Samsun Kalesi - Samsun Kalesi Kalıntıları (2021).

(Kaynak: İstanbul Üniversitesi Arşivi; Sarısakal, 2002 - Birnur KÖSE 2021)

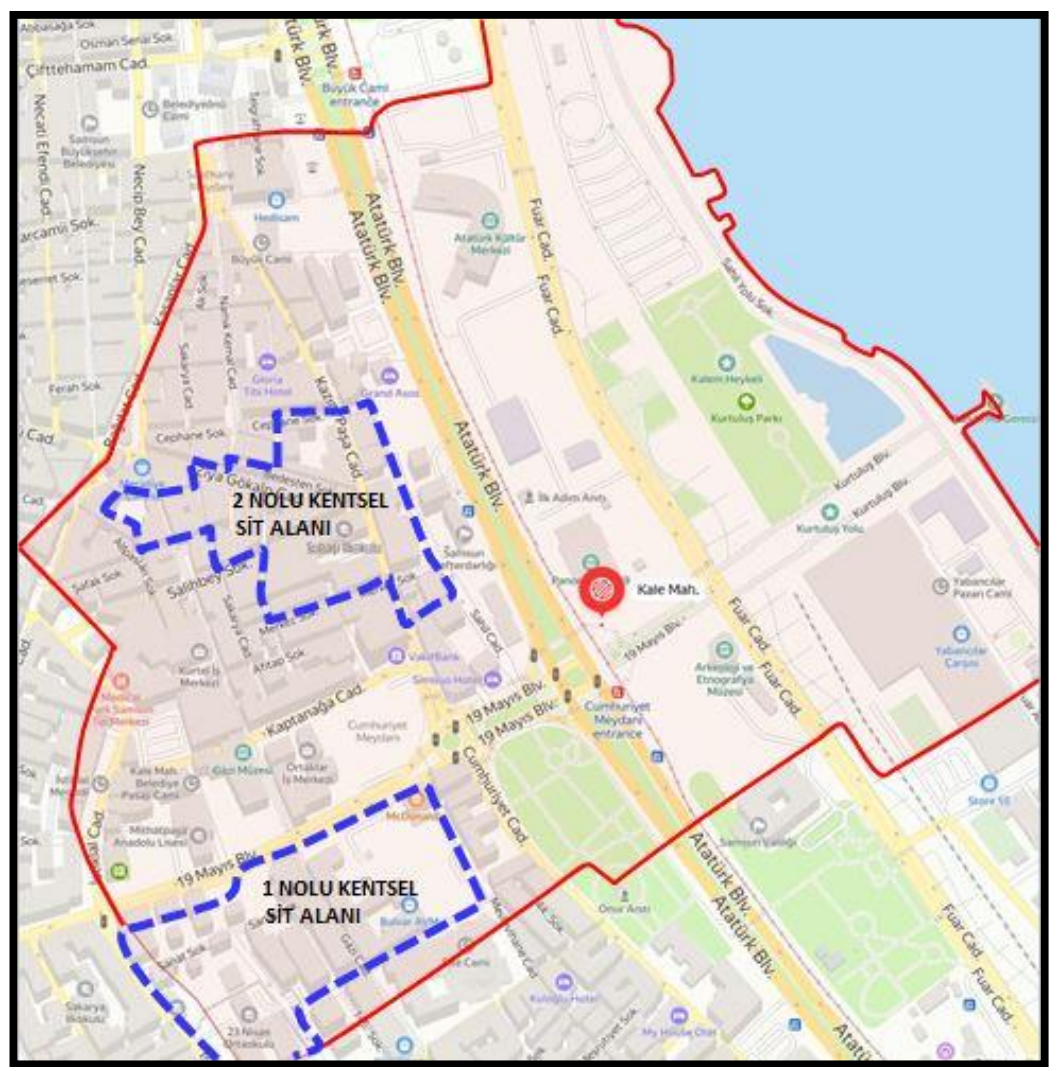

Şekil 6. Kale Mahallesi Kentsel Sit Alanları. 


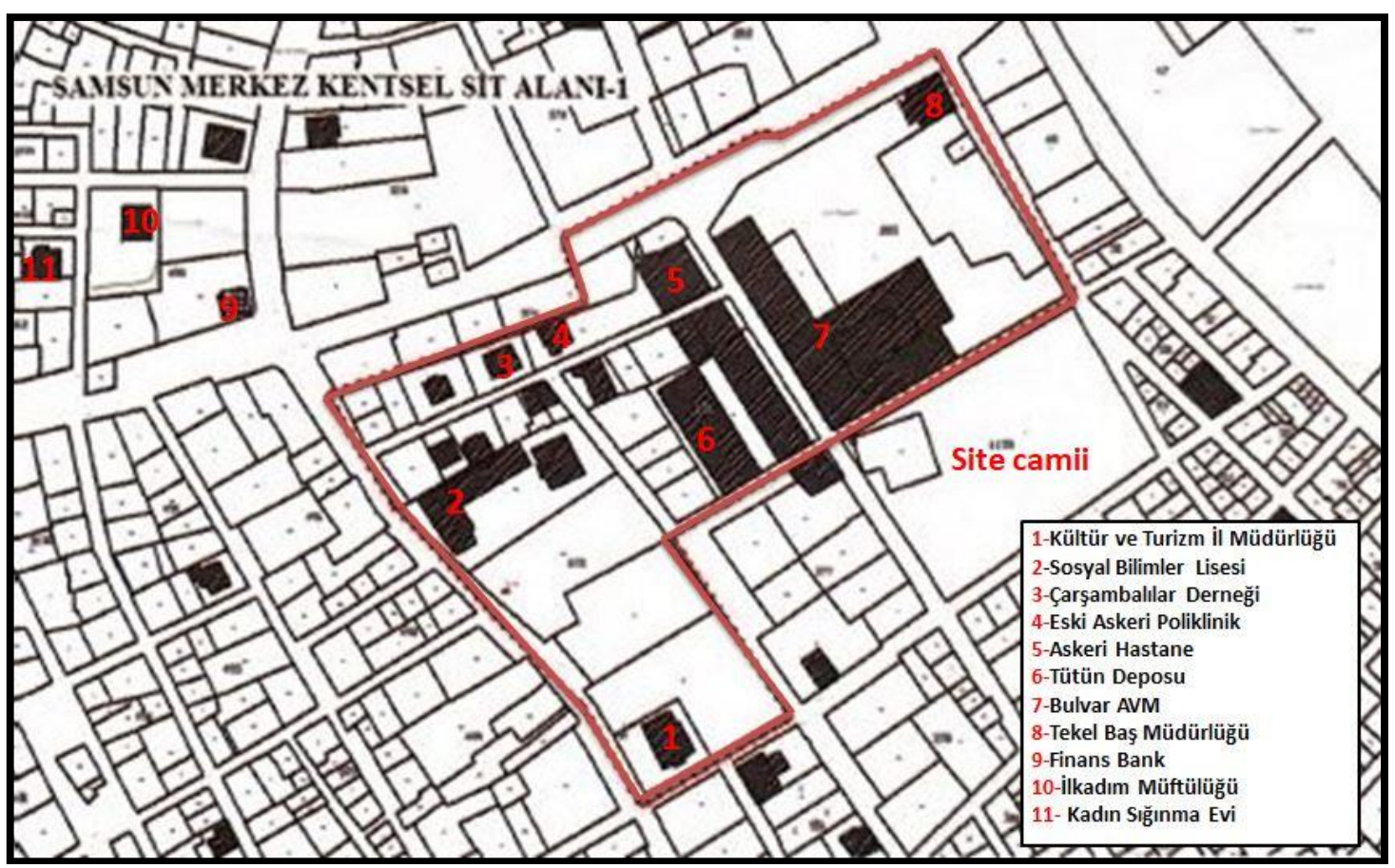

Şekil 7. Kale Mahallesi Sınırları İçerisinde Yer Alan 1 Nolu Kentsel Sit Alanı.

(Kaynak: Samsun Valiliği İl Özel İdaresi Taşınmaz Kültür Varlıkları Envanteri, s. 71.)

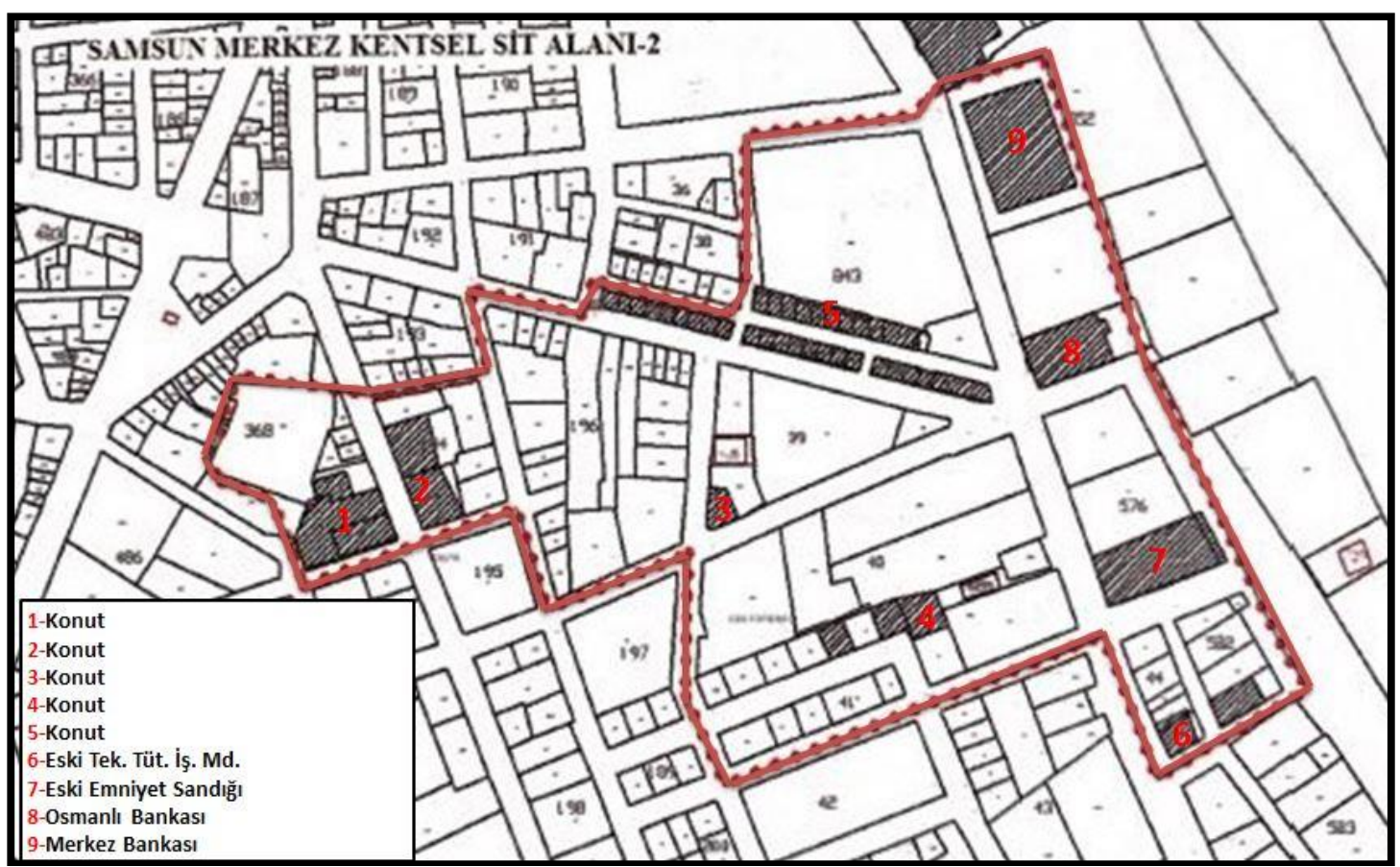

Şekil 8. Kale Mahallesi Sınırları İçerisinde Yer Alan 2 Nolu Kentsel Sit Alanı.

(Kaynak: Samsun Valiliği İl Özel İdaresi Taşınmaz Kültür Varlıkları Envanteri, s. 71.)

Samsun-Kale Mahallesi bölgesinde kentsel kimlik bileşenleri açısından yapılan alan çalışmaları ve görsel analizler ışığında değerlendirmeler yapılmıştır. 


\section{ARASTTIRMA BULGULARI}

\subsection{Doğal Çevre Bileşenleri Bakımından Samsun-Kale Mahallesi}

Kentin kendiliğinden sahip olduğu doğal özellikler olan, doğal çevre bileşenleri; iklim, bitki örtüsü ve coğrafi açıdan incelenmiştir. Kale Mahallesi bölgesinin doğal çevre özellikleri irdelendiğinde ilk kuruluş yeri olmasından dolayı mahallenin bazı bölümleri geçmişte Samsun kalesi surları içerisinde yer almıştır. Ancak tarihsel süreç içerisinde kale surları yok olmuş ve sadece bazı bölgelerde kalıntıları kalmışıtır [Resim 11]. Alan incelendiğinde güney yönünde bir eğim ve buna bağlı olarak yokuş sokaklar ve caddeler görülmektedir [Resim 12-13].

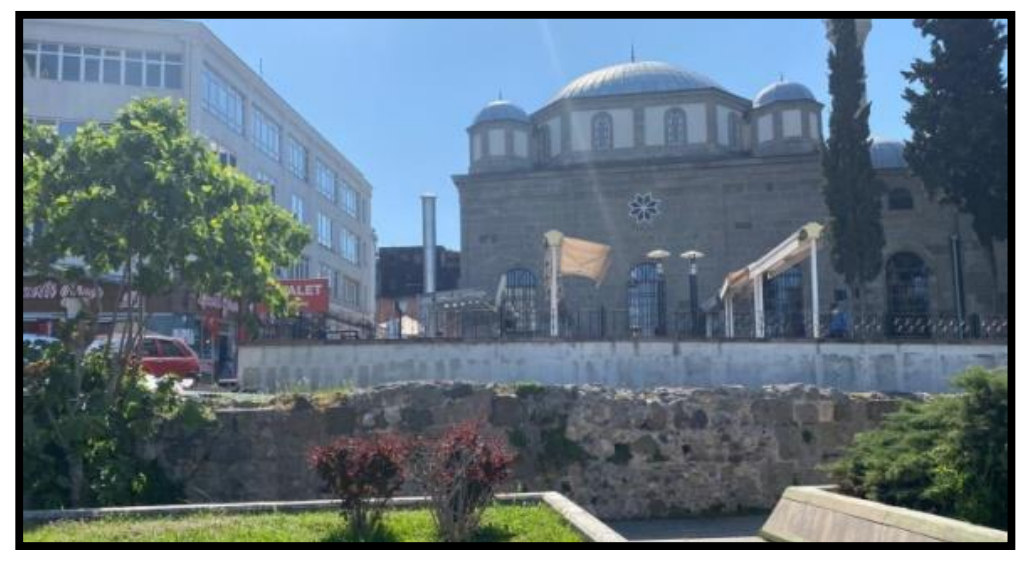

Resim 11. Samsun Kalesi Tarihi Sur Kalıntıları (Kaynak: Birnur KÖSE, 2021.)
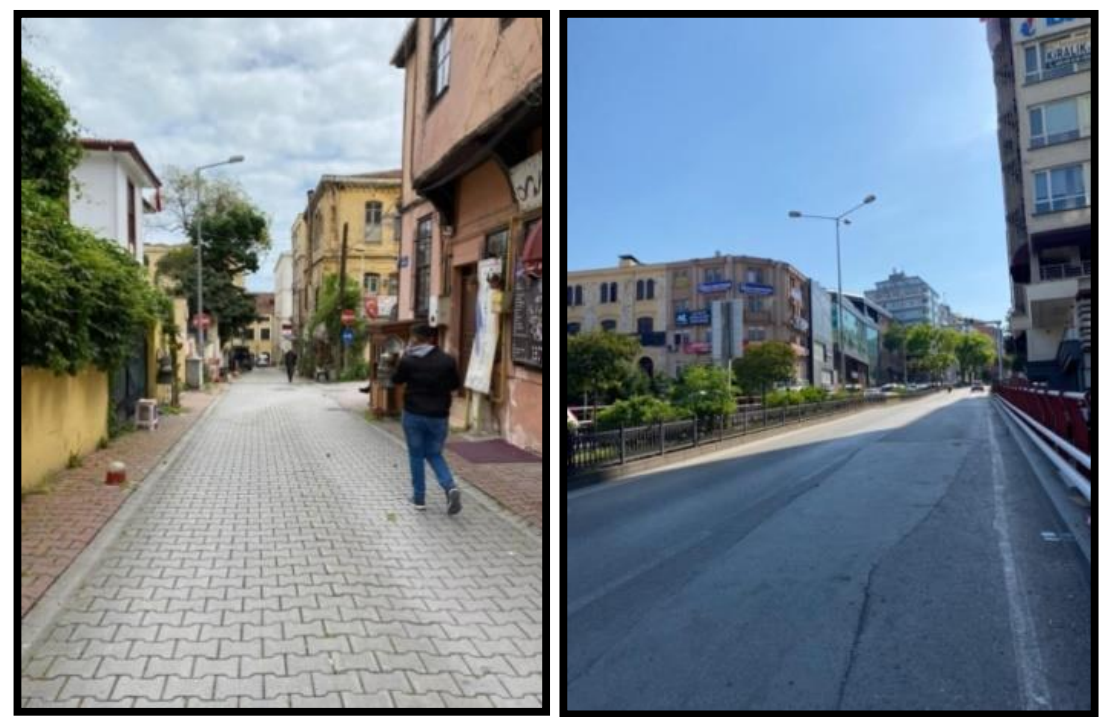

Resim 12-13. Samsun Kale Mahallesi Sanat Sokağı - 19 Mayıs Bulvarı (Kaynak: Birnur KÖSE, 2021.)

Alanda Karadeniz iklim özellikleri görülür; yazlar sıcak, kışlar ılık ve yağışlı geçer. Alanın sahip olduğu doğal çevre özelliklerini yitirdiği ve aynı zamanda tarihte Atatürk Parkı ve Saathane Meydanındaki Büyük camiye kadar ulaşan su varlığını süreç içerisindeki değişimler sonucunda günümüze taşıyamadığı görülmektedir [Resim 14-15-16-17-18]. Alan içerisinde yer alan Atatürk Parkı, Kurtuluş Parkı, Cumhuriyet meydanı ve Saathane meydanı gibi mekanların çevresinde özellikle taşıt yolu kenarlarında yeşil alan görmek mümkündür [Resim 19-20-21-22-23-24]. Samsun kent kimliği açısından önemli ve tarihi dokuya sahip olan Saathane Meydanında Kale Mahallesindeki koruma altına alınan, uzun bir tarihi geçmişe sahip çınar ağacı bulunmaktadır [Resim 25-26]. 

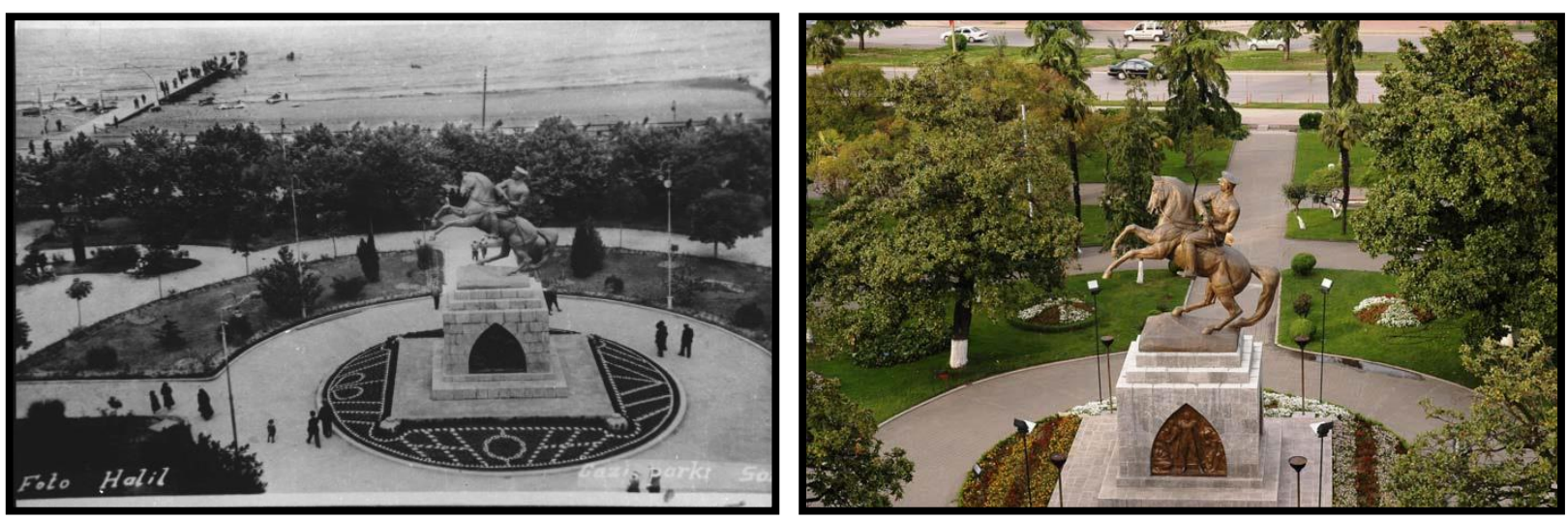

Resim 14-15. Samsun Kale Mahallesi Atatürk Park1.

(Kaynak: : Samsun İl Kültür ve Turizm Müdürlüğü Fotoğraf Arşivi)
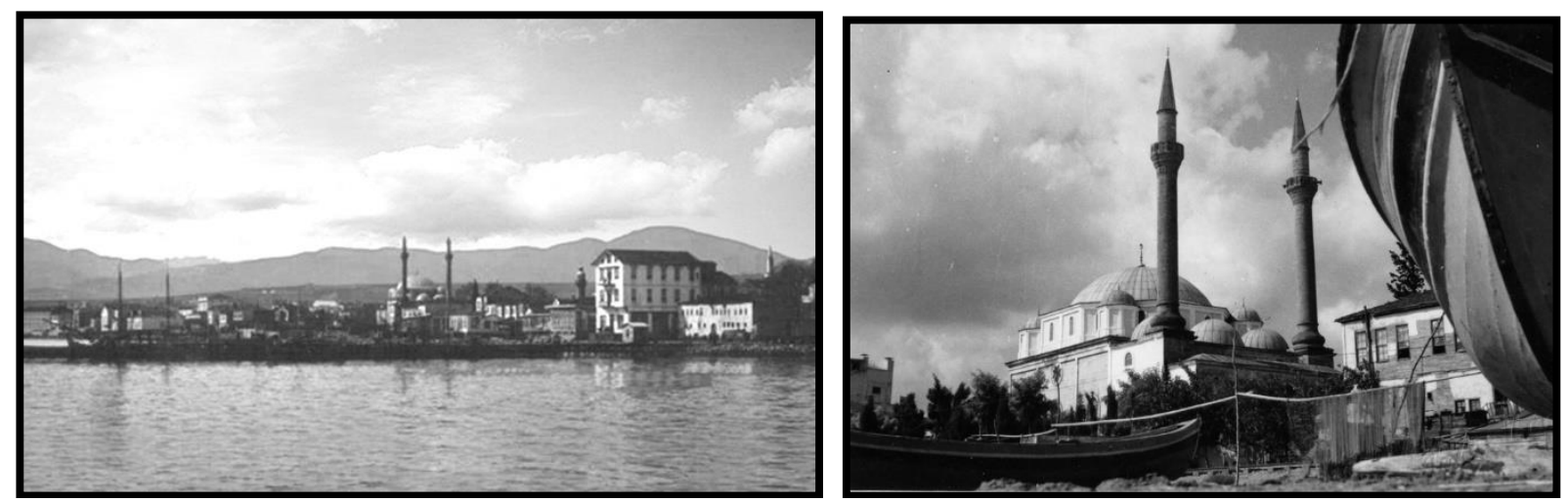

Resim 16-17. Samsun Kale Mahallesi Atatürk Park1.

(Kaynak: : Samsun İl Kültür ve Turizm Müdürlüğü Fotoğraf Arşivi)

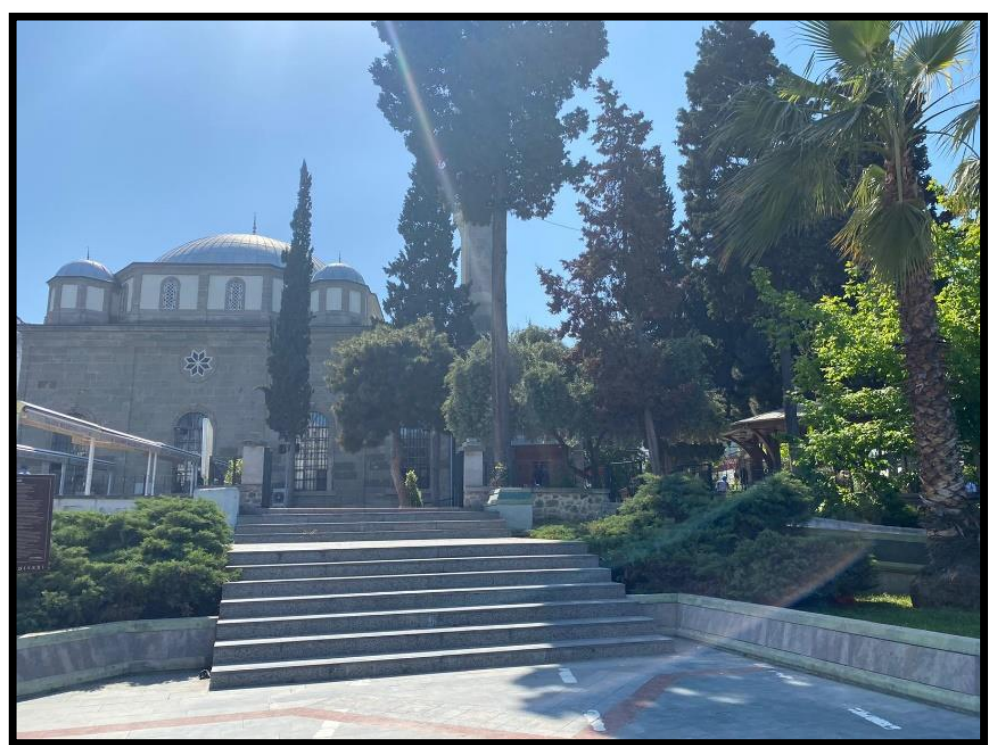

Resim 18. Samsun Kale Mahallesi Atatürk Park1. 

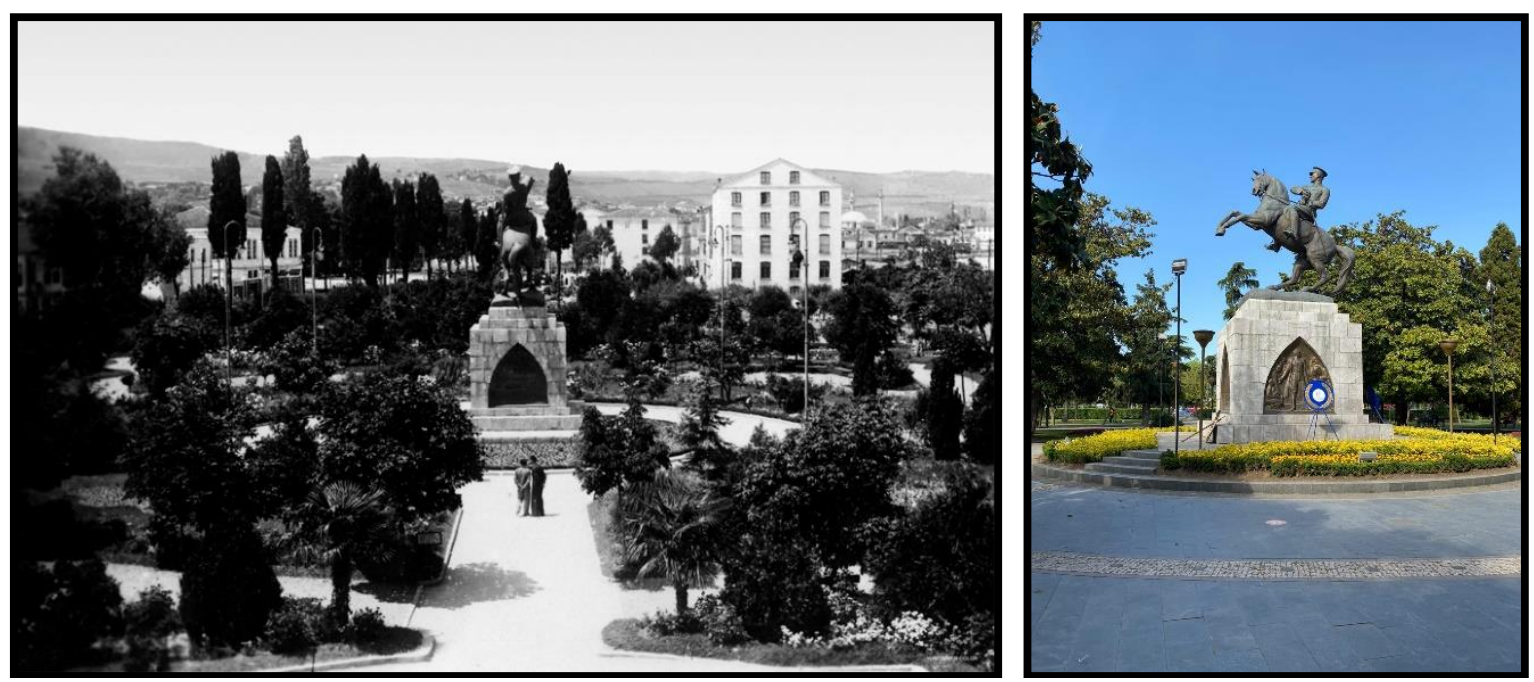

Resim 19-20. Samsun Kale Mahallesi Atatürk Park1.

(Kaynak: : Samsun İl Kültür ve Turizm Müdürlüğü Fotoğraf Arşivi - Birnur KÖSE, 2021.)
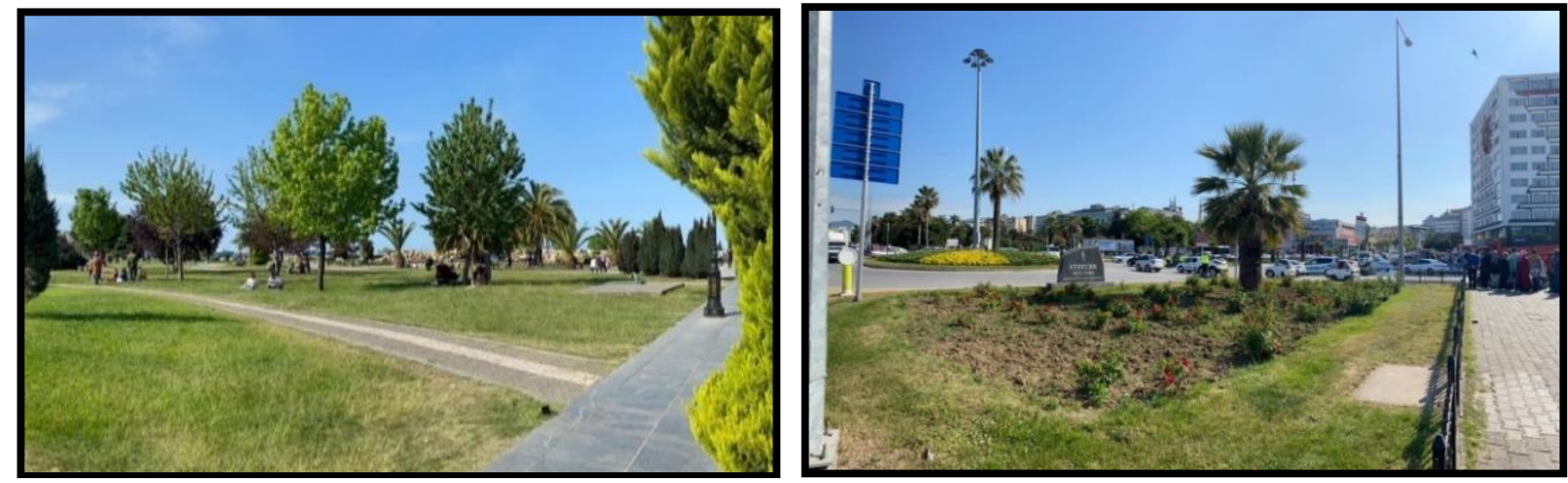

Resim 21-22. Samsun Kale Mahallesi Kurtuluş Parkı - Cumhuriyet Meydanı Çevresi(Kaynak: Birnur KÖSE, 2021.)
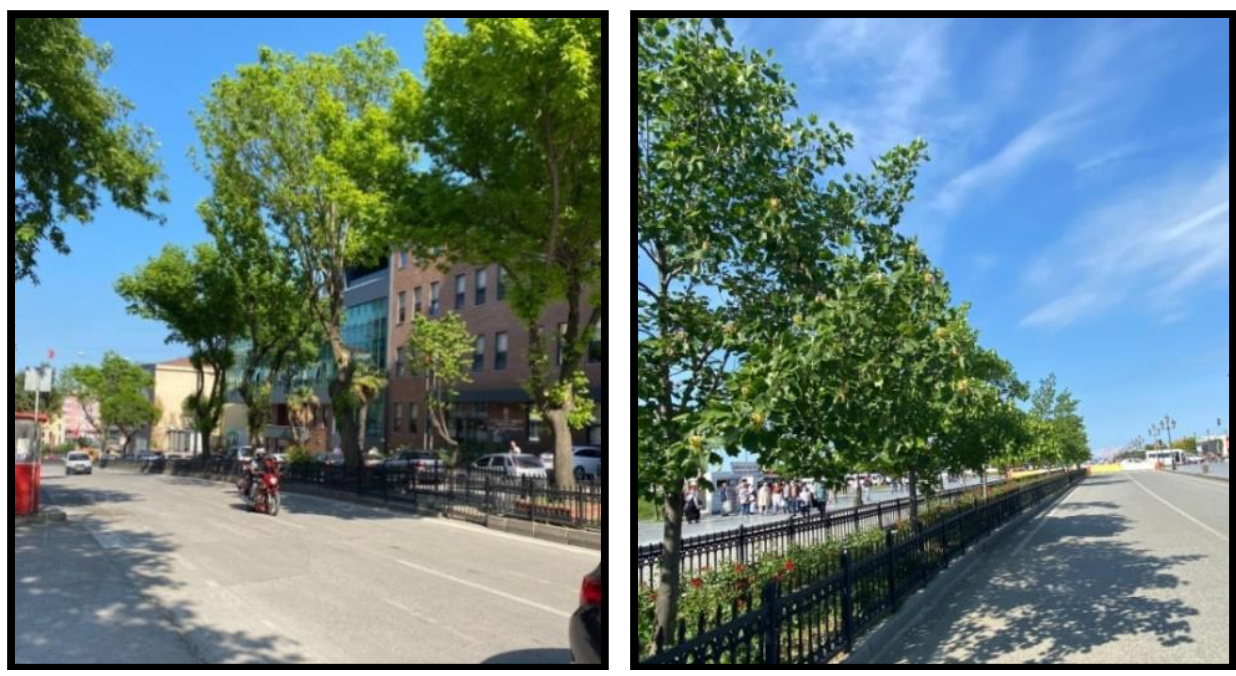

Resim 23-24. Samsun Kale Mahallesi 19 Mayıs Bulvarı (Kaynak: Birnur KÖSE, 2021.) 

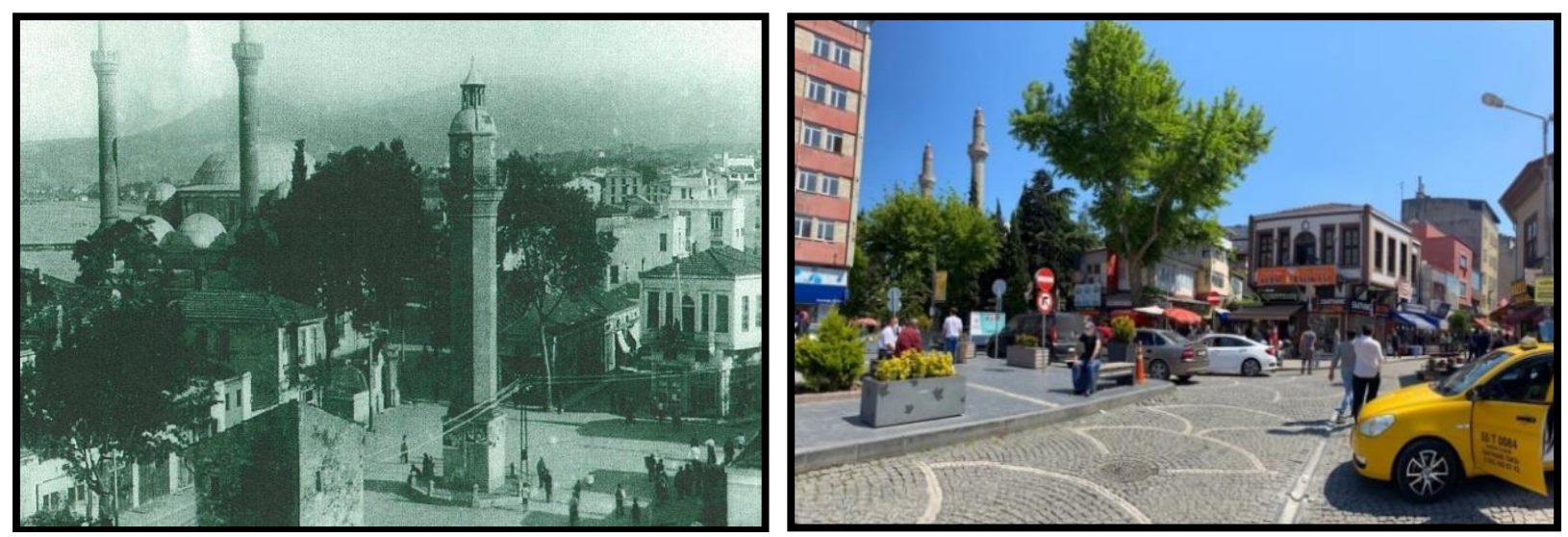

Resim 25-26. Samsun Kale Mahallesi Saathane Meydanı Tarihi Çınar Ağacı.

(Kaynak: Samsun İl Kültür ve Turizm Müdürlüğü Fotoğraf Arşivi - Birnur KÖSE, 2021.)

Kale Mahallesi bölgesindeki Bulvar AVM, Atatürk Parkı ve Kurtuluş Parkı gibi alanlarda rekreasyon ve çocuk oyun alanları bulunuyor olsa da Mecidiye çarşısı gibi bazı alanlarda ise gerekli rekreasyon alanı bulunmamaktadır [Resim 27-28]. Aynı zamanda çarşı bireyler için gölgelemeyi de sağlayacak olan ağaç ya da buna yardımcı elemanlar içermemektedir. Çalışma alanı içerisindeki Bedesten çarşısı gibi bazı mekanlar da gölgelendirme dükkan önündeki tenteler ve yer yer mevcut olan örtüler ile sağlanmaktadır [Resim 30-31]. Bu eksiklikler doğal çevrenin korunamadığ1 ve yapay çevre öğelerinin doğal öğelerle bütünleşemediği, yapılan tasarımların doğru planlanmadığını göstermektedir. Yapılan yoğun sert zemin tasarımı ve doğal alan eksikliği ile yapay bir çevre görünümü oluşturan Cumhuriyet Meydanında da bu tasarım yetersizliği görülmektedir [Resim 29].
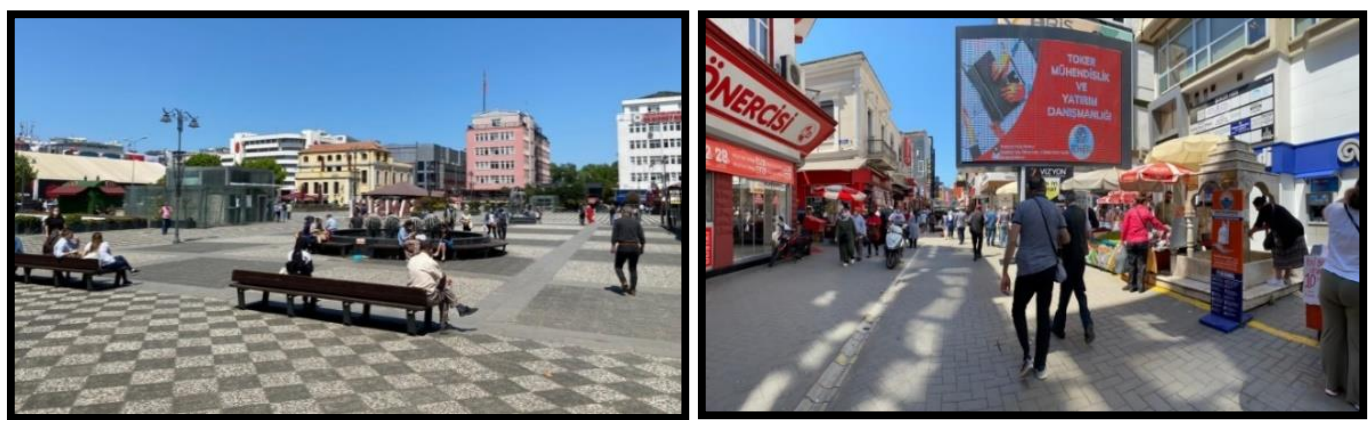

Resim 27-28. Samsun Kale Mahallesi Bulvar AVM - Mecidiye Çarşısı (Kaynak: Birnur KÖSE, 2021.)

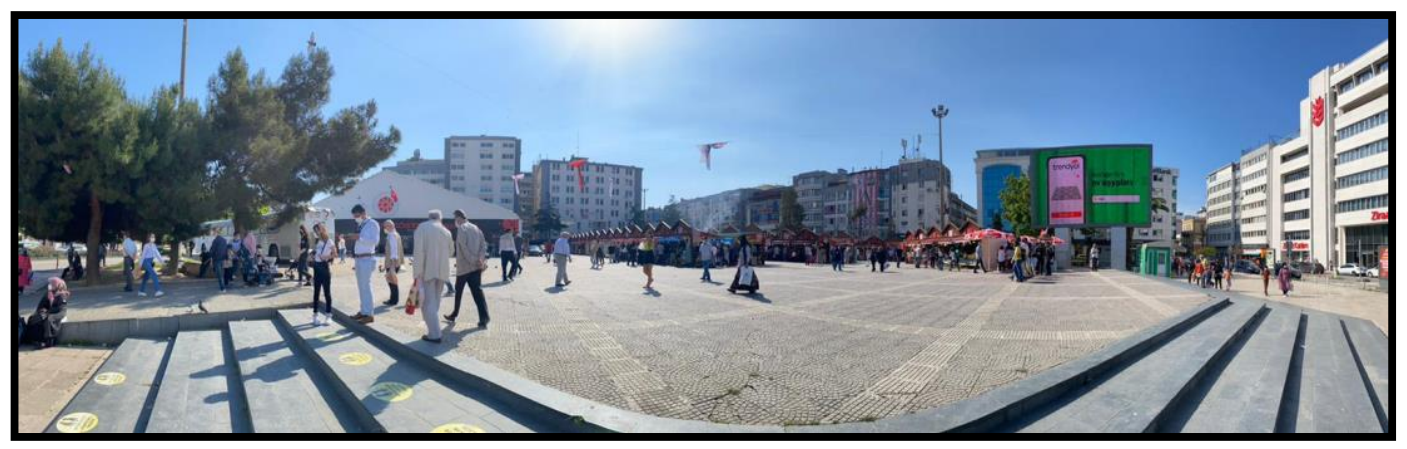

Resim 29. Samsun Kale Mahallesi Cumhuriyet Meydanı (Kaynak: Birnur KÖSE, 2021.) 

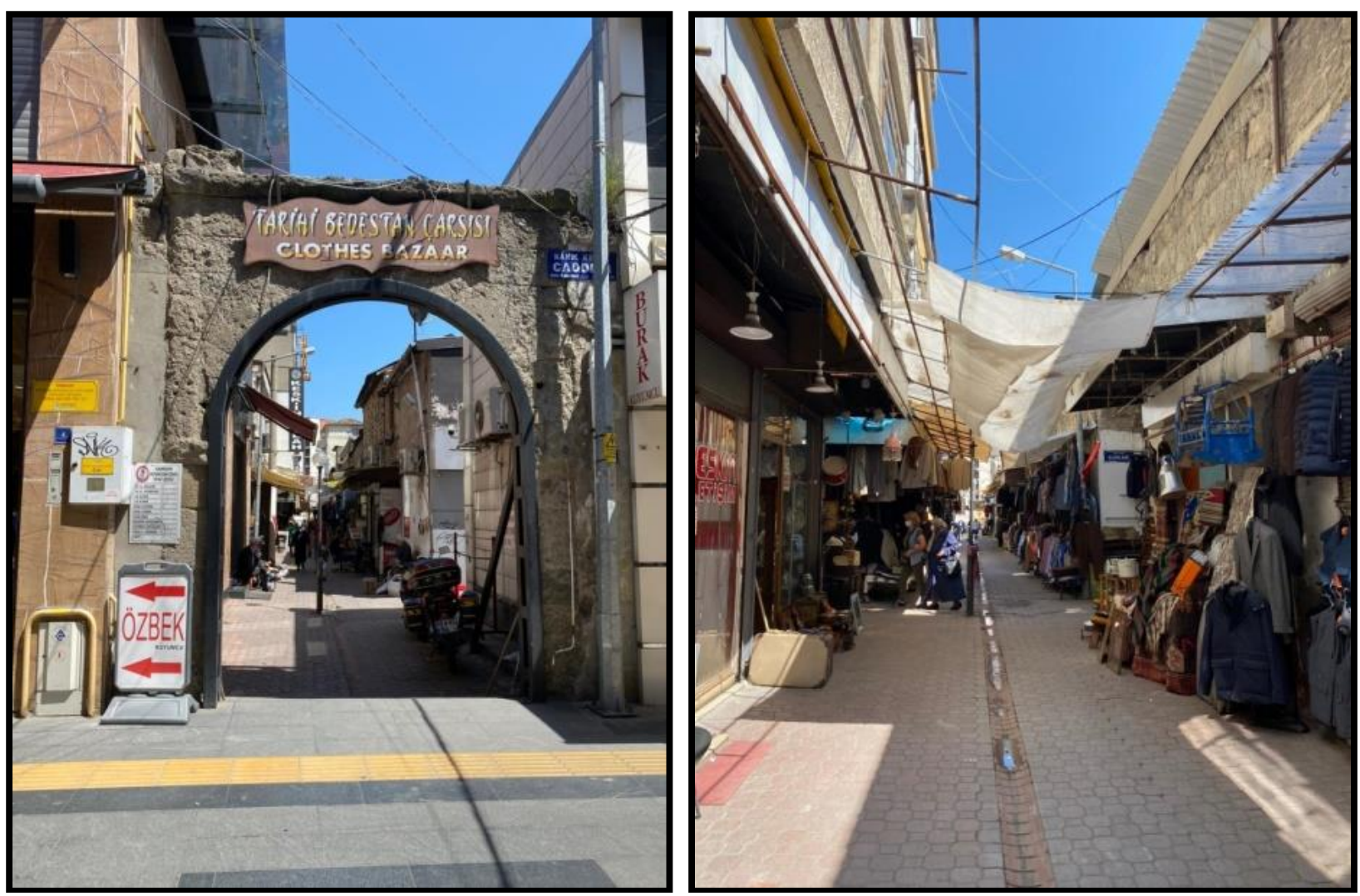

Resim 30-31. Samsun Kale Mahallesi Tarihi Bedesten Çarşısında Gölgelendirme (Kaynak: Birnur KÖSE, 2021.)

\subsection{Yapay Çevre Bileşenleri Bakımından Samsun-Kale Mahallesi}

Alanı yapay çevre özellikleri bakımından daha detaylı inceleyebilmek adına Lynch (1961)'in mekânsal analiz yöntemi doğrultusunda incelenmiştir. Bu nedenle yapay çevre bileşenleri; yollar, dokular ve bölgeler, sınırlar, işaret öğeleri ve odak noktaları olarak değerlendirilmiştir. Kale Mahallesi bölgesi tarihsel süreç içerisinde çeşitli değişimler görmüş ve barındırdığı tarihi dokusunu bu süreçte kaybetmeye başlamıştır. Bu nedenle alanda çok sayıda yapay çevre bileşenleri görülmektedir.

Doku ve bölge özelliklerine bakıldığında; Kale Mahallesinin farklı işlevlere sahip Kuyumcular çarşısı, Mecidiye çarşısı, Bedesten çarşısı, Bulvar AVM, Site Cami çarşısı ve Kasaplar caddesi gibi alanlar detaylı incelendiğinde farklı cadde ve sokakların farklı ticari işlevleri yüklendiği görülmektedir. Mevlevihane caddesinde yer alan kuyumcular [Resim 35], Alparslan sokakta yer alan geleneksel giyim ve ürün dükkanları [Resim 34], Mecidiye çarşısında yer alan giyimayakkabı dükkanları [Resim 33], ağılıklı olarak yemek yeme alanlarının yer aldığı Bulvar AVM [Resim 32], Kasaplar caddesinde yer alan gıda ürünleri dükkanları [Resim 36], Site Merkez çarşısındaki dini ürünlerin satımı, Bedesten çarşısında yaşlı kesime hitap eden giyim dükkanları [Resim 37], Afitap Sokak güzergahında bulunan ayakkabı üretimi ve tadilatlarının yapıldığı pasaj ve çok sayıda çay ocağının, çömlekçilerin bulunduğu Namık Kemal Caddesine bakıldığında bu işlevsel sınıflandırma ortaya çıkmaktadır [Şekil 9]. 


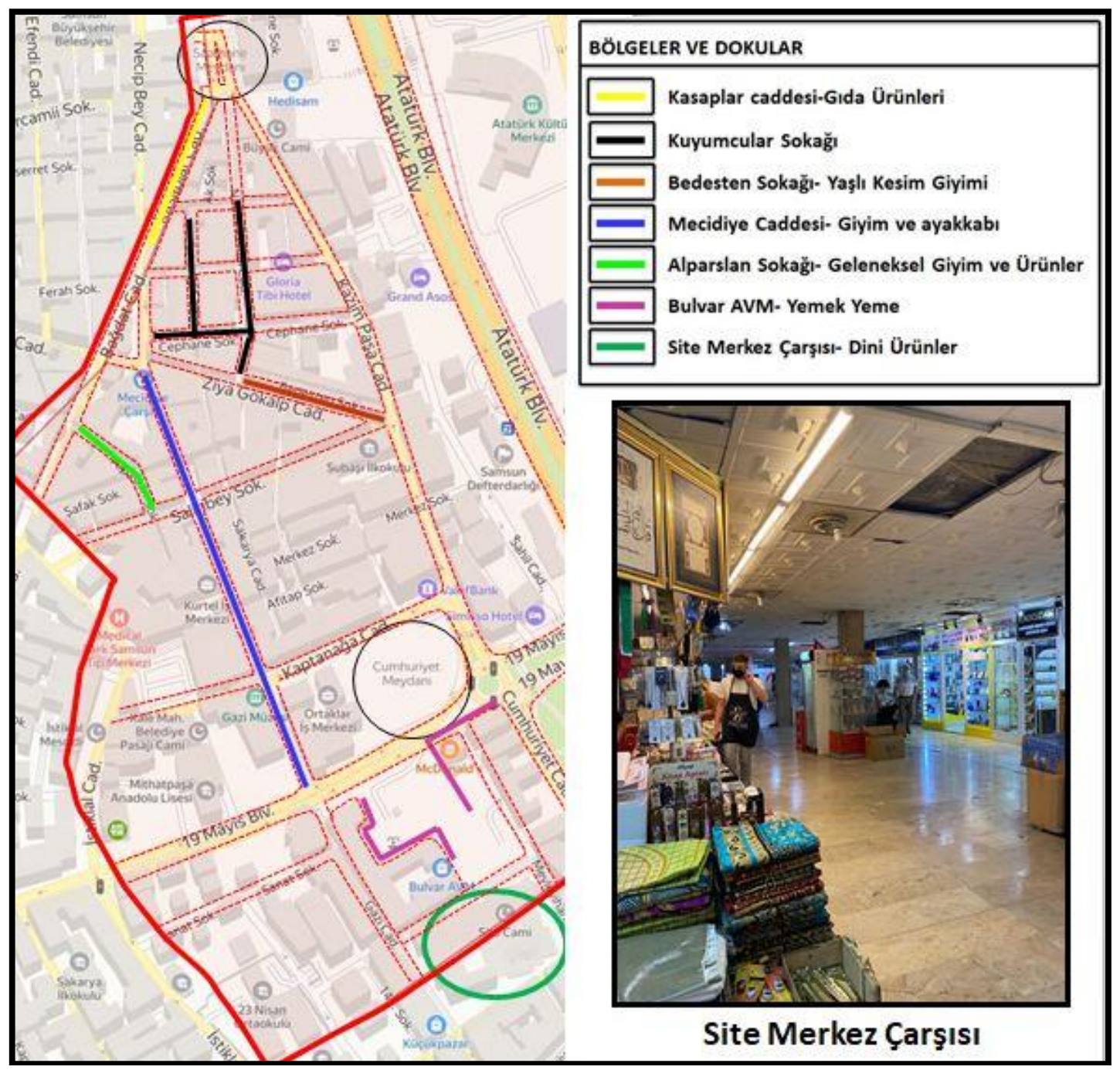

Şekil 9. Kale Mahallesi Lynch Analizi Bölgeler ve Dokular (Kaynak: Birnur KÖSE, 2021)
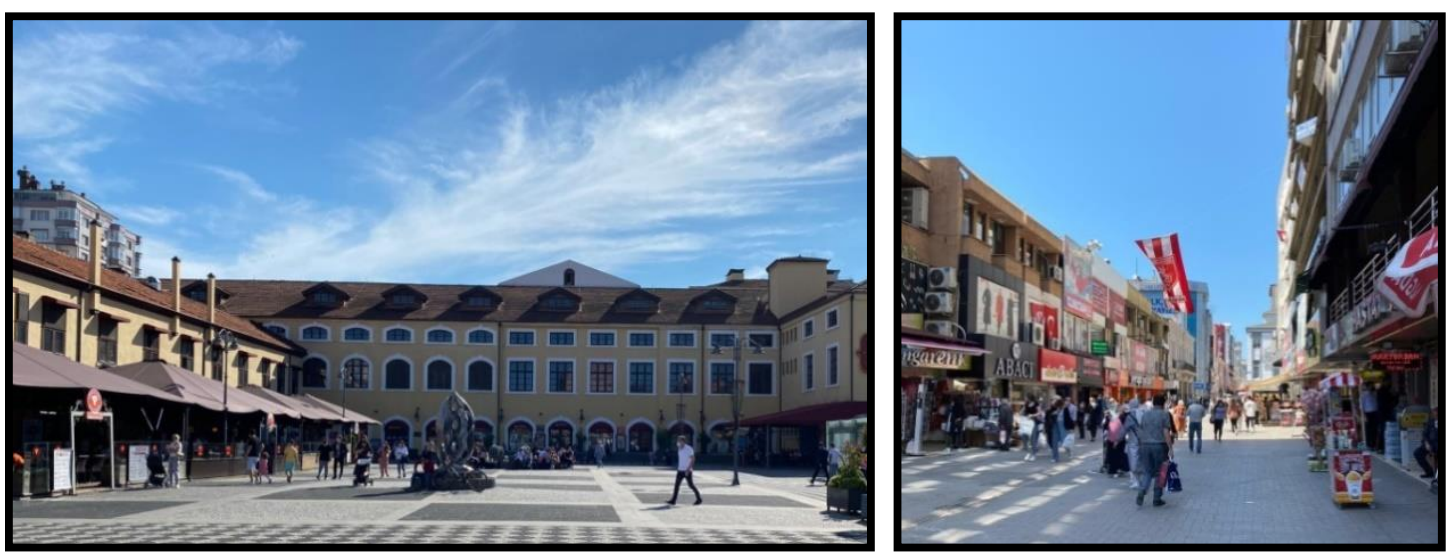

Resim 32-33. Bulvar AVM - Mecidiye Çarşısı (Kaynak: Birnur KÖSE, 2021) 

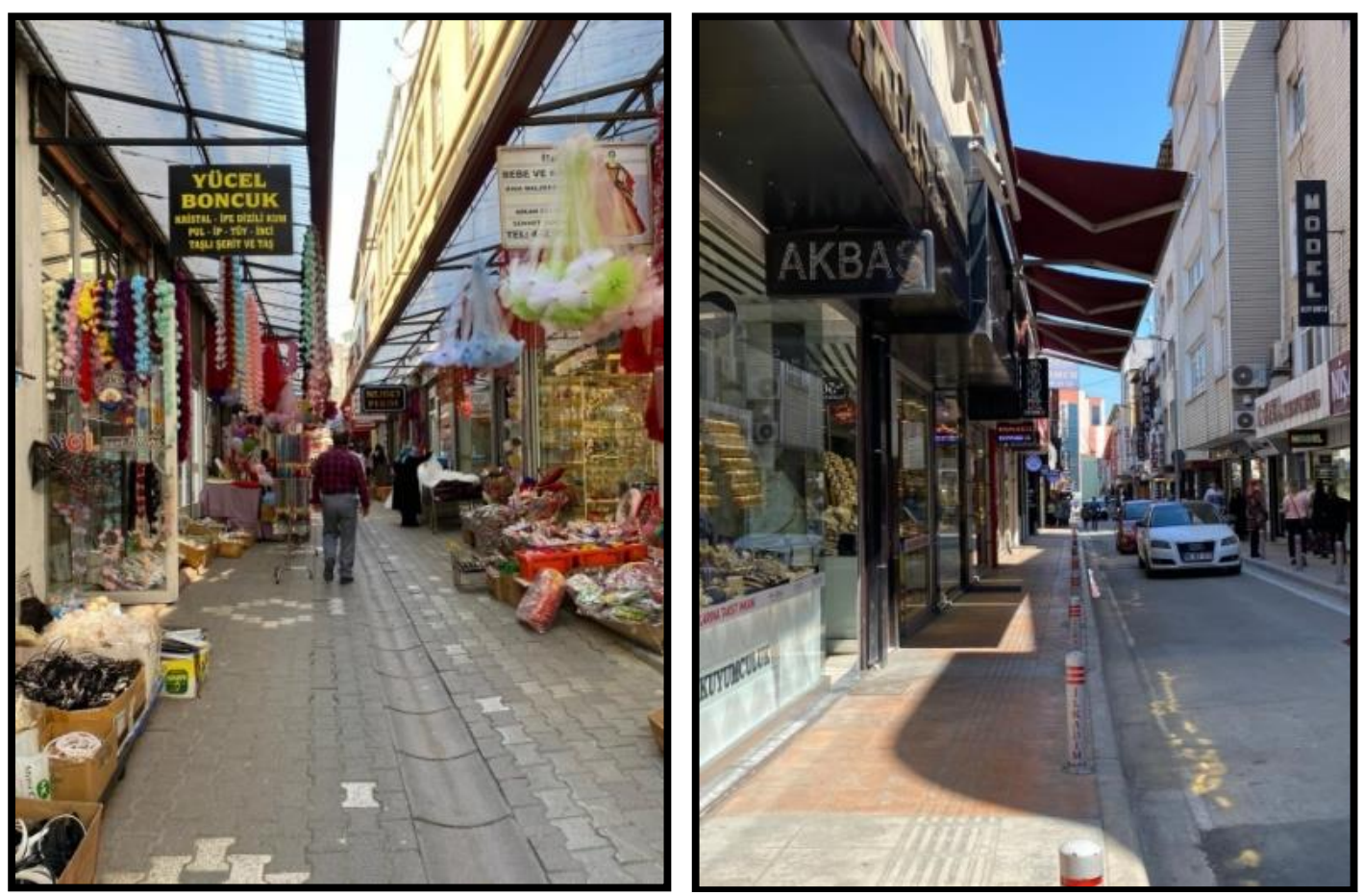

Resim 34-35. Alparslan Sokak - Kuyumcular Çarşısı (Kaynak: Birnur KÖSE, 2021)
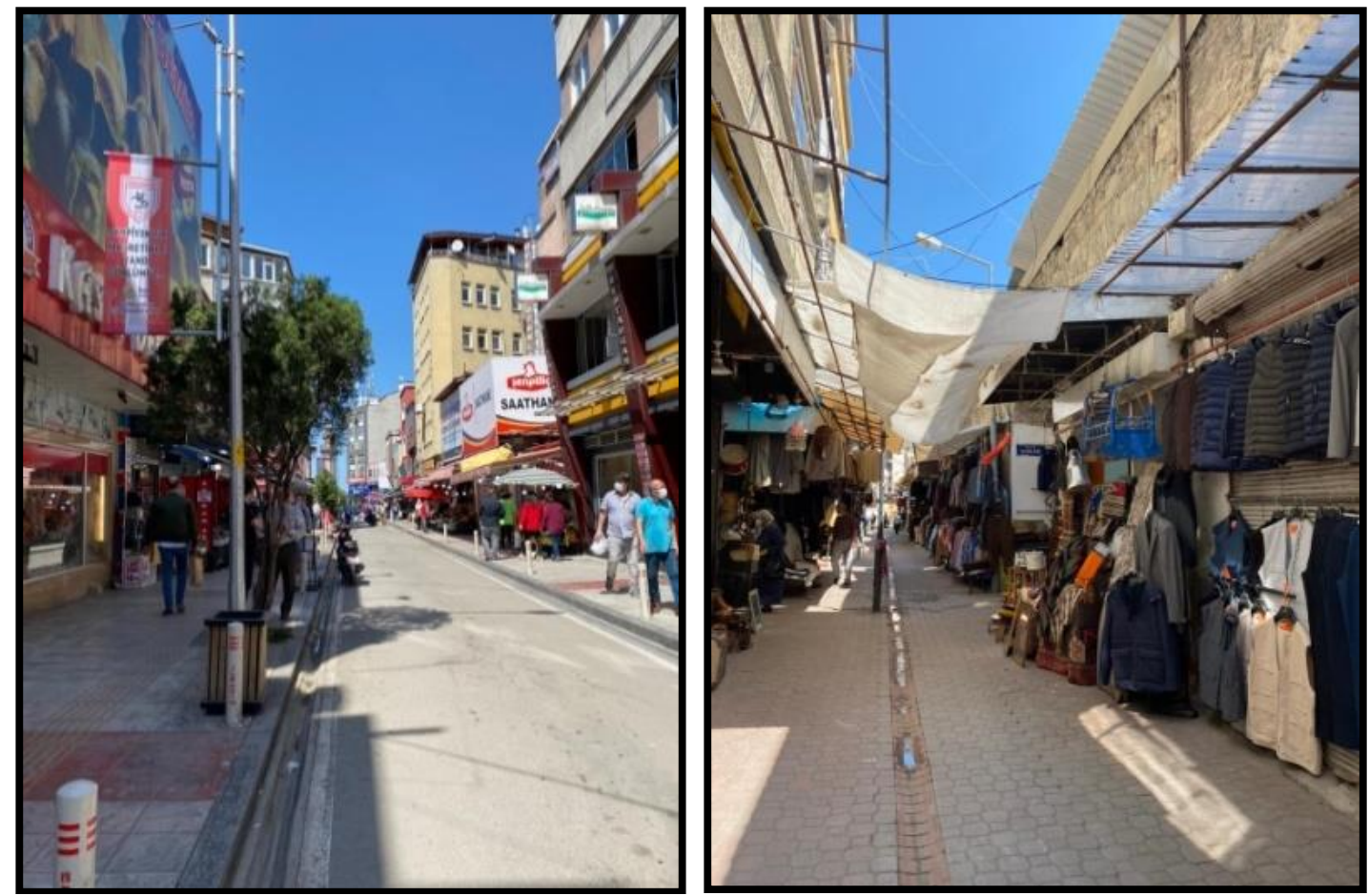

Resim 36-37. Kasaplar Caddesi - Bedesten Çarşısı (Kaynak: Birnur KÖSE, 2021) 


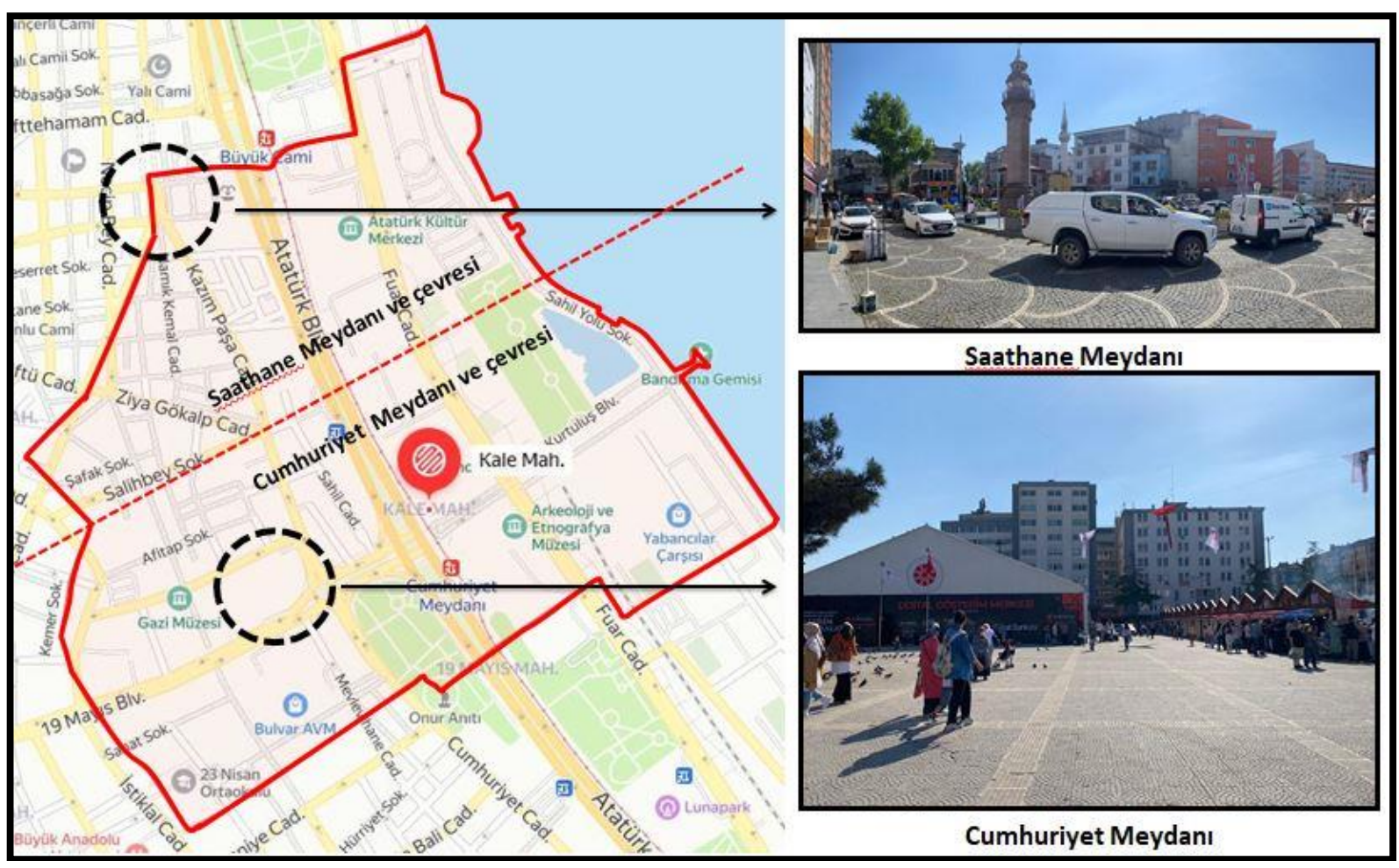

Şekil 10. Kale Mahallesi İki Önemli Odak Noktası (Cumhuriyet Meydanı-Saathane Meydanı)

(Kaynak: Birnur KÖSE, 2021)

Çalışma Kapsamındaki Kale Mahallesinde yer alan, akılda kalıcılığı ve tariflemeyi sağlayan odak noktaları Cumhuriyet Meydanı ve Saathane Meydanı olarak belirlenmiştir ve alan Cumhuriyet Meydanı ve çevresi, Saathane Meydanı ve çevresi olarak iki farklı başlıkta incelenmiştir [Şekil 10].
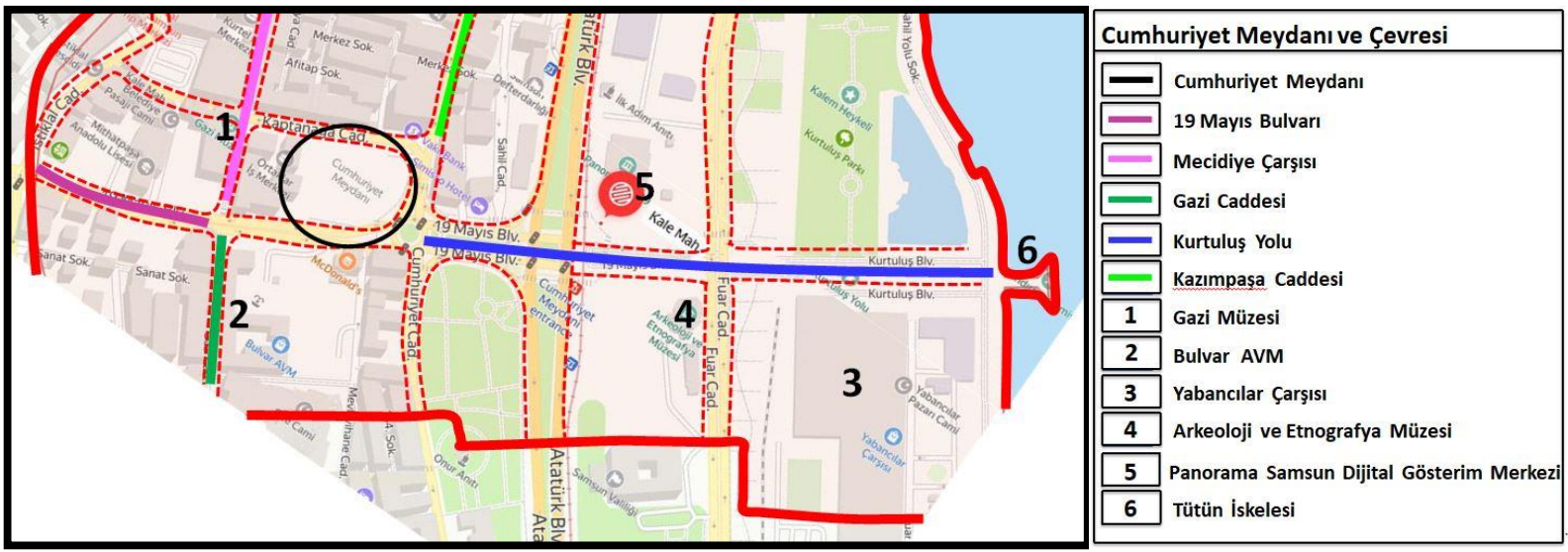

Şekil 11. Cumhuriyet Meydanı ve Çevresi Bölgesi.

İlk olarak incelenen Cumhuriyet Meydanı [Resim 38-39] Kanuni Sultan Süleyman dönemi itibariyle Samsun kentinin mezar alanı olarak kullanılmış ve mezarlı̆̆ın kaldırılması ile tarihte duvarlarla çevrili mekan halini almıştır (Sarısakal, 2002). Tarihsel süreç içerisinde tasarım değişikliği yaşayan meydan yaya sirkülasyonunun düğüm noktasıdır ve halk için hem toplanma hem buluşma hem de dinlenme alanı durumundadır. Meydan, kent kimliğini etkileyen müze yapılarından biri olan Gazi Müzesinin bulunduğu Mecidiye çarşısının [Resim 40], Samsun kentinin önemli imgelerinden olan tarihi Reji Tütün Fabrikası'nın restorasyonuyla oluşturulan günümüzdeki Bulvar AVM'nin 
bulunduğu Gazi caddesinin ve çok sayıda tescilli tarihi dokuya sahip Kazımpaşa caddesinin [Resim 41] bir araya geldiği ortak bir noktadır. Ayrıca meydanın kuzeyinde, sahil bölgesinde kalan Samsun Yabancılar çarşısı [Resim 42-43], Arkeoloji ve Etnografya Müzesi, Panorama Samsun Dijital Gösterim Merkezi [Resim 47], Kurtuluş yolu ve Tütün İskelesi [Resim 44-45] meydanla bütünleşen öğelerdendir [ŞSekil 11]. Samsun'un Mustafa Kemal Atatürk'ün milli mücadeleyi başlatmak üzere ayak bastığı kent oluşunu simgeleyen Kurtuluş yolu ve günümüzde Atatürk ve silah arkadaşlarının canlandırılmasının yapıldığı iskele [Resim 46] Samsun kentinin kimliğini oluşturan önemli faktörlerdendir.

Kale Mahallesi içerisinde yer alan Cumhuriyet Meydanının çevresinde Samsun kentinin simgesi haline gelen iki anıt mevcuttur. Bunlardan biri Atatürk'ün doğumunun 100. yılını simgeleyen İlkadım Anıtıdır. İkincisi ise Atatürk Parkı içerisinde yer alan 19 Mayıs 1919'un anısına yapılan kentin simgesi olmuş Onur Anıtıdır [Resim 48-49-50-51].

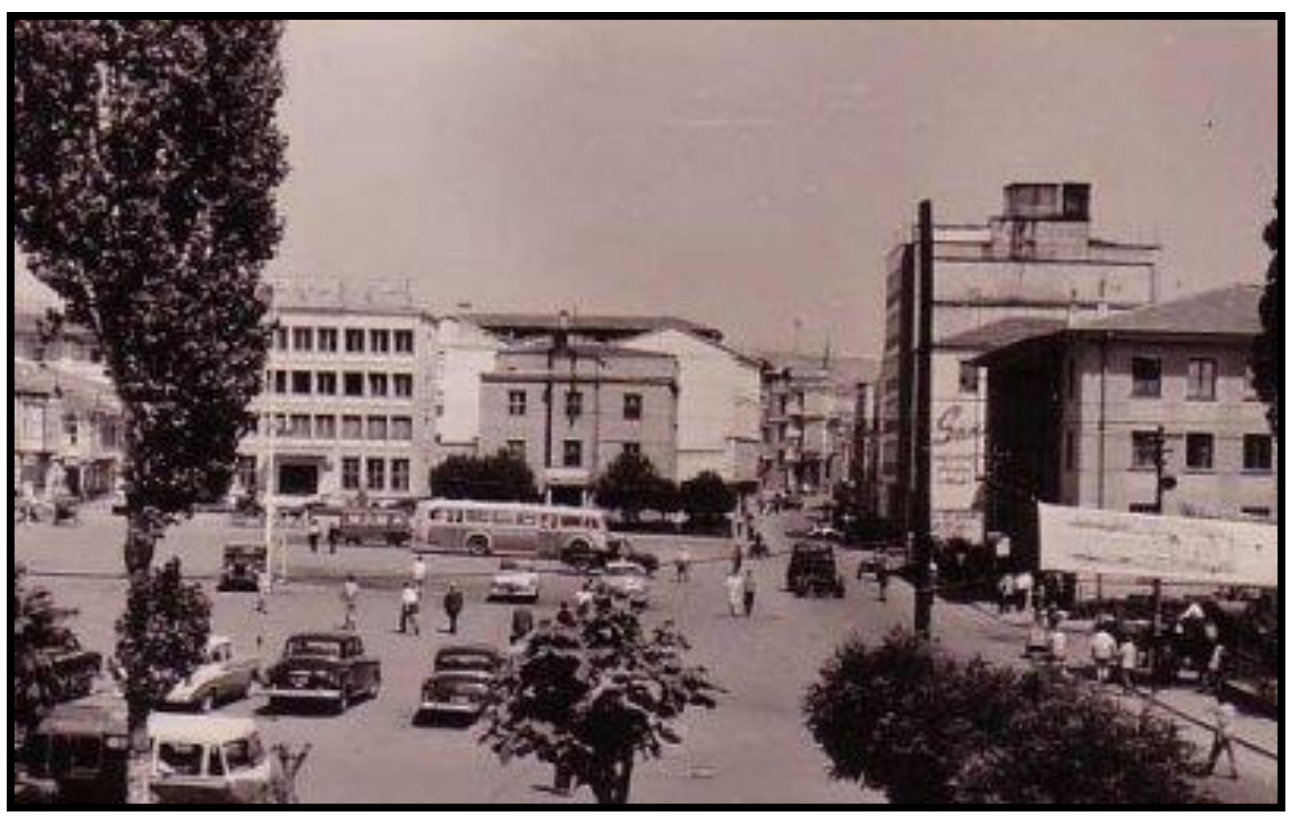

Resim 38. Cumhuriyet Meydanı (Kaynak: Samsun İl Kültür ve Turizm Müdürlüğü Fotoğraf Arşivi. )

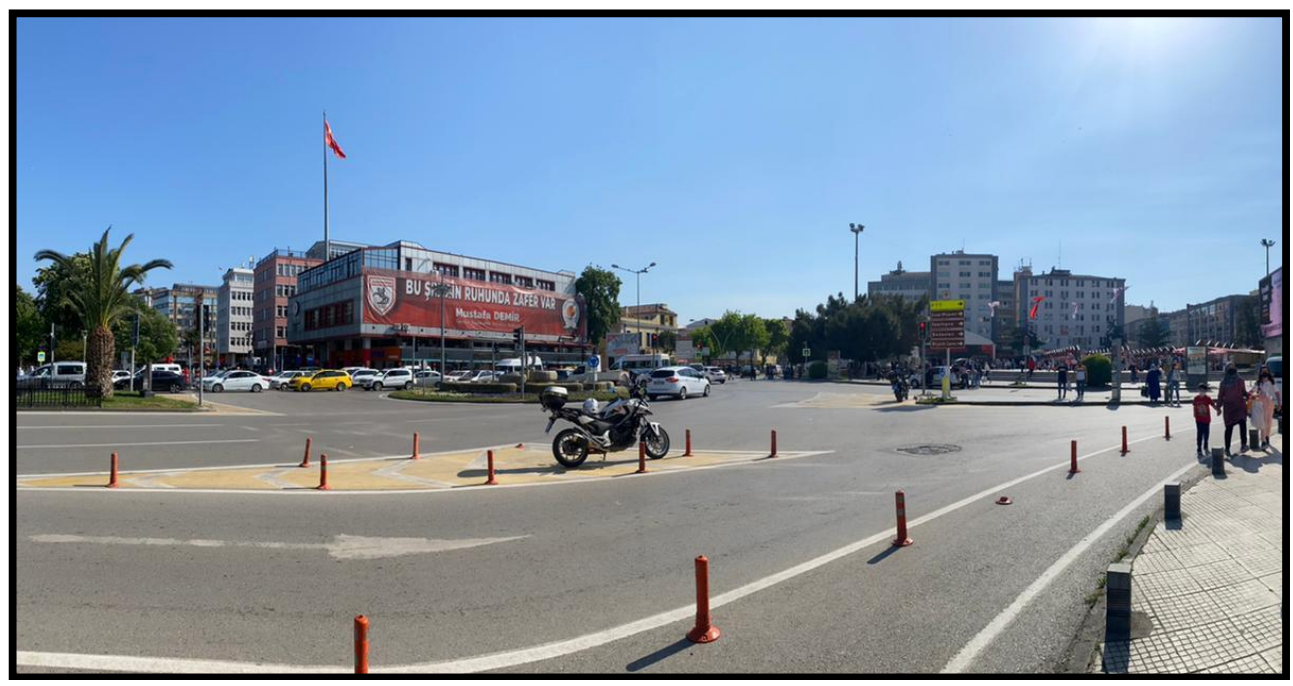

Resim 39. Cumhuriyet Meydanı (Kaynak: Birnur KÖSE, 2021) 

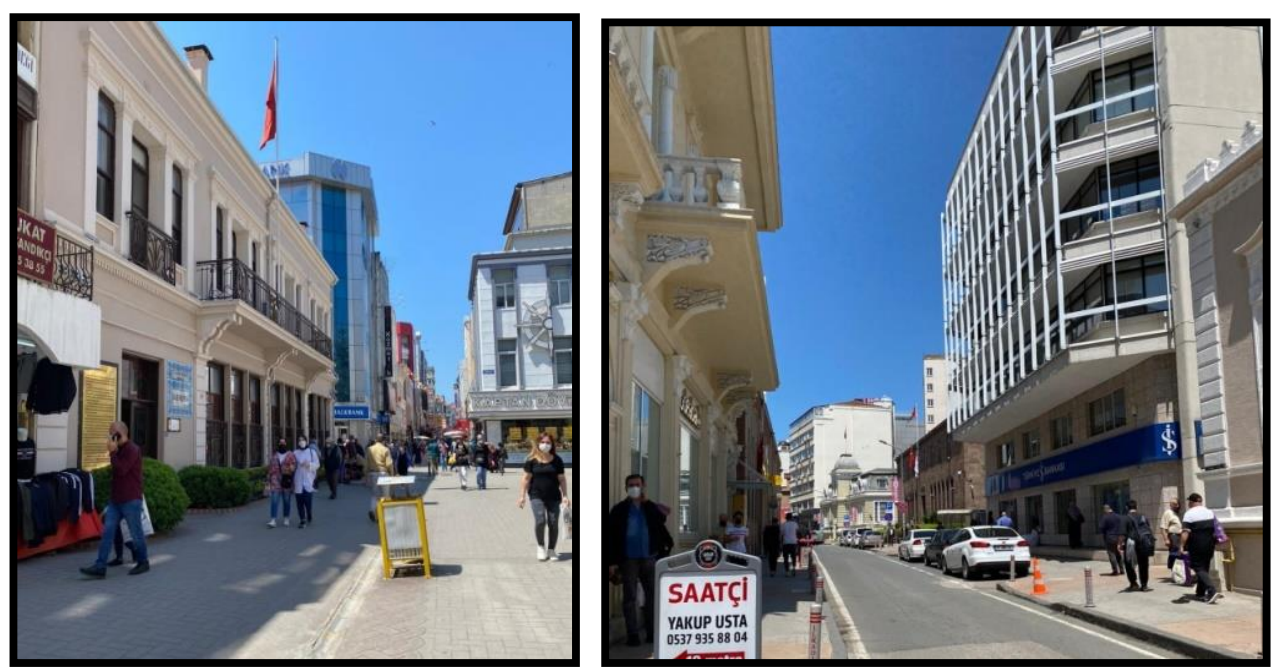

Resim 40-41. Mecidiye Çarşısı Gazi Müzesi - Kazımpaşa Caddesi (Kaynak: Birnur KÖSE, 2021)
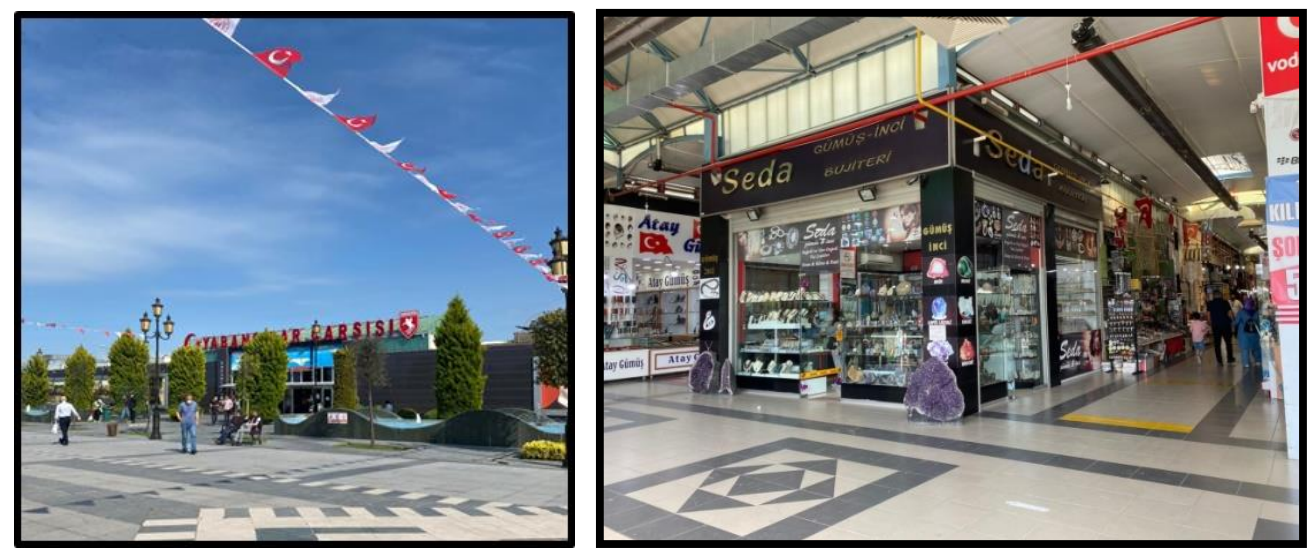

Resim 42-43. Yabancılar Çarşısı (Kaynak: Birnur KÖSE, 2021)
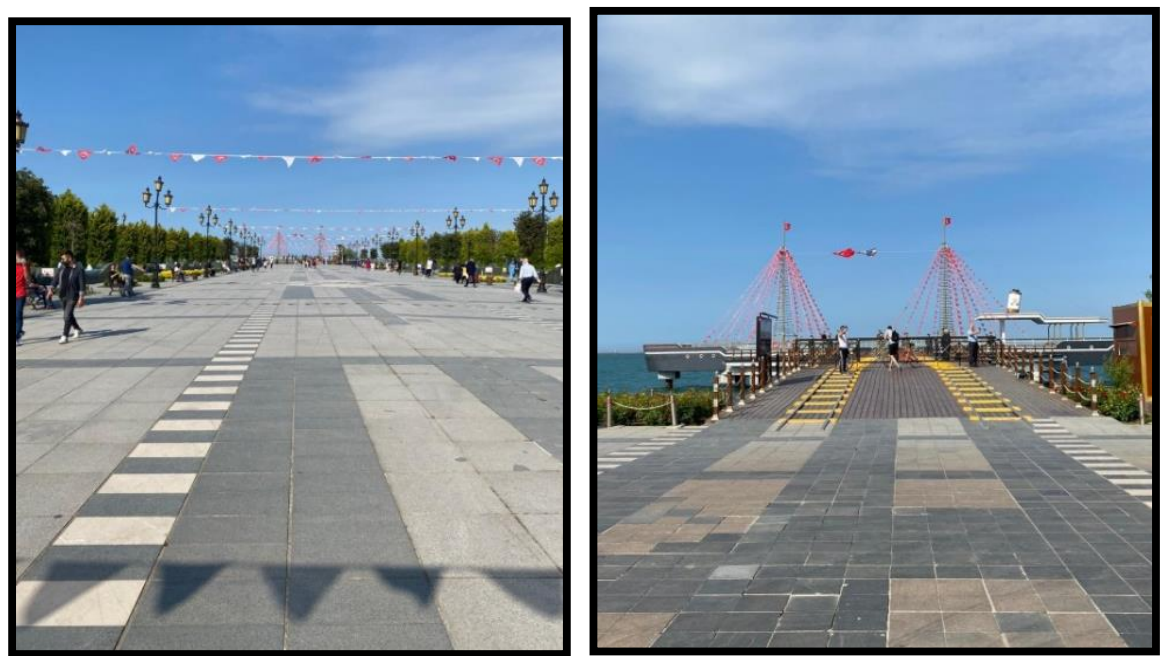

Resim 44-45. Kurtuluş Yolu (Kaynak: Birnur KÖSE, 2021) 

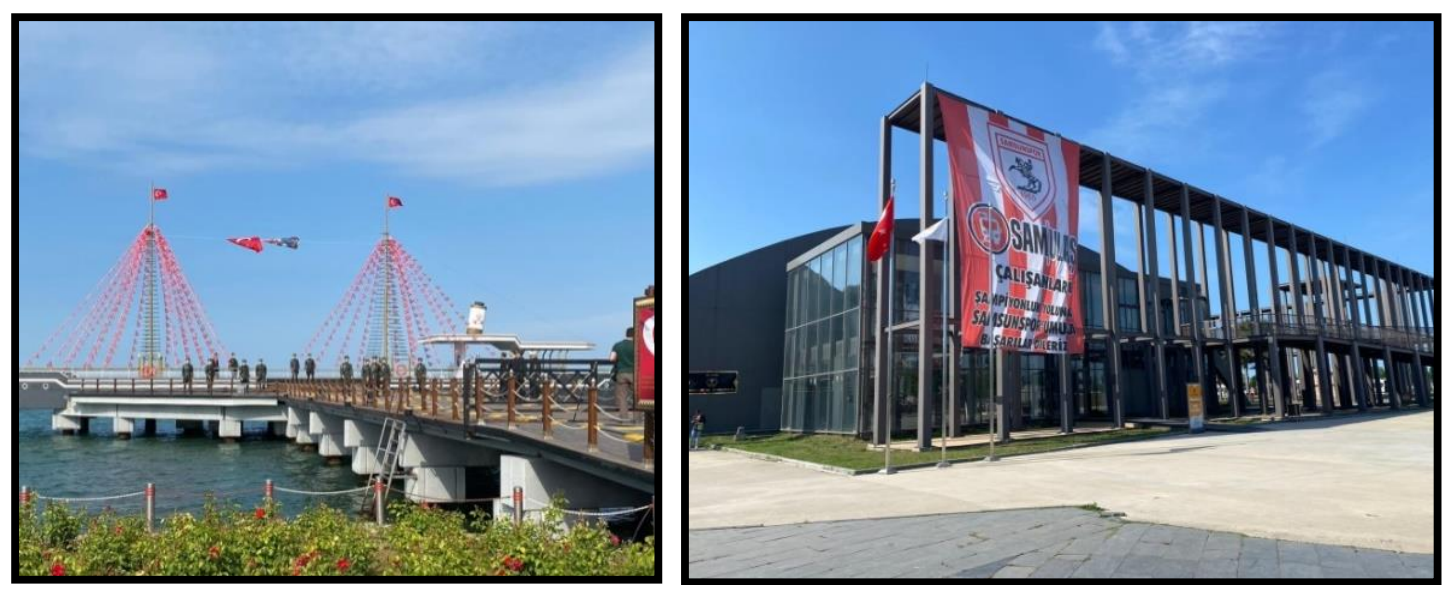

Resim 46-47.Tütün İskelesi- Panorama Samsun Dijital Gösterim Merkezi (Kaynak: Birnur KÖSE, 2021)
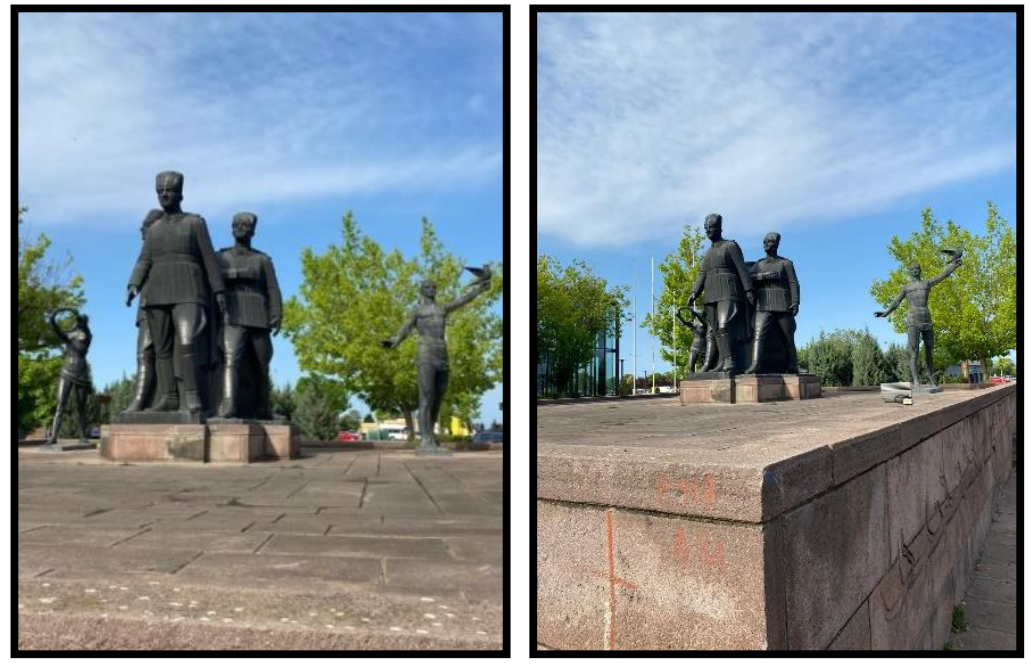

Resim 48-49. İlkadım Anıtı (Kaynak: Birnur KÖSE, 2021)
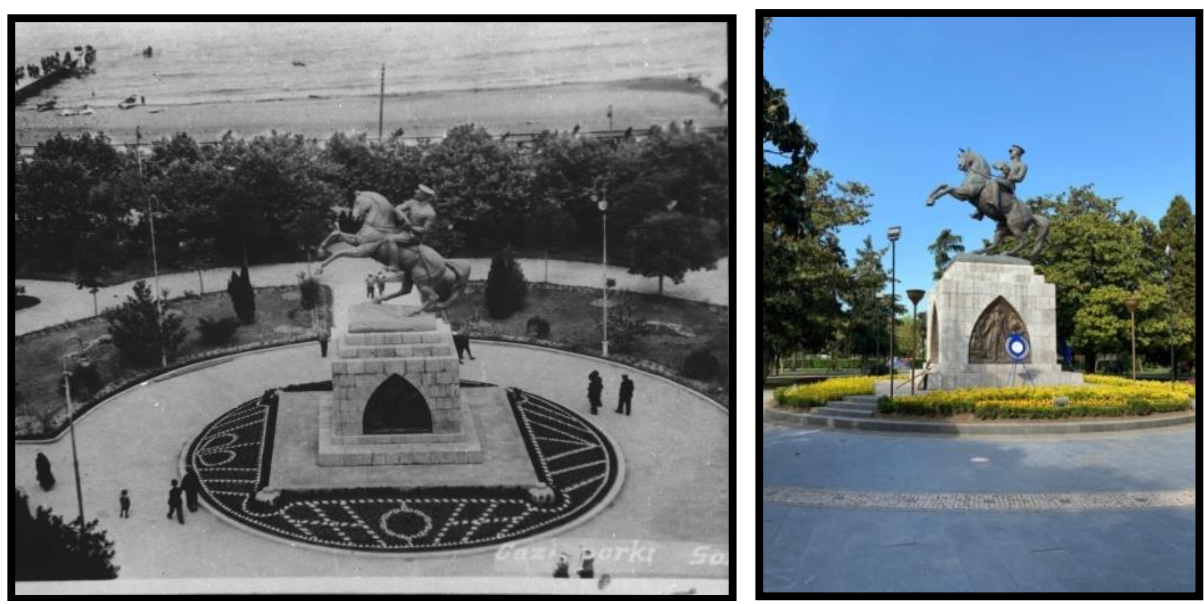

Resim 50-51. Onur Anıtı (Kaynak: Samsun İl Kültür ve Turizm Müdürlüğü Fotoğraf Arşivi - Birnur KÖSE, 2021) 


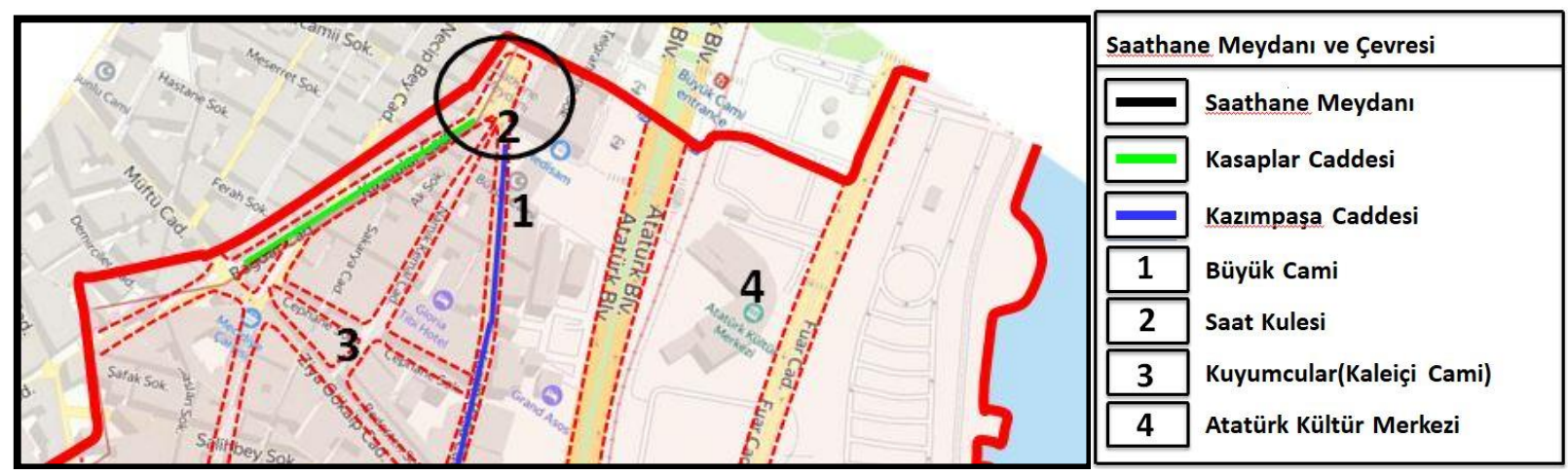

Şekil 12. Saathane Meydanı ve Çevresi Bölgesi.

İkinci olarak ele alınan ve önemli bir tarihi dokuya sahip olan Saathane Meydanı [Resim 52-53-54-55] tarihte saat kulesi yapılmadan önceki dönemlerde Trabzon Vilayet Salnamelerine göre İskele caddesi ya da Meyve Pazarı olarak adlandırılmışıır. Daha sonraki dönemlerde meydanın simgesi haline gelen Saat Kulesinin yapımıyla meydan günümüzdeki adını almıştır(Sarısakal, 2002). Meydan araç ve yaya sirkülasyonunun oldukça yoğun olduğu ve genellikle yaşlı nüfusun baskın olduğu bir alandır. Meydanın yakın çevresinde bulunan Büyük Cami meydan ile bütünleşen önemli öğelerden biridir [Resim 56]. Aynı zamanda cami çevresinde, önemli kalıntılardan biri olan ve bazı bölgelerde korunabilmiş olan, kentin geçmişini oluşturan Samsun Kalesinin kalıntılarını da günümüzde hala görmek mümkündür [Resim 57]. Kuyumcular çarşısı ve bedesten çarşısının birleşim noktasında yer alan, günümüze ulaşıncaya kadar çeşitli değişimler yaşamış Kuyumcular Cami(Kaleiçi Cami) de konumuyla önemli bir diğer camidir [Resim 5859]. Ayrıca Atatürk Kültür Merkezide bu bölgede değerlendirilen odak noktalarındandır [Şekil 12].

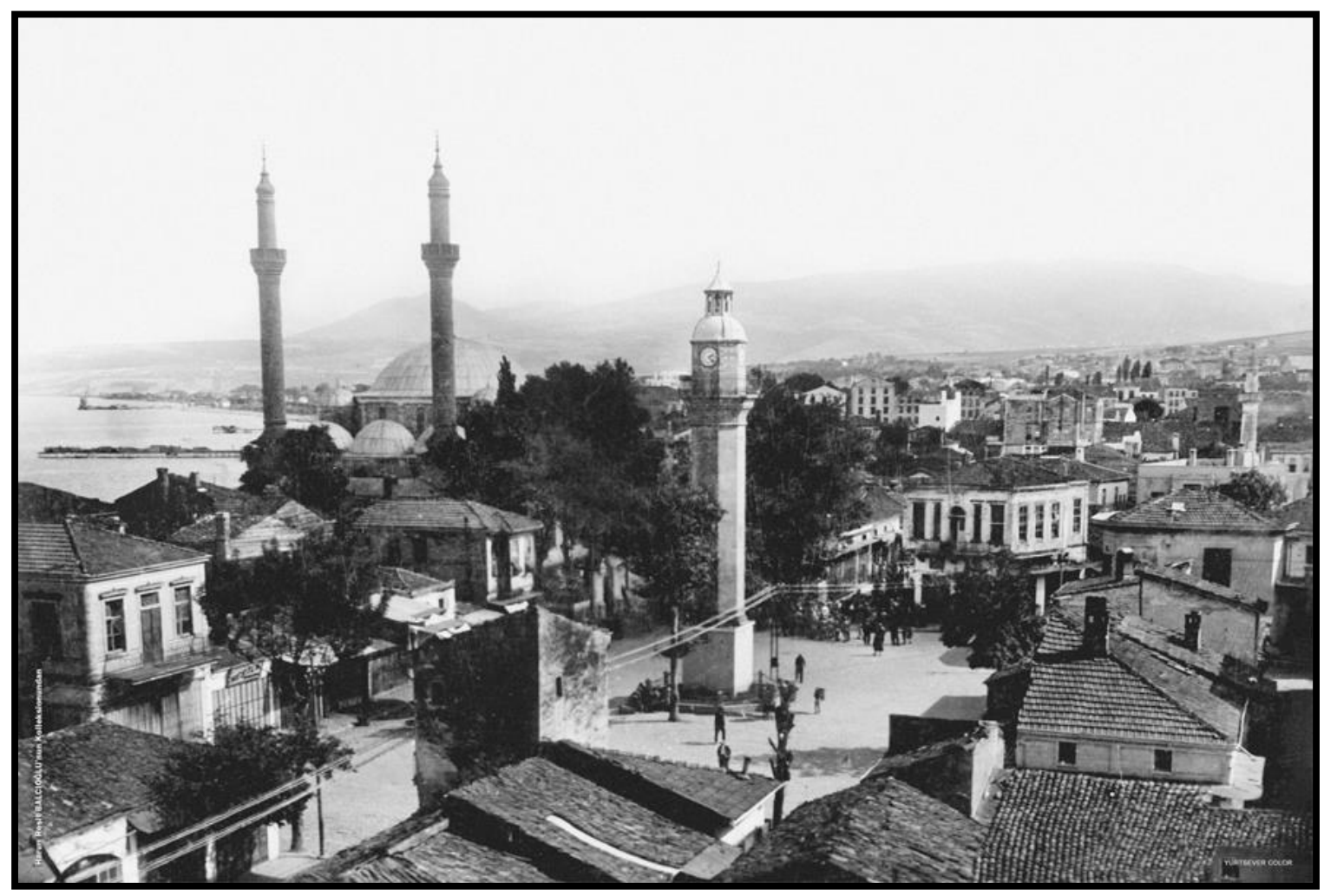

Resim 52. Saathane Meydanı (Kaynak: Samsun İl Kültür ve Turizm Müdürlüğü Fotoğraf Arşivi.) 


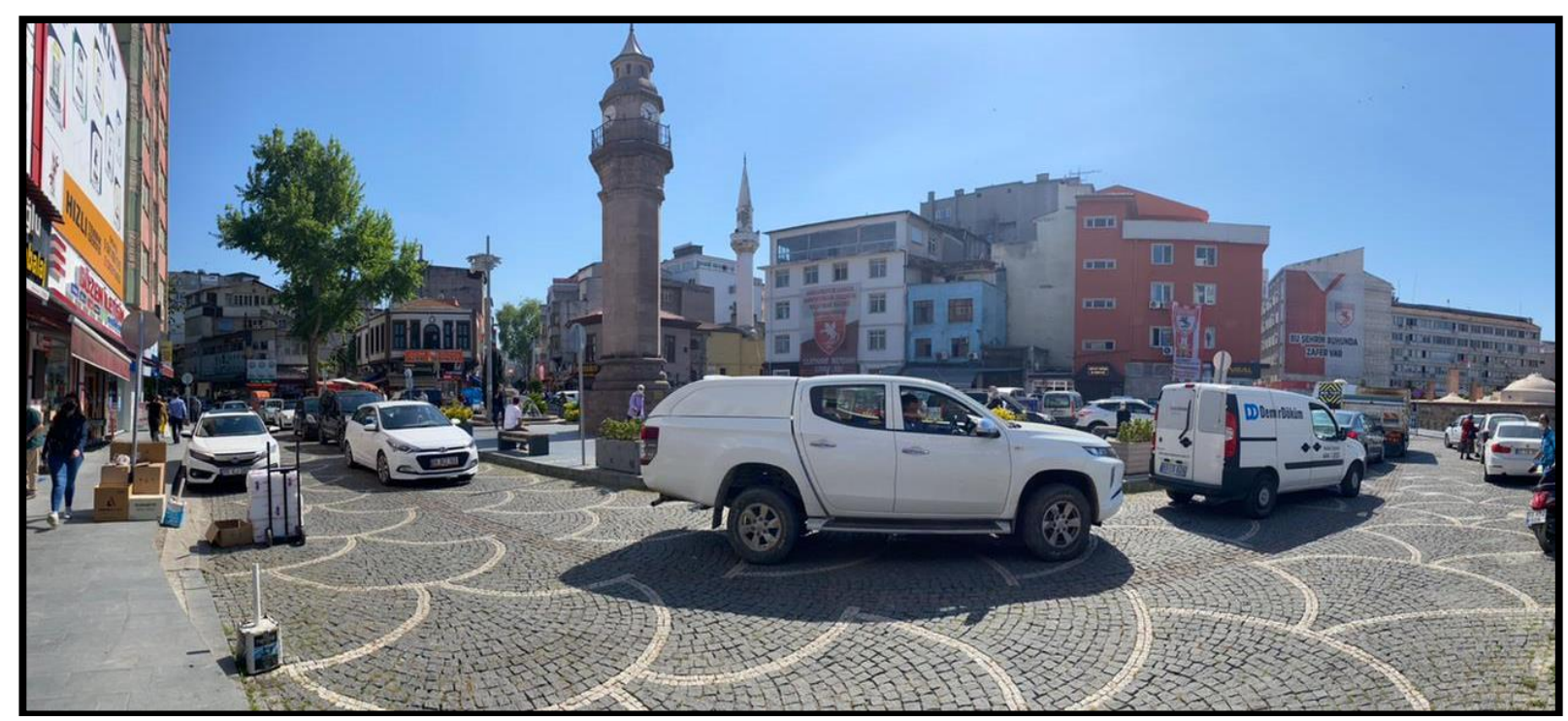

Resim 53. Saathane Meydanı (Kaynak: Birnur KÖSE 2021.)
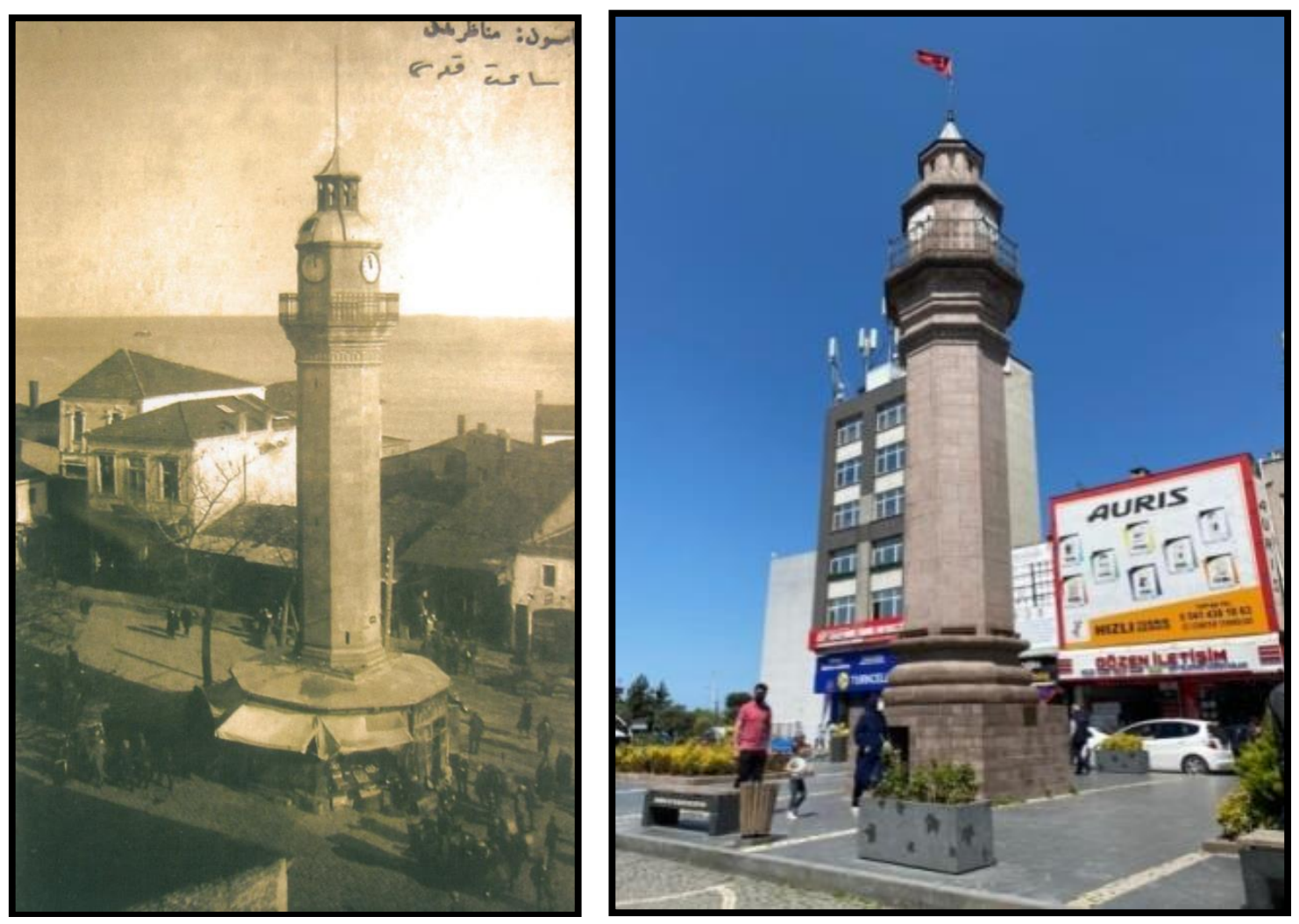

Resim 54-55. Saathane Meydanı Saat Kulesi (1890) - Saathane Meydanı Saat Kulesi (2021).

(Kaynak: Samsun İl Kültür ve Turizm Müdürlüğü Fotoğraf Arşivi - Birnur KÖSE, 2021) 

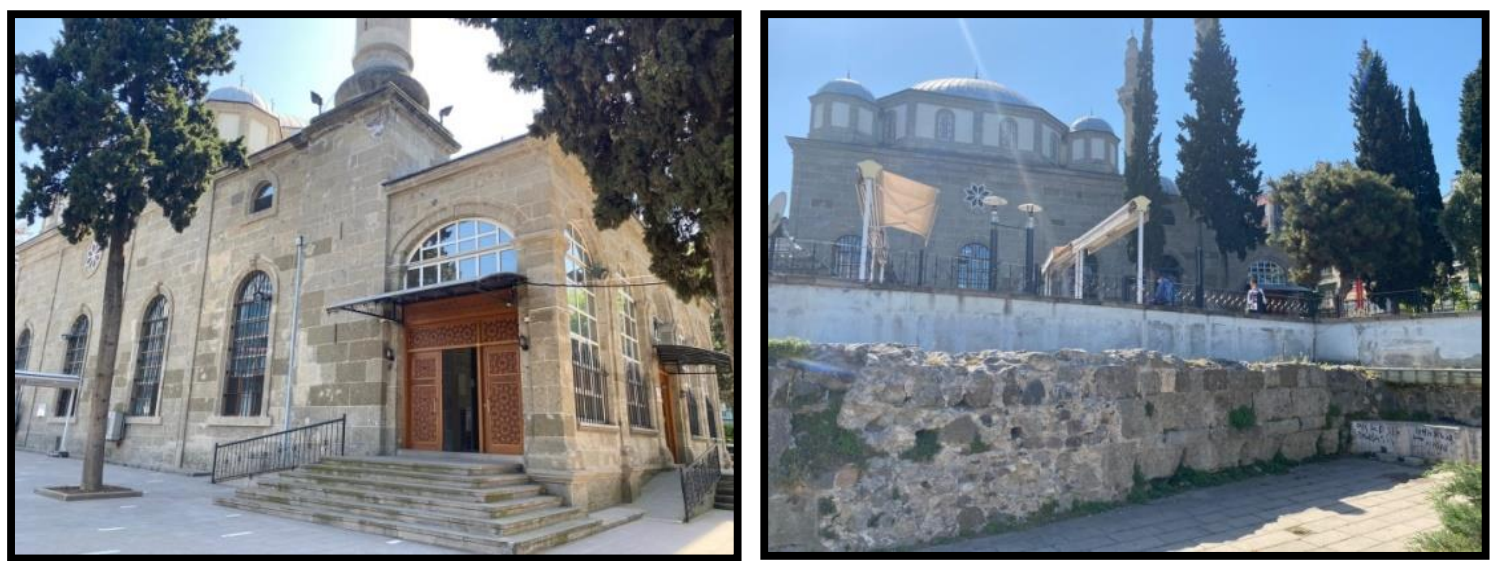

Resim 56-57. Samsun Kale Mahallesi Büyük Cami ve Sur Kalıntıları (Kaynak: Birnur KÖSE, 2021)

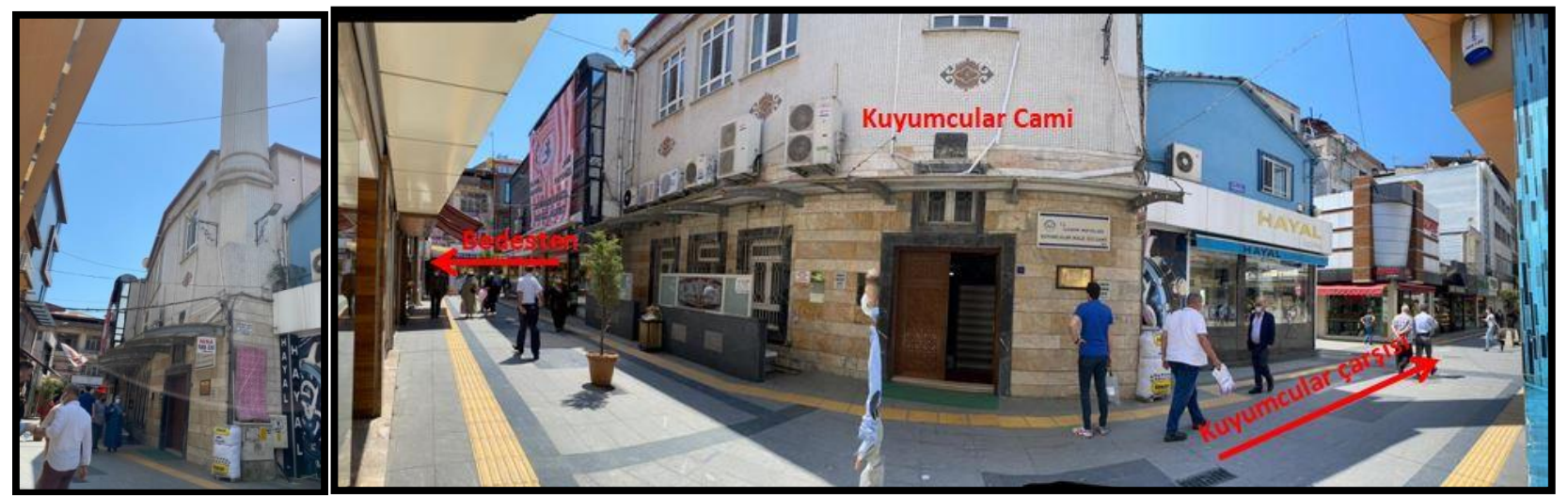

Resim 58-59. Samsun Kale Mahallesi Kuyumcular(Kale İçi) Cami (Kaynak: Birnur KÖSE, 2021)

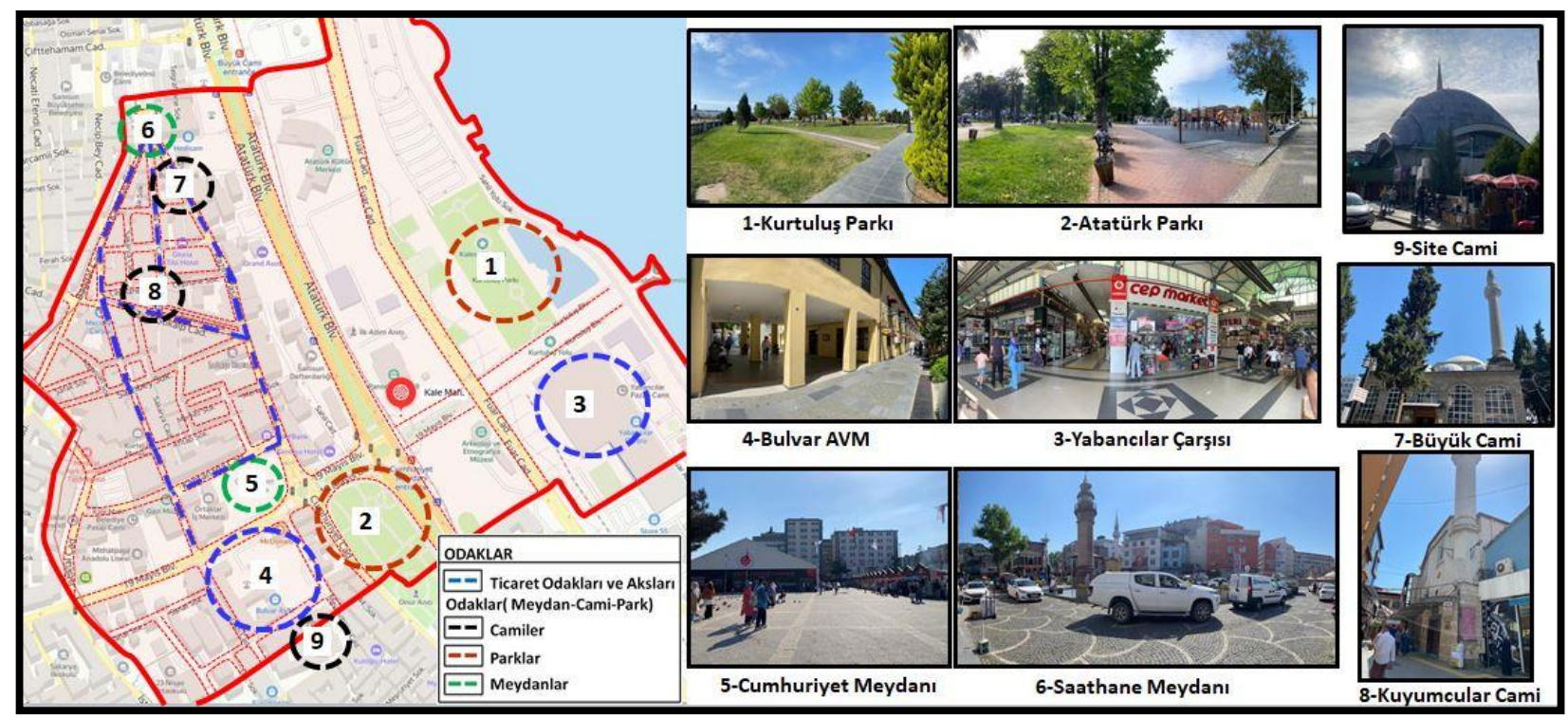

Şekil 13. Kale Mahallesi Bölgesi Lynch Analizi Odaklar. 
Çalışma alanı olan Kale Mahallesi cami, park ve meydanlar gibi çeşitli odak noktalarını barındırması ve tarihi ticari merkez olmasından dolayı farklı ticari alanları barındırmaktadır [Şekil 13].

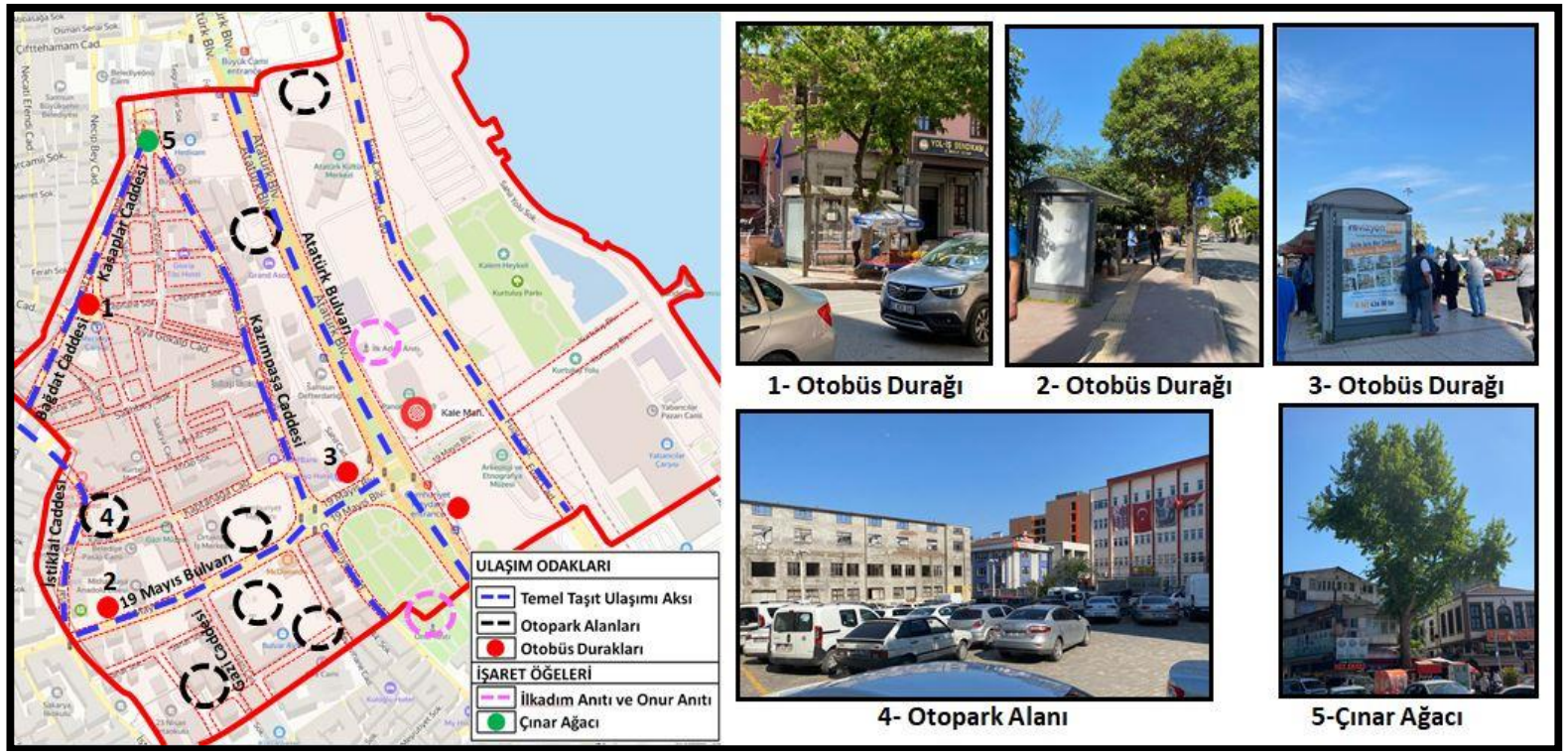

Şekil 14. Kale Mahallesi Bölgesi Lynch Analizi Ulaşım Odakları ve İşaret Öğeleri.

Kale Mahallesi içerisinde bulunan odak noktası olarak belirlenen Cumhuriyet Meydanı ve Saathane Meydanı arasındaki bağlantıyı sağlayan aks; Kazımpaşa caddesi, Kasaplar caddesi, Bağdat caddesi, İstiklal caddesi ve 19 Bulvarının oluşturduğu ağdır. Kale Mahallesi incelendiğinde taşıt ulaşımı yoğunluğunun en fazla olduğu güzergahların cumhuriyet meydanından başlayan 19 Mayıs bulvarı, Atatürk bulvarı, Kazımpaşa caddesi, Bağdat caddesi ve İstiklal caddesinin olduğu görülmektedir. Yaya yoğunluğunun fazla olduğu alanlar özellikle Gazi caddesi olmak üzere Kazımpaşa caddesi, Bağdat caddesi ve İstiklal caddesidir [Şekil 14].

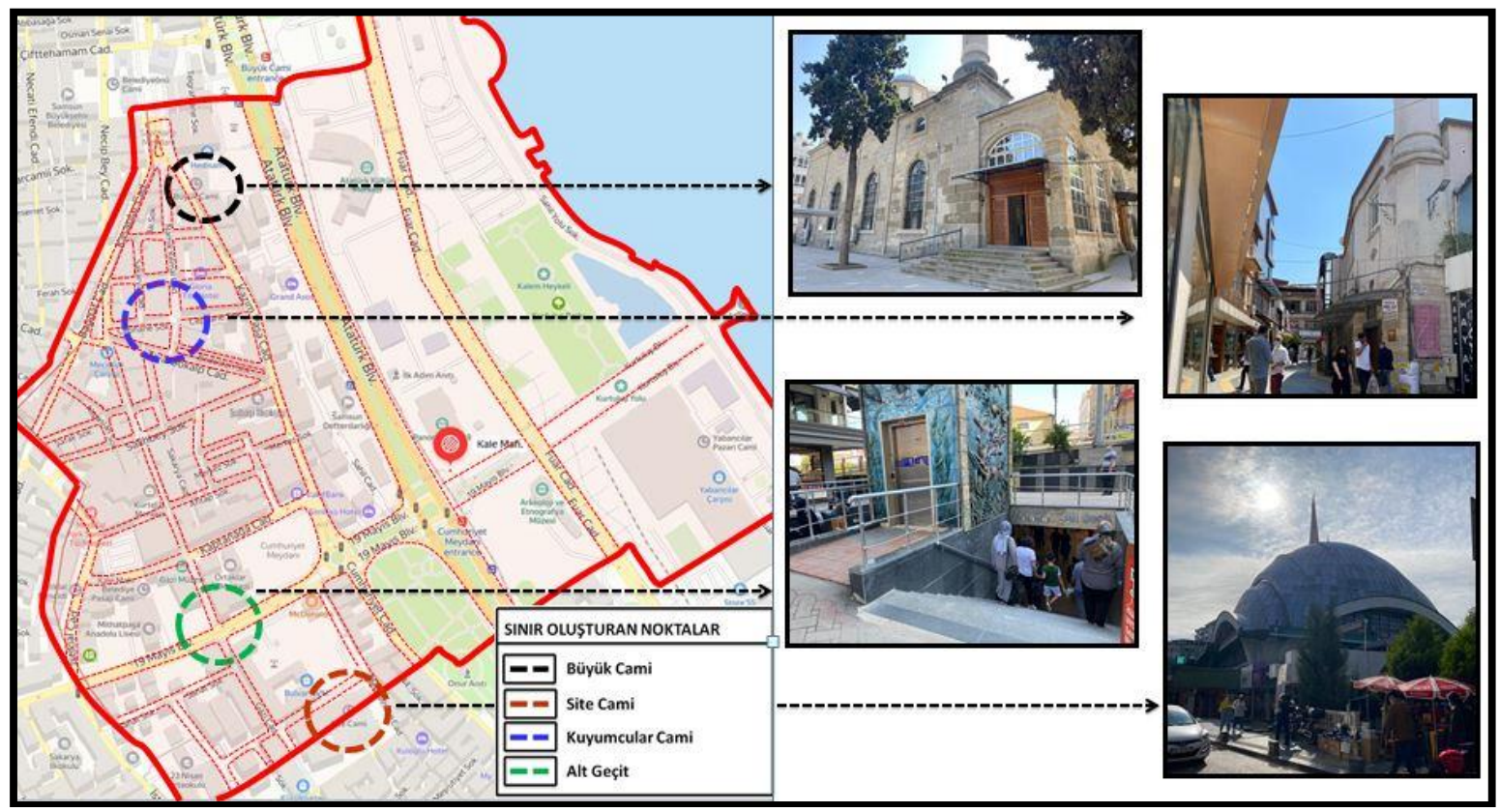

Şekil 15. Kale Mahallesi Bölgesi Lynch Analizi Sınır Noktaları. 
Saathane Meydanı sınırını oluşturan Büyük Cami, Mecidiye çarşısı ve Bulvar AVM ayrımını sağlayan alt geçit, Bulvar AVM başlangıç noktasını oluşturan Site cami ve kuyumcular çarşısı ile bedesten çarşısının birleşim noktasında yer alan Kuyumcular cami çalışma alanı içerisindeki sınır noktalarını oluşturmaktadır [Şekil 15].

Kısaca çalışma kapsamında ele alınan alanın çevresel kimlik bileşenlerine bakıldığında; eğimli, yokuş alanlar, caddeler ve sokakların olduğu ve su varlığının tarihsel süreç içerisinde kaybedildiği görülmüştür. Karadeniz iklim özelliklerini taşıyan çalışma alanında kullanıcılar doğrultusunda esnaf tarafından dükkan önlerinde doğal yöntemler ile gölgelendirme yerine yapay gölgelikler kullanılmıştır, yoğun bir yaya sirkülasyonuna sahip olan meydanlarda ise doğal doku kullanılmamış bunun yerine kentsel mobilyalar tercih edilmiştir; sıklıkla ahşap oturma elemanları kullanılmıştır. Çalışma alanı, doku ve bölge bakımından incelendiğinde; farklı sokak ve caddelerin farklı ticari işlevlere hizmet ettiği görülmüştür. Çalışılan alan içerisindeki en önemli odak noktaları Saathane Meydanı ve Cumhuriyet Meydanı olarak belirlenmiştir. Alanın sınır noktalarını ise farklı işlevlerdeki ticaret alanlarını birbirinden ayıran Büyük Cami, alt geçit, Site Cami ve Kuyumcular Cami oluşturmaktadır [Tablo 1].

\begin{tabular}{|c|c|c|c|c|c|c|}
\hline \multicolumn{7}{|c|}{ KENTSEL KIMLIKK BILEŞENLERI } \\
\hline \multicolumn{7}{|c|}{ Çevresel Kimlik Bileşenleri } \\
\hline \multicolumn{2}{|c|}{ Doğal Çevre } & \multicolumn{5}{|c|}{ Yapay Çevre } \\
\hline Coğrafi & $\begin{array}{l}\text { İklim ve } \\
\text { Bitki Örtüsü }\end{array}$ & Coğrafi & \begin{tabular}{|l|} 
İklim ve \\
Bitki Örtüsü \\
\end{tabular} & Yerle & m Ölçeğ & \\
\hline \multirow[b]{2}{*}{$\begin{array}{l}\text { 1. Eğimli } \\
\text { alanlar, } \\
\text { Sokaklar ve } \\
\text { caddeler } \\
\text { 2. Yitirilmiş } \\
\text { su öğeleri }\end{array}$} & \multirow[b]{2}{*}{$\begin{array}{l}\text { 1. Karadeniz } \\
\text { iklim Özellikleri }\end{array}$} & \multirow[b]{2}{*}{$\begin{array}{l}\text { 1. Topoğrafyanın } \\
\text { Neden olduğu } \\
\text { yokuşlu sokaklar }\end{array}$} & \multirow[b]{2}{*}{$\begin{array}{l}\text { Kale Mahallesinde } \\
\text { Bulunan; } \\
\text { 1. Bedesten çarşısı } \\
\text { gibi alanlarda } \\
\text { Gölgelik olarak } \\
\text { örtü öğesi } \\
\text { 2. Cumhuriyet } \\
\text { Meydanı } \\
\text { yakınlarında } \\
\text { Bulunan Bulvar } \\
\text { AVM'de ahşap } \\
\text { oturma elemanlan }\end{array}$} & $\begin{array}{l}\text { Dokular ve } \\
\text { Bölgeler }\end{array}$ & Sınırlar & $\begin{array}{l}\text { Odaklar ve } \\
\text { işaret Öğeleri }\end{array}$ \\
\hline & & & & \multicolumn{3}{|c|}{$\begin{array}{l}\text { 1. Farklı bölgelerdekifarklı işlevler } \\
\text { Kasaplar Caddesi } \\
\text { - Kuyumcular Sokağı } \\
\text { - } \text { Bedesten Çarşısı } \\
\text { - } \text { Mecidiye Çarşısı } \\
\text { - } \text { Alparslan Sokak } \\
\text { - } \text { Site Merkez Çarşısı } \\
\text { 2. Sınır oluşturan Site Cami, Kuyumcular } \\
\text { Cami, Büyük Cami ve alt geçit } \\
\text { 3. Odaknoktaları ve işaret öğeleri } \\
\text { - Cumhuriyet Meydanı } \\
\text { - Saathane Meydanı } \\
\text { - Büyük Cami } \\
\text { - Site Cami } \\
\text { - Bulvar AVM } \\
\text { - Atatürk Parkı } \\
\text { - Kurtuluş Parkı } \\
\text { - Onur Anıtı - ilkadım Anıtı } \\
\text { - Çınar Ağacı }\end{array}$} \\
\hline
\end{tabular}

Tablo 1. Kale Mahallesi Bölgesi Çevresel Kentsel Kimlik Bileşenleri

\subsection{Toplumsal Kimlik Bileșenleri}

Sosyo-kültürel, sosyo-ekonomik ve somut olmayan kültürel değerleri üzerinden toplumsal kimlik bileşenleri incelenen çalışma alanına;

Sosyo-kültürel çevre bileşenleri açısından bakıldığında, alanın bir ticaret bölgesi olmasından dolayı diğer mahallelere göre barındırdığı yerleşik nüfus sayısı azdır ve bu nedenle gündüz zaman dilimlerinde yoğun gece ise daha az nüfus barındırmaktadır. 2020 TUİK verilerine göre mahallenin yerleşik nüfusu 521 kişidir. 


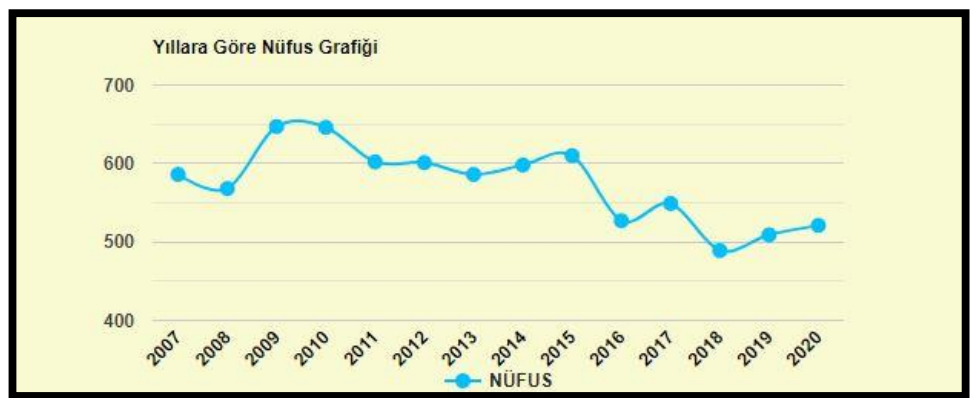

Şekil 19. Kale Mahallesinin TUİK Mahalle Nüfus Verilerince Yıllara Göre Nüfus Grafiği

Tarihsel süreç içerisinde bazı bölgelerinde tarihi dokuda yıpranma görülen mahallenin Saathane meydanı çevresinde gelenekselliğin ve tarihi dokunun daha fazla görüldüğü söylenebilir.

Sosyo-ekonomik çevre bileşenleri incelendiğinde, Samsun kentinin tarihsel gelişiminde önemli olan Kale Mahallesinde yer alan Cumhuriyet Meydanı ve Saathane Meydanı çevresi önemli ticaret merkezi ve odak noktaları konumundadır. Geçmişte de Samsun kentinin ticari açıdan önemli bölgelerinden olan Kale Mahallesi bu özelliğini günümüzde de sürdürmektedir. Bulvar AVM, Bedesten çarşısı, Kuyumcular sokağı, Site Merkez çarşısı, Kasaplar Caddesi ve geleneksel ürünlerin bulunduğu Alparslan sokak gibi alanlardaki üretim ve ticaret sosyo-ekonomik özellikleri göstermektedir [Resim 60-61]. Bölge günümüzde hala düğün alışverişi, kişisel alışveriş ve gastronomi gibi ihtiyaçları karşılamak amacıyla halk tarafından yoğun bir şekilde kullanılmaktadır.
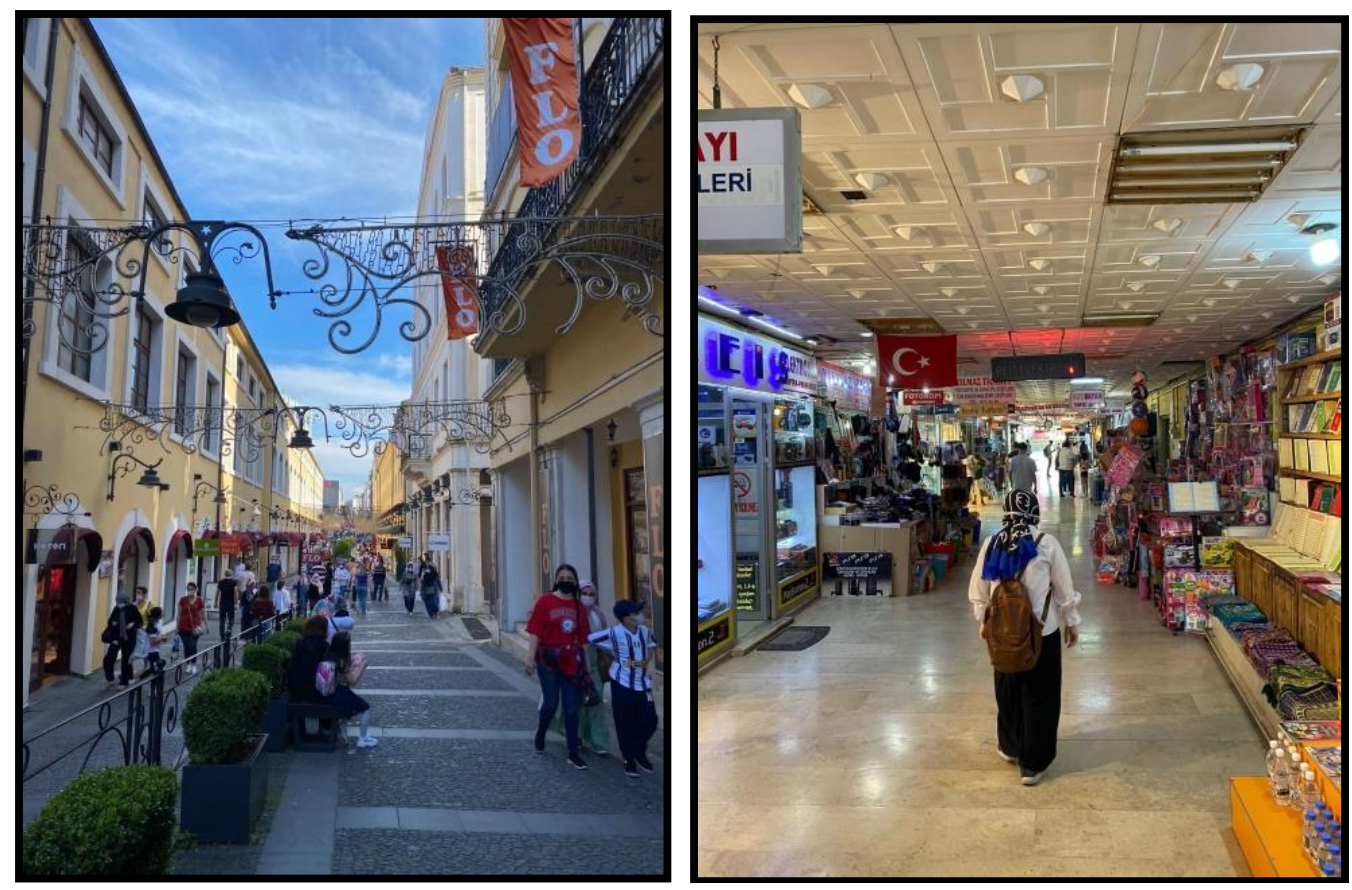

Resim 60-61. Samsun Kale Mahallesi Bulvar AVM-Site Merkez Çarşısı

(Kaynak: Birnur KÖSE, 2021)

Somut olmayan kimlik bileşenlerine bakıldığında ise, gastronomi açısından öne çıkan, yöreye özgü olan Samsun kapalı pide kültürünün baskın olarak yansıtıldığı mekansal alanlar mahalle sınırları içerisinde görülmemektedir [Resim 62]. Ayrıca Samsun simiti ve çarşı alanlarında sık sık satımının yapıldığı döner ve pastanelerde sıkça görülen nokul diğer gastronomik değerler arasındadır [Resim 63-64-65]. 

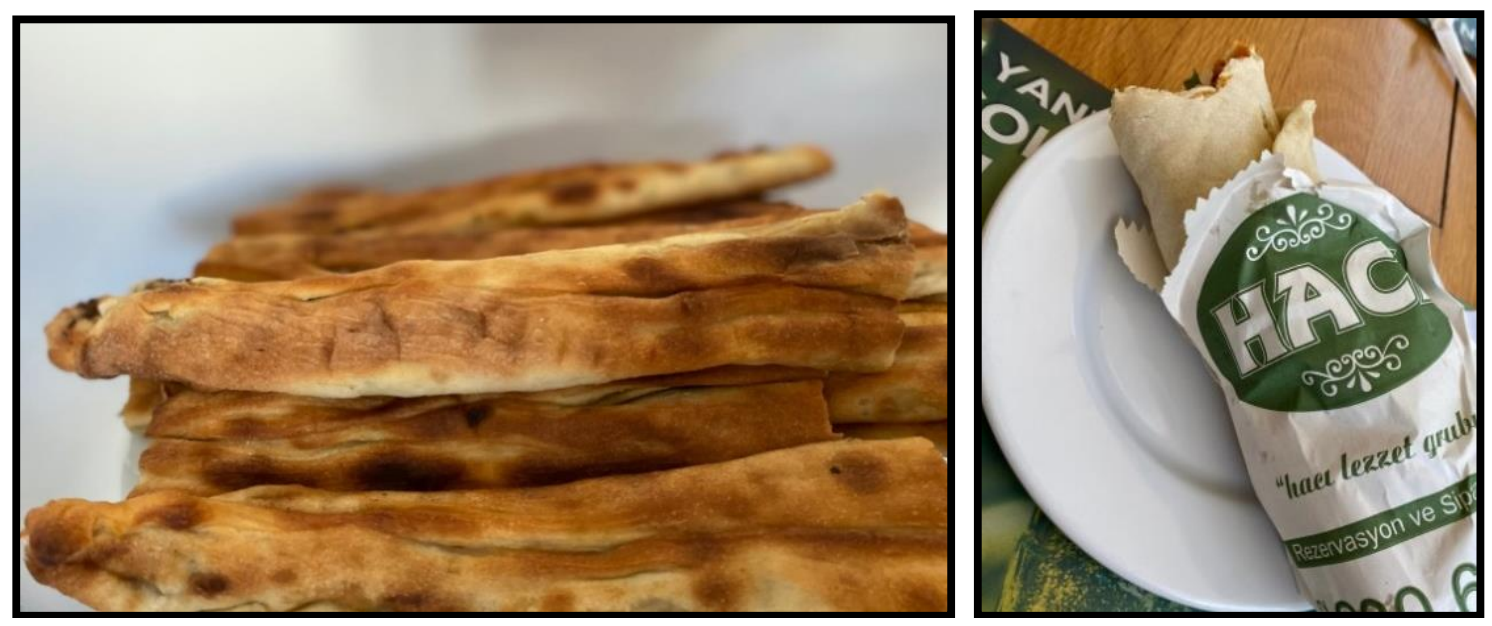

Resim 62-63. Samsun Kapalı Pidesi ve Lavaşa Sarılı Olarak Sunulan Döner (Kaynak: Birnur KÖSE, 2021)
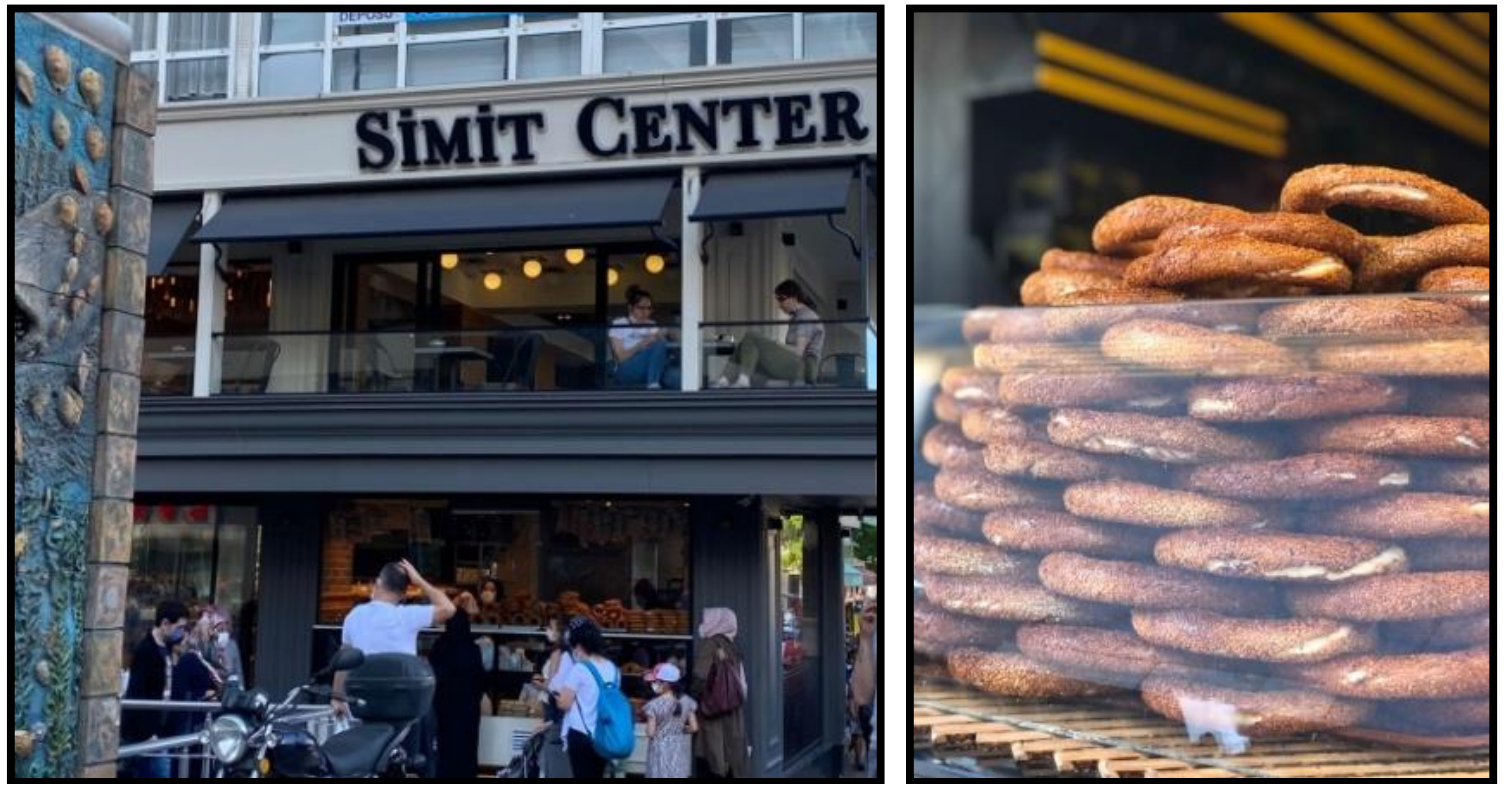

Resim 64-65. Samsun Simiti

(Kaynak: Birnur KÖSE, 2021)

Kültür, sanat ve zanaat açısından, halkın ihtiyaçlarını karşıladığı çok sayıda kuyumcunun bulunduğu kuyumcular çarşısı, Site Merkez çarşısında bulunan geleneksel tesbihçiler, ip, kumaş, boncuk gibi elişi malzemelerinin satıldığı, çeyiz dükkanlarının yer aldığı ve çok sayıda terzinin bulunduğu Şafak Sokak, Afitap Sokak güzergahında bulunan ayakkabı üretimi ve tadilatlarının yapıldığı pasaj ve çok sayıda çay ocağının, çömlekçilerin bulunduğu Namık Kemal Caddesi çalışma alanı içerisinde bulunan geleneksel ve kültürel ihtiyaçları karşılayan ticaret alanlarındandır [Resim 6667-68-69]. 

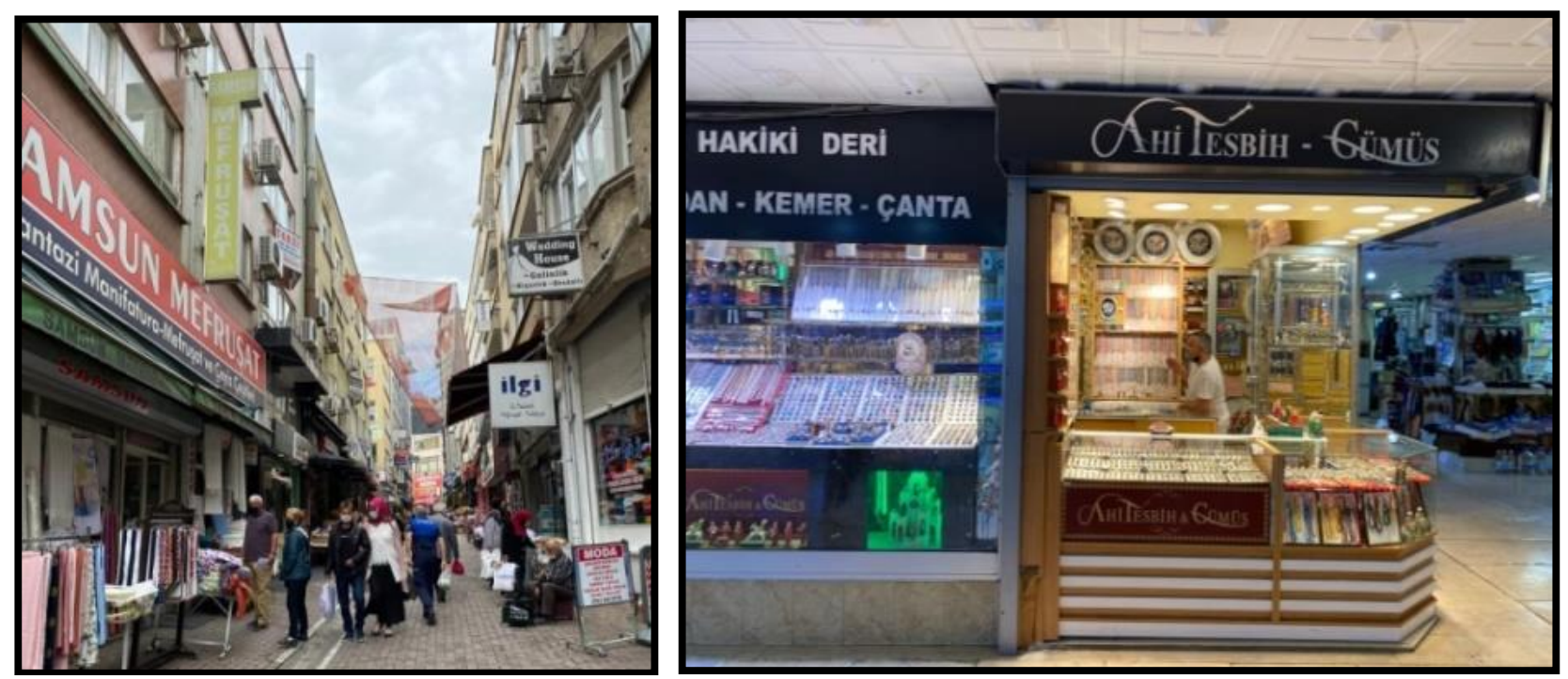

Resim 66-67. Samsun Kale Mahallesi Şafak Sokak - Site Merkez Çaşısı (Kaynak: Birnur KÖSE, 2021)
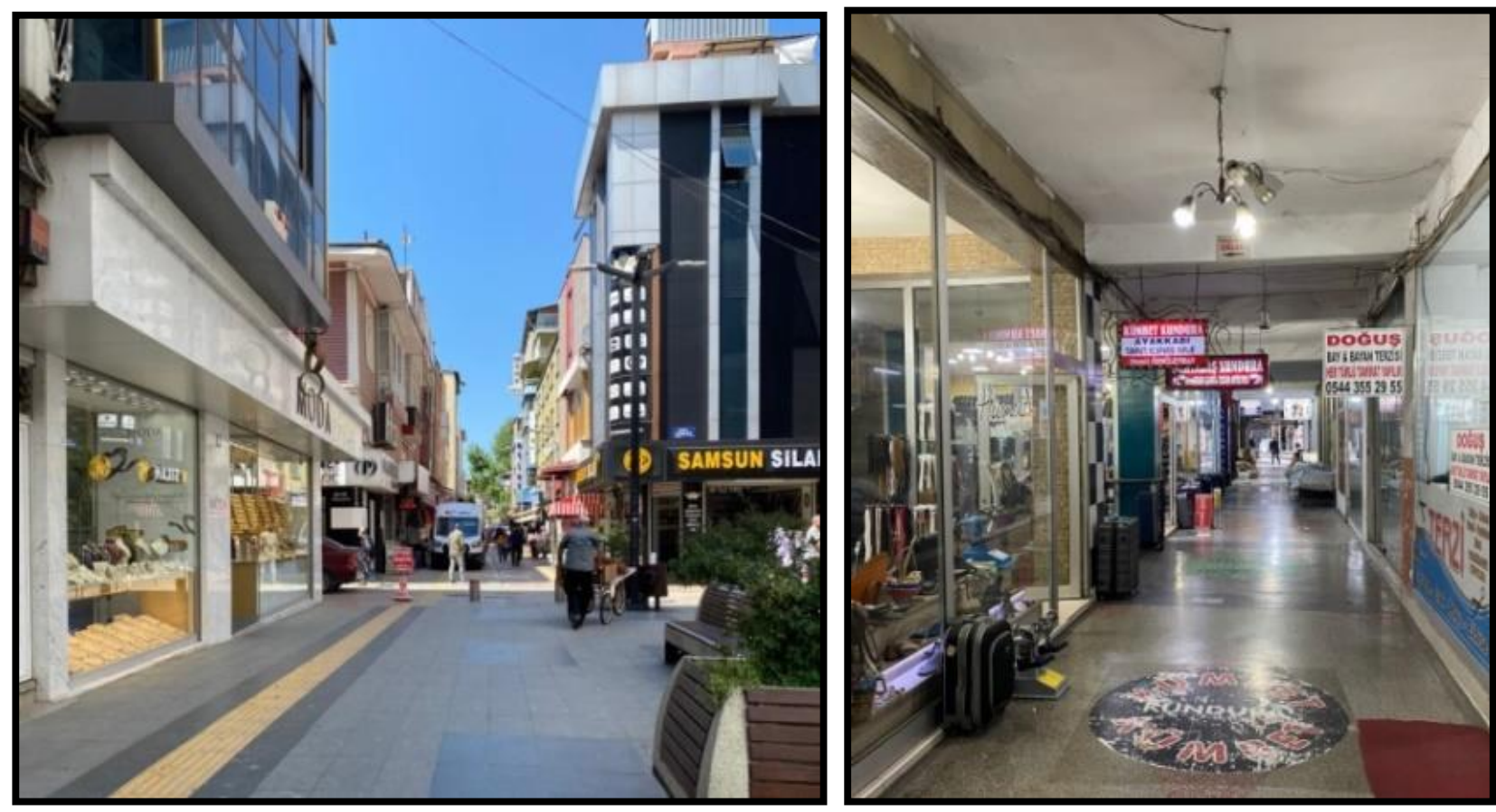

Resim 68-69. Samsun Kale Mahallesi Kuyumcular Çarşısı - Ayakkabıcılar Pasajı (Kaynak: Birnur KÖSE, 2021)

Folklör ve yaşam tarzı açısından bakıldığında, çalışma alanı olan Kale Mahallesinin ticari bir alan olması ve gündüz zaman dilimlerinde geçici nüfus yoğunluğu almasından dolayı herhangi bir folklorik değer yada yaşam tarzı görülmemiştir [Tablo 2]. 


\begin{tabular}{|c|c|c|c|c|c|}
\hline \multicolumn{6}{|c|}{ KENTSEL KIMLİK BİLEŞENLERi } \\
\hline \multicolumn{6}{|c|}{ Toplumsal Kimlik Bileşenleri } \\
\hline \multicolumn{2}{|c|}{ Sosyo-Kültürel Çevre } & \multirow{2}{*}{\begin{tabular}{|c|} 
Sosyo-Ekonomik Çevre \\
İşlevsel Özellikler
\end{tabular}} & \multicolumn{3}{|c|}{ Somut Olmayan Kimlik } \\
\hline $\begin{array}{l}\text { Demoğrafik } \\
\text { Özellikler }\end{array}$ & $\begin{array}{l}\text { Tarihsel } \\
\text { Özellikler }\end{array}$ & & $\begin{array}{l}\text { Kültürel Sanat } \\
\text { Zanaat }\end{array}$ & Gastronomi & \begin{tabular}{|l|} 
Folklör \\
Yaşam Biçimi
\end{tabular} \\
\hline $\begin{array}{l}\text { Yerleşik Nüfus } \\
2020 \text { TUik } \\
\text { verilerine göre } \\
521 \text { kişidir. } \\
\text { Ticaret alanı } \\
\text { olmasından } \\
\text { dolayı gece- } \\
\text { gündüz nüfus } \\
\text { değişikliği } \\
\text { görülmektedir. }\end{array}$ & $\begin{array}{l}\text { Çalışılan alan } \\
\text { içerisinde bazı } \\
\text { bölgelerde tarihi } \\
\text { doku yıpranması } \\
\text { fazla bazı } \\
\text { bölgelerde ise } \\
\text { azdır. } \\
\text { Saathane } \\
\text { Meydanı çevresi } \\
\text { Büyük Cami } \\
\text { Tarihi Bedesten } \\
\text { Alparslan Sokak } \\
\text { geleneksel } \\
\text { ürünlerin } \\
\text { görüldüğü } \\
\text { alanlardır. }\end{array}$ & $\begin{array}{l}\text { Kasaplar Caddesi - gıda } \\
\text { ürünleri, Kuyumcular Sokağı, } \\
\text { Bedesten çarşısı - Yaşlı kesim } \\
\text { giyimi, Mecidiye çarşısı - } \\
\text { Giyim ve ayakkabı, Alparslan } \\
\text { sokak - Geleneksel ürünler, } \\
\text { Bulvar AVM - Yemek yeme, } \\
\text { Site Merkez Çarşısı - Dini } \\
\text { ürünler satışa sunulmaktadır. } \\
\text { Bu üretim ve ticaret sosyo- } \\
\text { ekonomik faktörlerin } \\
\text { göstergesidir. }\end{array}$ & $\begin{array}{l}\text { Ayakkabıcılar } \\
\text { Ceyizciler } \\
\text { Kuyumcular } \\
\text { Çömlekçiler } \\
\text { Çayhaneler } \\
\text { alandaki sanat } \\
\text { ve zanaatı } \\
\text { göstermektedir. }\end{array}$ & $\begin{array}{l}\text { Samsun kapalı } \\
\text { pidesi, } \\
\text { Samsun simiti, } \\
\text { nokul, } \\
\text { döner, } \\
\text { gastronomik } \\
\text { değerlerdir. }\end{array}$ & $\begin{array}{l}\text { Çarşı geleneği } \\
\text { hala devam } \\
\text { eden alanda } \\
\text { ticari alan } \\
\text { olmasından } \\
\text { dolayı herhangi } \\
\text { bir folklorik } \\
\text { değeryada } \\
\text { yaşam tarzı } \\
\text { görülmemiştir. }\end{array}$ \\
\hline
\end{tabular}

Tablo 2. Kale Mahallesi Bölgesi Toplumsal Kentsel Kimlik Bileşenleri

\section{SONUÇ:}

Akkoyunlu (2007) çalıșmasında kent kavramı toplumsal, siyasal, yönetsel ve ekonomik alanların bütün vatandaşlar için var olduğu yaşam alanı olarak tanımlanmıştır. Süreç içerisinde çevresel ve toplumsal değerler bu kentlere bir kimlik yüklemiştir. Kent kimliği sosyal, kültürel ve ekonomik gelişimler doğrultusunda yeniden oluşturulmakta ve tanımlanmaktadır. Bu nedenle sürekli gelişen ve dönüşen kent gibi kent kimliğide dinamik bir kavramdır.

Kent kimliği kavramı çok sayıda çalışmaya konu olmuş ve Eskişehir (İlgar, 2008), Antakya (Kaypak, 2010), Konya (Deniz, 2004; Topçu, 2011), İstanbul (Erkök, 2002; Kutlu vd., 2011), Trabzon (Zorlu vd., 2010; Bayramoğlu \& Özdemir, 2012), Artvin (Turgut vd., 2012), Balıkesir (Güler vd., 2016), Siirt (Aktaş, 2016), İzmit (Ayyıldız ve Ertürk, 2017), Mersin (Ünlü, 2017), Kahramanmaraş (Kısakürek, 2018), Denizli (Erdoğan ve Akay Çorbacioğlu, 2018) kentleri kent kimliği kavramı bakımından değerlendirimiştir. Ancak Samsun ilinin kentsel kimliğini değerlendiren bir çalışma bulunmamaktadır. Bu nedenle kentsel kimlik bileşenleri bakımından değerlendirmek üzere çalışma alanı olarak Samsun kenti belirlenmiştir.

Çalışma Samsun kentinin sahip olduğu kimlik özelliklerini tespit ederek ortaya koymak ve kültürel değerlerinin kent kimliğine olan etkilerinin Kale Mahallesi örneği üzerinden belirlenmesi amacıyla yapılmışıtır.Samsun Kale Mahallesi, önemli odak noktaları olan Cumhuriyet Meydanı ve çevresi, Saathane Meydanı ve çevresi olarak iki bölümde kimlik bileşenleri tespit edilmiş ve ortaya konulmuştur [Tablo 1-2].

Yapılan analizler ve araştırmalar sonucunda çalı̧sma alanı olarak belirlenen Kale Mahallesi ve çevresinin kentin ilk yerleşim bölgelerinden olduğu görülmüştür. Kale Mahallesinin sahip olduğu tarihi dokusu ile Samsun kent kimliğinin oluşmasında oldukça önemli bir yerde olduğu ancak tarihsel süreç içerisinde gerekli önemi görmediği ve bu nedenle günümüzde ticari işlevini hala sürdüren alanın bu süreç içerisinde sahip olduğu değerleri kaybetmeye başladığı görülmektedir.

Bölge fiziksel özellikler açısından değerlendirildiğinde alanda günümüze ulaşabilen çok sayıda tarihi dokudaki yapının bulunduğu söylenebilir. Kentin kimliğini etkileyen somut olmayan değerlere bakıldığında ise bu değerlerin mekana 
aktarımını özellikle alana yüklenen ticari işlevlerde görmek mümkündür. Üzerine yüklenen işlevler doğrultusunda isimlendirildiği görülen sokakların her birinin farklı fonksiyonlara sahip olduğu ve bu alanlarda çarşı geleneğinin hala devam ettirildiği görülmüştür. Ancak alanda bulunan tarihi bedesten gibi bazı geleneksel çarşılarının ise eski ilgiyi görmediği tespit edilmiştir. Aynı zamanda somut olmayan değerlerden olan kentin gastronomisinde önemli yerdeki bölgeye özgü Samsun kapalı pidesi mekanlara yansıtılarak ön plana çıkarılmalıdır. Kentin sahip olduğu bu somut olmayan değerlerin korunması hem bölgeyi hem de kaybedilen değerleri tekrar canlandıracaktır.

Sonuç olarak Samsun Kale Mahallesinin kimliğin oluşmasında etkili olan fiziksel ve işlevsel özelliklerini devam ettirdiği ancak somut olmayan değerlerin yeterince korunamadığı görülmüştür. Bu bağlamda yok olmaya yüz tutmuş bu değerlerin korunması, tekrar hafızalarda canlandırılarak gün yüzüne çıkarılması için çalışma kapsamında tekrar ortaya konulmuştur. Erdoğan ve Akay Çorbacıoğlu (2018) çalışma gibi bu alanda yapıllmış benzer çalışmalara bakıldığında birçok kentin kimliklerini etkileyen değerlerini zaman içerisinde kaybetmeye başladığı görülmüştür.

Aynı zamanda çalışma sonucunda, kent kimliği üzerine Samsun Kale Mahallesinde yapılan görsel analizler ile elde edilen bulgular doğrultusunda öneriler geliştirilmişstir.

- Kent kimliğinin gelişmesi ve sürdürülebilirliği, çevrenin korunması ve kentte yaşayan toplumun aidiyet duygusunu arttırmak açısından yapay çevrenin doğal çevre ile bütünleştirilmesi gerekmektedir.

- Kent kimliği açısından önemli bir yerde olan rekreasyon alanları da doğru noktalarda ihtiyaçları karşılayacak biçimde oluşturulmalıdır.

- Kentlerin özgün gastronomik değerlerinin sürdürülebilirliği ve kent kimliğine katk1 sağlayabilmesi için bu değerlerin mekanlara yansıtılması gerekmektedir.

- Süreç içerisinde önemini yitiren, tarihi dokuya sahip alanlarda uygun düzenlemeler ile yeniden canlandırma uygulamaları yapılmalıdır.

- Kentlerin sahip olduğu tarihi geçmişe sahip yapıların yenilenme uygulamalarının doğru bir şekilde yapılması aynı zamanda yeni yapılacak olan yapılarında dokuya uygun olarak tasarlanması ayrıca önem taşımaktadır.

$\mathrm{Bu}$ doğrultuda kent kimliğinin gelişiminde mimar, şehir ve bölge planlamacı gibi çeşitli meslek gruplarına büyük rol düşmektedir.

\section{Etik Standart ile Uyumluluk}

Çıkar Çatışması: Yazarlar herhangi bir çıkar çatışmasının olmadığını beyan eder.

Etik Kurul İzni: Bu çalışma için etik kurul iznine gerek yoktur

Finansal Destek: Yoktur.

\section{KAYNAKÇA:}

Akkoyunlu, K., (2007). "Sürdürülebilir Kent", Kent ve Politika: Antik Kentten Dünya Kentine, Der: Ayşegül Mengi, İmge Yayınevi, Ankara.

Aktaş, A., (2016). "Göç ve Modernleşme Bağlamında Siit’te Değişsen Kent Kimliği", Siirt Üniversitesi İlahiyat Fakültesi Dergisi, Cilt: 3, Sayı:2., s. 79-100.

Alevkayalı, A., Uzun A., (2020). '’Kent Kimliği Oluşmasında Üniversite Öğrencileri-Yerel Halk İlişkisi: Balıkesir Üniversitesi/Kenti Örneği’, Van Yüzüncü Yıl Üniversitesi Sosyal Bilimler Enstitüsü Dergisi, Sayı: 47 Sayfa: 281-302. 
Alver, K., (2012). "Kent İmgesi" Kent Sosyolojisi, Hece Yayınları, s. 9-31.

Ayyıldız, S., \& Ertürk, F. (2017). "Kentsel Kimlik Bileşenleri İle Yerel Kimliğin İzlerini Sürmek: Kapanca Sokak Örneği", Journal of Architectural, 2(1), 65-88.

Bayramoğlu, E., \& Özdemir, B. (2012). "Trabzon kent merkezi, uzun sokak kentsel donatı elemanlarının kent kimliği açısından değerlendirilmesi", Kastamonu Üniversitesi, Orman Fakültesi Dergisi, 12(2), 182-191.

Birol, G., (2007). "Bir Kentin Kimliği ve Kervansaray Oteli Üzerine Bir Değerlendirme”, Arkitekt Dergisi, sayı: 514, s. $46-54$.

Boussaa, D., (2018). "Urban Regeneration And The Search For İdentity İn Historic Cities", Sustainability, 10(1), 48.

Deniz, K., (2004). Konya'da farklı üç kentsel mekanda kent kimliği üzerine bir araştırma, Selçuk Üniversitesi, Fen Bilimleri Enstitüsü, Doktora Tezi, Konya.

Dönmez, Y., Öztürk, M., Gökyer, E., Türkmen, F., \& Türk-Kazak, H. A. Y. U. (2017). "Korunan Alanlarda Koruma Kurullarının Turizme Olan Etkileri: Safranbolu Örneği", Proceedıngs Book, 778.

Erdoğan, G., Akay Çorbacıoğlu S., (2018). "Denizli Kent Kimliği Bileşenleri", Kent Akademisi, 11 (33), Issue 3, Sayfa, 459-473.

Erkök, F. (2002). "Kentsel Bileşenleri Ve Kıyı Kenti Kimliği Bağlamında İstanbul'un Öznel Ve Nesnel Değerlendirmesi", İstanbul Teknik Üniversitesi, Fen Bilimleri Enstitüsü, Doktora Tezi, İstanbul.

Güler, T., Şahnagil, S., Güler, H., (2016). "Kent Kimliğinin Oluşturulmasında Kültürel Unsurların Önemi: Balıkesir Üzerine Bir İnceleme", Paradoks Ekonomi, Sosyoloji ve Politika Dergisi, Cilt:12, ÖzelSayı.

Günaydın, A.S., Altunkasa, M.F., (2019). "Tarihi Kent Merkezlerinin Koruma Ve Geliştirme Stratejilerinin Belirlenmesi: Gaziantep Örneği", Bingöl Üniversitesi Sosyal Bilimler Enstitüsü Dergisi, Cilt: 9, Sayı: 17.

Hayta, Y., (2016). “Kent Kültürü ve Değişen Kent Kavramı“, Bitlis Eren Üniversitesi Sosyal Bilimler Enstitüsü Dergisi / Journal of Bitlis Eren University Institute of Social Sciences, Cilt/volume:5 • Say1/Number:2, ss.165-184.

İlgar, E., (2008). "Kent kimliği ve kentsel değişimin kent kimliği boyutu: Eskişehir Örneği", Anadolu Üniversitesi Fen Bilimleri Enstitüsü Mimarlık Ana Bilim Dalı, Yüksek Lisans Tezi.

Ismep, (2014), "Kültürel Mirasin Korunması", http://www.Guvenliyasam.Org/WpContent/Uploads/2016/02/Kulturel.Pdf.

Kaypak, Ş., (2010). "Antakya'nın Kent Kimliği Açısından İrdelenmesi", Mustafa Kemal Üniversitesi Sosyal Bilimler Enstitüsü Dergisi, Cilt: 7, Say1: 14, s. 373 - 392.

Keleş, R., (2005). "Kültür Üzerine", Mülkiye Dergisi, Cilt: 29, Sayı: 246.

Kiper P., (2006), "Kent Kimliğinin Korunmasında Planlamanın Rolü",

http://21inciyuzyilicinplanlama.org/wpcontent/uploads/2016/08/Perihan-Kiper

Kısakürek, Ş., \& Bayazıt, E., (2018). "Kahramanmaraş Kenti Örneği’nde Kent Kimliği ve Kentsel Donatı Elemanları", Turkish Journal of Forest Science, 2(1), 49-59.

Koçak, H., (2011). "Kent-Kültür İlişkisi Bağlamında Türkiye’de Değişen ve Dönüşen Kentler", Sosyal Bilimler Araştırmaları Dergisi. II, ss.259-269.

Kodal G., \& Demirel, Ö., (2014). "Trabzon Kenti Ortahisar Bölgesi Tarihi Aksının Kent Kimlik Bileşenleri Açısından Değerlendirilmesi", Uluslararası Hakemli Tasarım ve Mimarlık Dergisi, 1(1). 
Koyuncu, A., (2013). "Kimliğin İnşasında Kent: Konya Örneği", Akademik İncelemeler Dergisi (Journal of Academic Inquiries) Cilt/Volume: 8, Say1/Number: 2.

Kökten, K., Özgüç, N., Özgüç, T., (1945). “1940-1941 Yılında Türk Tarih Kurumu Adına Yapılan Samsun Bölgesi Kazılarını Hakında İlk Kısa Rapor”, Belleten, Sayı: IX/35, s. 361-400.

Kutlu, R., Manav, B., \& Ertürk, Z. (2011). İstanbul Kıyı Mimarisinin Görsel Matris Üzerinden Kimlik İncelemesi, The Turkish Online Journal of Design Art and Communication, 1(2).

Lynch K., 1961, The Image of the City, MIT Press,Cambridge, MA (1961).

Negiz, N., (2017). "Kentlerin Tarihsel Sürdürülebilirliğinde Kültürel Miras: Önemi ve Değeri Üzerine Düşünmek", Akademia Sosyal Bilimler Dergisi, 3(1), 159-172.

Oğan, O., Yasak, Ü. (2020). Küreselleşme bağlamında mekansal kent kimliği ve markalaşmanın kent turizmine etkisi. Türk Coğrafya Dergisi, (74), 97-105.

Oğurlu, İ., (2014). "Çevre-kent imaj1-kent kimliği-kent kültürü etkileşimlerine bir bakış", İstanbul Ticaret Üniversitesi Fen Bilimleri Dergisi, Y11: 13 Sayı: 26 Güz 2014 s. 275-293.

Ouf, T.A., Makram, A., (2019). "An Approach to Improve Quality of Life and Sustainability in the Centers of Old Cities", Journal of Civil Engineering and Architecture, 461-468.

Ozturk, S., Isinkaralar. O. ve Ayan, E. (2018a). Visibility Analysis in Historical Environments: The case of Kastamonu Castle and its Surrounding. Journal of Current Researches on Social Sciences, 8 (4), 405-412.

Ozturk, S., Ayan, E. ve Isinkaralar O., (2018b). "Visual Landscape Evaluation of Kastamonu Clock Tower Environment as a Historical urban Area," Fresenius Environmental Bulletin, 27(12B), 9617-9625.

Ozturk, S., Ayan, E. ve Isinkaralar O., (2018c). "Kentsel İmgelerin Görsel Açıdan Değerlendirilmesi, Samsun Amisos Örneği", Turan Stratejik Araştırmalar Merkezi,, 10 (40), 428-431, Aralık.

Öztürk S., Işınkaralar Ö., Çiçek E., Vural Ö. ve Meydan K. (2020b). "Kentsel Donatı Elemanlarının Kent Kimliği Açısından Değerlendirilmesi: Safranbolu Örneği", Uluslararası Sosyal Araştırmalar Dergisi, 69 (13), 667-677.

Öztürk, S, Işınkaralar, Ö, Yılmaz, D, İhtiyar, M. (2020a). "Koruma Yaklaşımı Olarak Tarihi Bir Güzergâhın Kültür Rotasına Dönüştürülmesi: Kastamonu Örneği", Turar Turizm ve Araştırma Dergisi, 9 (2), 144-159.

Öztürk, S., Işınkaralar, Ö., Yılmaz, D., (2021), "Restorasyon çalışmaları sonrası yerel halkın algı ve tutumları (Kayseri kalesi örneği)", Doğu Coğrafya Dergisi 26(45), 183-194.

Perihan, M., Aşur, F. (2020). "Tarihi Kentsel Peyzaj ve Kent Kimliği İlişkisi", Kent Akademisi, 13(1), 163-175.

Riza M., Doratli N., Fasli M., (2012). "City Branding and Identity", Procedia - Social and Behavioral Sciences, 35: 293 -300 .

Sağlık, E., Kelkit, A., (2019). "Kentsel Kimlik Bileşenlerinin Kent Kullanıııları Tarafından Belirlenmesi: Örnek Kent Çanakkale", Çanakkale Onsekiz Mart Üniversitesi Fen Bilimleri Enstitüsü Dergisi, 63-79.

Samsun İl Kültür ve Turizm Müdürlüğü Fotoğraf Arşivi.

Samsun Valiliği İl Özel İdaresi, (2012). "Taşınmaz Kültür Varlıkları Envanteri", Samsun Valiliğgi Yayınları, Samsun.

Sarısakal, B., (2002). "Bir Kentin Tarihi Samsun", Büyükşehir Belediyesi Yayınları, Samsun.

SEZIK, M., (2018). "Kentlerin Tarihi ve Kültürel Dokusunun Korunması Bağlamında Kentsel Dönüşüm Uygulamaları", Kent Akademisi, Volume, 11 (36), Issue 4, Pages, 600-608. 
Şendil, G. N., (2017). “Kent kimliği: Safranbolu örneği“, Master's thesis, Uludağ Üniversitesi.

Tekeli, İ., (1991). “Bir Kentin Kimliği Üzerine Düşünceler”, Kent Planlaması Konuşmaları, Ankara:TMMOB Mimarlar Odas1 Yayını, s. 79-89.

Topçu, K., (2011). "Kent kimliği üzerine bir araştırma: Konya örneği", Uluslararası İnsan Bilimleri Dergisi, 8(2), 10491072.

Turgut, H., Özalp, A. Y., \& Erdoğan, A., (2012). "Artvin ilinde doğal çevrenin kent kimliğine etkileri", Turkish Journal of Forestry, 13(2), 172-180.

Tüfekçioğlu, A., Boran, A. (2004). Kitabelerin Diliyle Samsun Kalesi ve İç Kale Mescidi.

Uzuneminoğlu, H., (1993). "Şehirlerin Alan Bakımından Gelişmesi ve Samsun Örneği", Ondokuz Mayıs Üniversitesi Eğitim Fakültesi Dergisi, 8(1), 273-290.

Ünügür, M., (1996). "İstanbul'un Değişen Kentsel Kimliği Üzerine", Arkitekt Dergisi, 444, Say1: 12, İstanbul, 42-49.

Yılmaz, A., Gül S., (2018). 'Samsun Şehrinde Tarihî Yapı Mirasi Ve Şehirsel Koruma', Osmanlı Mirası Araştırmaları Dergisi (OMAD), Cilt 5, Sayı 13, ss. 49-67.

Yılmaz, C., (2011). "Samsun Şehri; Kuruluş Yeri, Nüfus ve Kentsel Gelişim Özellikleri".

Zorlu, T., Aydıntan, E., \& Engin, E. (2010). "Kent Kimliği: Tanjant ve Karadeniz Sahil Yollarının Trabzon Kent Kimliğine Etkileri", Mimarlık Dergisi, 352.

URL1, 2021 https://www.samsun.bel.tr/album/samsundan-fotograflar-12 Erişim tarihi: 20.05.2021

URL2, 2021 https://www.atlasbig.com/tr/samsunun-mahalleleri Erişim tarihi: 20.05.2021

URL3, 2021 https://www.ilkadim.bel.tr/mahalledetay/kale-mahallesi Erişim tarihi: 20.05.2021 